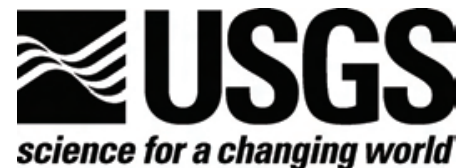

\title{
Preliminary Assessment of Volcanic and Hydrothermal Hazards in Yellowstone National Park and Vicinity
}

By Robert L. Christiansen, Jacob B. Lowenstern, Robert B. Smith, Henry Heasler, Lisa A. Morgan, Manuel Nathenson, Larry G. Mastin, L. J. Patrick Muffler, and Joel E. Robinson

Open-file Report 2007-1071

U.S. Department of the Interior

U.S. Geological Survey 


\section{U.S. Department of the Interior \\ DIRK KEMPTHORNE, Secretary}

\section{U.S. Geological Survey \\ Mark D. Myers, Director}

U.S. Geological Survey, Reston, Virginia 2007

For product and ordering information:

World Wide Web: http://www.usgs.gov/pubprod

Telephone: 1-888-ASK-USGS

For more information on the USGS - the Federal source for science about the Earth,

its natural and living resources, natural hazards, and the environment:

World Wide Web: http://www.usgs.gov

Telephone: 1-888-ASK-USGS

Suggested citation:

Christiansen, R. L., Lowenstern, J. B., Smith, R. B., Heasler, H., Morgan, L. A., Nathenson, M., Mastin, L. G., Muffler, L. J. P., and Robinson, J. E., 2007, Preliminary assessment of volcanic and hydrothermal hazards in Yellowstone National Park and vicinity: U.S. Geological Survey Open-file Report 2007-1071, 94 p.

Any use of trade, product, or firm names is for descriptive purposes only and does not imply endorsement by the U.S. Government.

Although this report is in the public domain, permission must be secured from the individual copyright owners to reproduce any copyrighted material contained within this report. 


\section{Contents}

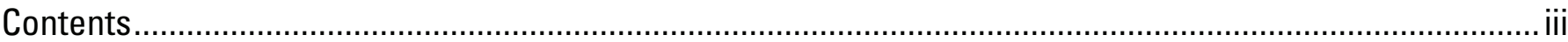

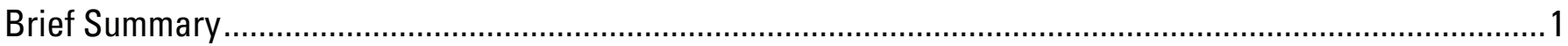

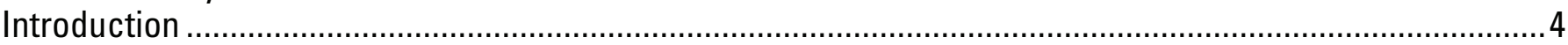

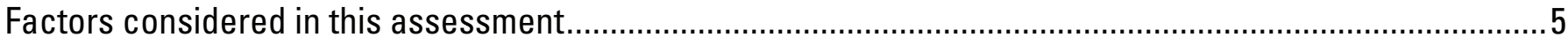

Current State of the Yellowstone system .......................................................................................

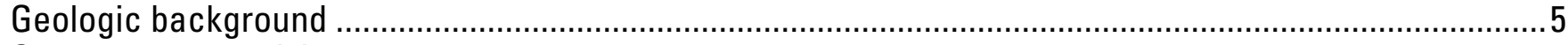

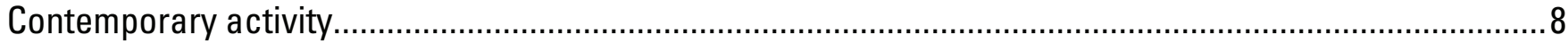

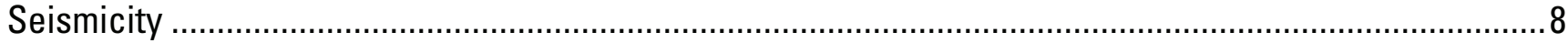

Crustal deformation

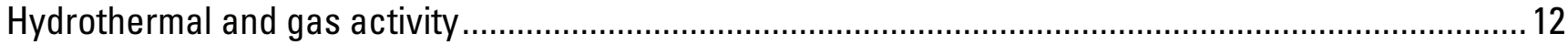

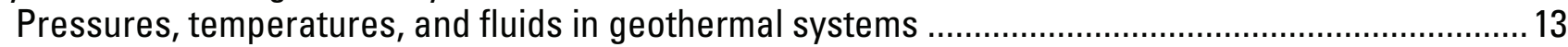

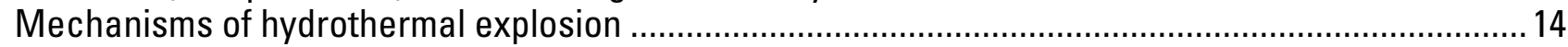

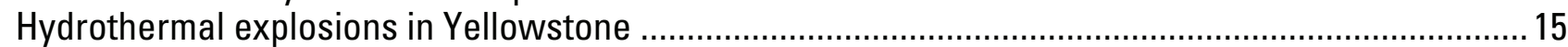

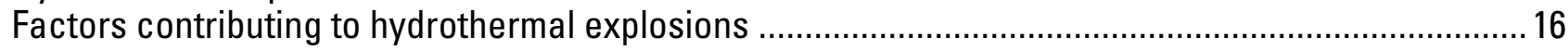

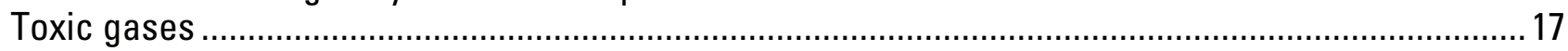

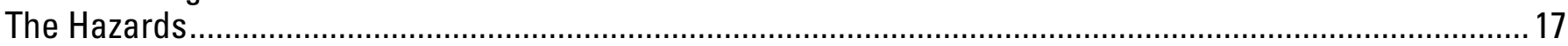

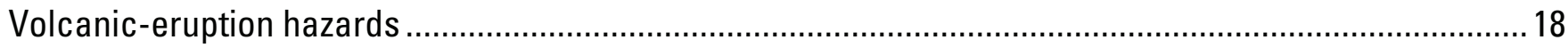

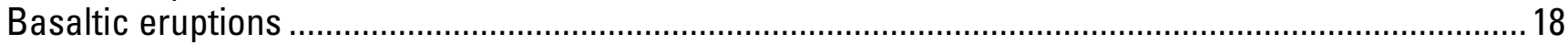

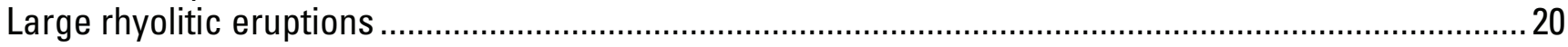

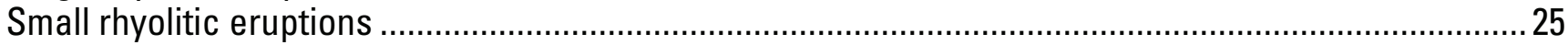

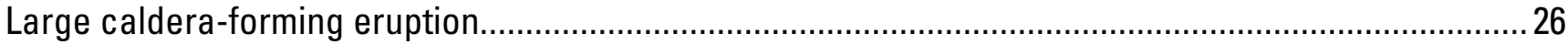

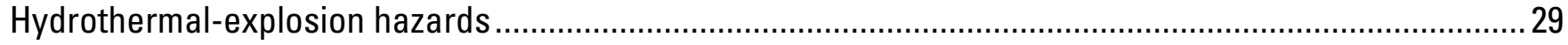

How often do they occur?

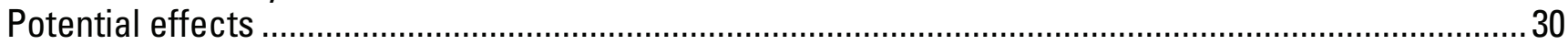

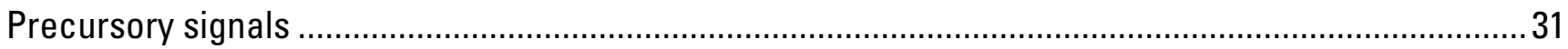

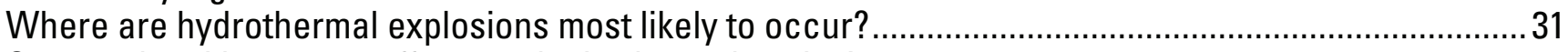

Seasonal and long-term effects on hydrothermal explosions ............................................................ 33

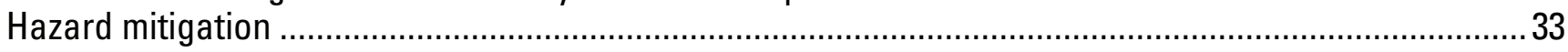

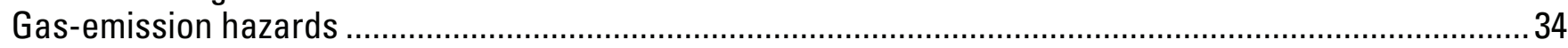

Relevant examples of toxic volcanic or hydrothermal gas hazards ..................................................... 35

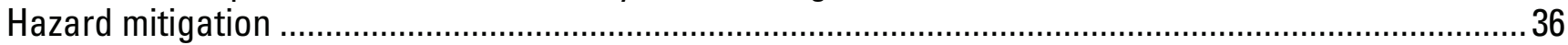

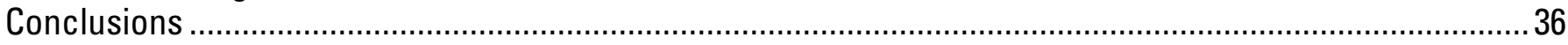

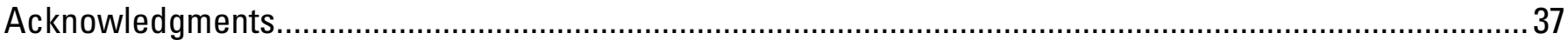

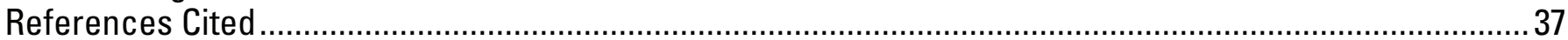

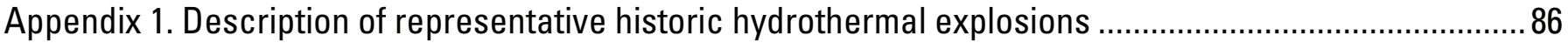

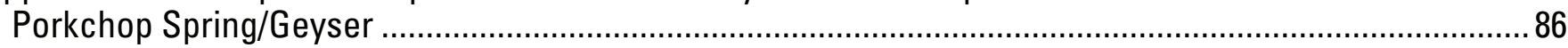

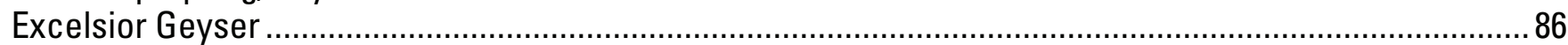

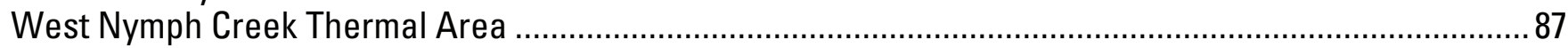

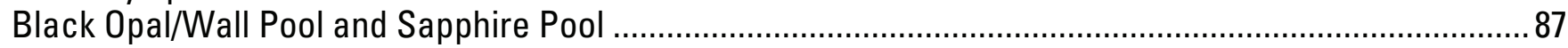

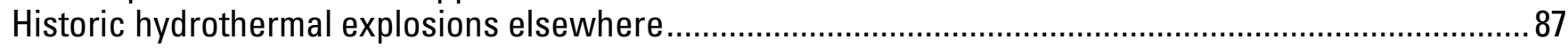

Appendix 2. Description of large prehistoric hydrothermal eruption sites at Yellowstone ..............................8 88

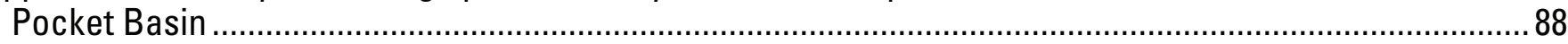

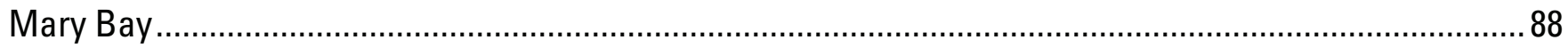

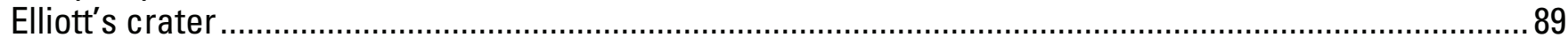

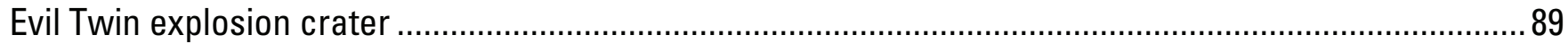

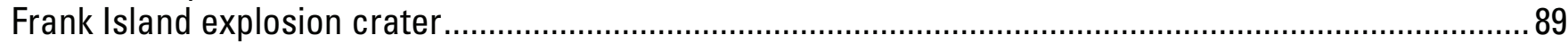

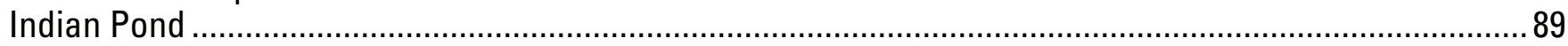

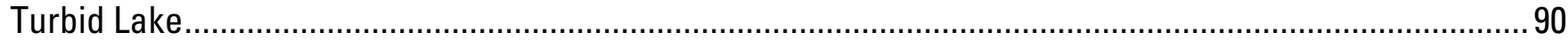


Appendix 3. Probabilities of episodic volcanic eruptions and application to the young intracaldera volcanic history of Yellowstone... 


\title{
Preliminary Assessment of Volcanic and Hydrothermal Hazards in Yellowstone National Park and Vicinity
}

\author{
By Robert L. Christiansen', Jacob B. Lowenstern1, Robert B. Smith², Henry Heasler ${ }^{3}$, Lisa A.
} Morgan', Manuel Nathenson', Larry G. Mastin', L. J. Patrick Muffler ${ }^{1}$, and Joel E. Robinson ${ }^{1}$

\section{Brief Summary}

Possible future violent events in the active hydrothermal, magmatic, and tectonic system of Yellowstone National Park pose potential hazards to park visitors and infrastructure. Most of the national park and vicinity are sparsely populated, but significant numbers of people as well as park resources could nevertheless be at risk from these hazards. Depending on the nature and magnitude of a particular hazardous event and the particular time and season when it might occur, 70,000 to more than 100,000 persons could be affected; the most violent events could affect a broader region or even continent-wide areas. This assessment of such hazards is presented both as a guide for future activities of the Yellowstone Volcano Observatory (YVO) and to aid appropriate response planning by the National Park Service and surrounding agencies and communities. Although the assessment is presented here in some technical detail, this summary is intended to be understandable to non-scientists. The principal conclusions also will be made available in other forms, more accessible to general readers.

The Yellowstone Plateau was built by one of Earth's largest young volcanic systems, having episodically erupted great volumes of both lava and explosively ejected pumiceous ash for more than 2 million years. These eruptive materials are products of two compositional types of subsurface magma: basaltic magma is relatively fluid and, in this setting, generally produces small to moderate volumes of lava in relatively brief eruptions; rhyolitic magma is more viscous and either can erupt effusively to produce small to large volumes of lava or explosively to produce coarse pumice and finer ash. The three largest Yellowstone eruptions produced blanketing deposits of rhyolitic ash so hot that they welded into sheets of dense rock covering large areas, extending beyond the national park. Each of them also produced a rain of ash that spread over much of western and central North America and beyond; these ash deposits are greater than $2 \mathrm{~m}$ thick near their eruptive sources and as much as a meter thick in surrounding areas. Each of these three eruptions produced a caldera, or deep crater-like depression, tens of kilometers wide, formed by collapse of the ground surface into a partly emptied subterranean magma chamber. The latest of these three great eruptions formed the Yellowstone caldera. Renewed rhyolitic magma influx beneath the Yellowstone caldera in central Yellowstone National Park uplifted parts of the caldera floor and produced voluminous intracaldera lavas, the youngest of which extruded in a series of eruptive episodes about 164,000, 152,000, 114,000, 102,000, and 72,000 years ago. During the same span of time, generally smaller flows of both basalt and rhyolite have erupted in several areas outside the Yellowstone caldera: (1) northwest of the caldera, (2) near the southern boundary of the

\footnotetext{
${ }^{1}$ U.S. Geological Survey

${ }^{2}$ University of Utah

${ }^{3}$ National Park Service
} 
park, (3) in the basin of Island Park, west of Yellowstone National Park, and (4) especially in the southern part of a corridor between Norris Geyser Basin and Mammoth Hot Springs.

Disruption of the Earth's surface by faulting and regional uplift characterize the geologic framework of Yellowstone Plateau volcanism. Some of the regional faults that bound the mountain ranges around the Yellowstone Plateau are capable of producing large-magnitude $(M>7)$ earthquakes. In contrast, faults within the caldera are mainly small, produce smaller-magnitude $(\mathrm{M} \leq 6.8)$, relatively shallow earthquakes, and reflect strains in the Earth's crust associated with magmatic intrusion and hydrothermal activity. Swarms of generally small earthquakes occurring within localized areas over restricted periods of time characterize much of the earthquake activity within and adjacent to the Yellowstone caldera. This seismicity is monitored by a network of seismographs within and adjacent to the park and is recorded and processed nearly in real time at the University of Utah as part of the YVO program and archived as a contribution to the U.S. Geological Survey (USGS) Advanced National Seismic System database.

Leveling surveys, satellite-based measurements, and geologic studies of former shorelines of Yellowstone Lake all show that the entire area of the Yellowstone caldera and a seismically active zone to the northwest undergo episodes of ground uplift and subsidence, sometimes encompassing the entire caldera and sometimes in more local and complex patterns of both uplift and subsidence. Such deformation in the Yellowstone region is monitored by YVO mainly through a network of continuously recorded Global Positioning System (GPS) receivers recorded at the University of Utah. The GPS data are incorporated as part of the National Science Foundation's EarthScope Plate Boundary Observatory, archived at UNAVCO and available through the YVO website (http://volcanoes.usgs.gov/yvo/index.html).

The active hydrothermal system of Yellowstone National Park is one of the largest on Earth. Although accidents involving hot water injure Yellowstone visitors from time to time, conformance with normal Park Service procedures and regulations would ordinarily be sufficient to prevent most of them. By contrast, a commonly recurring, more acute hazard at Yellowstone is the explosive ejection of steam, water, and rock with no associated volcanism. These hydrothermal explosions are caused by hot subsurface waters that flash to steam, breaking the overlying rocks that confine them and ejecting the debris to form a crater. It is generally not clear just what triggers these events, but possible triggers include strong local earthquakes, seasonal or long-term declines in ground water levels, and changes in the underground distribution of heat. Many hydrothermal explosions have few if any premonitory indications.

At least 26 hydrothermal explosions have been documented in the 126-year historic record of the national park, and others undoubtedly escaped observation. Since the Yellowstone Plateau was last glaciated, ending about 16,000 years ago, at least 18 large hydrothermal explosions have formed craters wider than $100 \mathrm{~m}$. Conservatively, at least one rock-hurling explosion every two years is estimated to occur at Yellowstone, but because most of these events are small and usually occur when few visitors are present, the likelihood of harm to park visitors is relatively small. The average recurrence of an explosion that could cause personal injury is probably between 10 and 100 years. Average recurrence time of an explosion large enough to produce a $100-\mathrm{m}$-diameter crater is probably about 200 years, but such an event could expel rocks and other hot debris more than $2 \mathrm{~km}$ from the explosion site. Most hydrothermal-explosion craters at Yellowstone are in the Firehole River geyser basins, beneath or around Yellowstone Lake, and in the southern part of the NorrisMammoth Corridor.

In addition to hydrothermal explosions, toxic gases-mainly carbon dioxide and hydrogen sulfide-pose hazards. Concentrations of these gases in the atmosphere are generally low at Yellowstone, but they can build up in confined areas such as valleys, caves, and tunnels, especially during windless conditions. Most areas with toxic-gas hazards can be kept off-limits to people, but gas emissions should continue to be monitored. 
No volcanic eruption has occurred in Yellowstone National Park or vicinity in the last 70,000 years or more. Nevertheless, several types of volcanic eruption hazards are possible in the future.

Basaltic lavas have erupted around the margins of the Yellowstone Plateau volcanic field throughout its evolution. These relatively low-viscosity lavas generally erupt rapidly, most eruptions lasting no more than a few weeks to a few months though the largest flow fields may accumulate in multiple eruptions lasting months to years. The average period between basaltic eruptions in the Yellowstone region since formation of the Yellowstone caldera has been about 16,000 years. The most likely location of a future basaltic eruption is within the basin of Island Park, west of Yellowstone, but basalts could erupt anywhere in a 40-km-wide band around the caldera. Future basaltic eruptions could cover several square kilometers with lava up to tens of meters thick. Basaltic ash and cinders also might blanket hundreds of square kilometers to depths of a few meters to a few centimeters, and if a vent emerged beneath water or saturated ground, more explosive eruptions could cause significant destruction, such as blasting down trees or structures.

Large rhyolitic lava flows, many having volumes greater than $10 \mathrm{~km}^{3}$, have erupted within the Yellowstone caldera during the past 170,000 years. Initially these larger eruptions were preceded by explosively ejected pumice and ash. In a similar future eruption, ejecta could bury broad areas, locally to many meters. Subsequent lava extrusion could last for years, covering areas as great as $350-400 \mathrm{~km}^{2}$ to thicknesses of tens or hundreds of meters and volumes of 5 to more than $50 \mathrm{~km}^{3}$. Because such voluminous rhyolitic lava eruptions have not been observed anywhere in historical time, it is uncertain how long such an event might continue; extrusion might be orders of magnitude faster than for smaller flows. The probability of a future large intracaldera rhyolitic eruption is difficult to estimate. Available data suggest a highly episodic behavior of past eruptions of this sort, periods of a few thousand years characterized by numerous eruptions being separated by longer intervals of about 12,000 to 38,000 years without eruption. One statistical measure of eruption probabilities based on this episodic behavior suggests an average recurrence of 20,000 years. The fact that no such eruption has occurred for more than 70,000 years may mean that insufficient eruptible magma remains beneath the Yellowstone caldera to produce another largevolume lava flow.

Small rhyolitic lava flows postdating the Yellowstone caldera have erupted mainly north of the caldera, but one such flow also lies near the South Entrance to the park. Two distinct types of primary hazards might be associated with small rhyolitic eruptions at Yellowstone. Just as for larger rhyolitic lava eruptions, initial venting almost certainly would explosively eject rhyolitic pumice; the coarser fragments would fall back close to the vent, but finer pumiceous ash would enter the atmosphere and fall downwind for many kilometers. Structures, power lines, etc. could be damaged by ash loading, especially if eruption were accompanied by heavy rain. The initial explosive eruptions could last a few hours to several weeks and be followed by viscous extrusion of rhyolitic lava, covering several square kilometers to tens of meters thick; lava could continue to extrude for many months or even years. Viscous rhyolitic lava would advance much more slowly than a basaltic flow; most affected facilities could be safely evacuated and perhaps relocated. The average recurrence period of small extracaldera rhyolitic eruptions in the Yellowstone Plateau volcanic field is about 50,000 years.

In addition to the primary hazards posed by any future eruption of basalt or a small or large rhyolitic lava eruption, important possible secondary consequences include wildland fires, debris flows, and floods triggered by the displacement of surface drainages by lava.

Systematic seismic, deformation, and hydrothermal monitoring by YVO is likely to provide indicators of any impending volcanic eruptive activity in Yellowstone National Park. Premonitory events detected by such monitoring might include multiple shallow earthquake swarms of 
increasing frequency and intensity, the ground vibrations called volcanic tremor, localized uplift of the surface, ground cracks, and anomalous gas emissions.

Of all the possible hazards from a future volcanic eruption in the Yellowstone region, by far the least likely would be another explosive caldera-forming eruption of great volumes of rhyolitic ash. Abundant evidence indicates that hot magma continues to exist beneath Yellowstone, but it is uncertain how much of it remains liquid, how well the liquid is interconnected, and thus how much remains eruptible. Any eruption of sufficient volume to form a new caldera probably would occur only from within the present Yellowstone caldera, and the history of postcaldera rhyolitic eruptions strongly suggests that the subcaldera magma chamber is now a largely crystallized mush. The probability of another major caldera-forming Yellowstone eruption, in the absence of strong premonitory indications of major magmatic intrusion and degassing beneath a large area of the caldera, can be considered to be below the threshold of useful calculation.

\section{Introduction}

Yellowstone National Park, justly famous for its unmatched geysers, diverse wildlife, and uniquely preserved ecologic communities, also encompasses one of Earth's largest systems of volcanic, seismic, and hydrothermal activity. In recognition of the importance of this active Earth system, officials of the U.S. Geological Survey (USGS), Yellowstone National Park, and the University of Utah in May of 2001 jointly established the Yellowstone Volcano Observatory (YVO). The stated objectives of this new observatory are: (1) to provide monitoring that enables reliable and timely warnings of possible renewed volcanism and related hazards in the Yellowstone region, (2) to notify National Park and other local officials and the public of any significant local seismic or volcanic events, (3) to improve scientific understanding of the fundamental tectonic and magmatic processes that create the Park's ongoing seismicity, surface deformation, and hydrothermal activity, (4) to assess the long-term potential hazards that volcanism, seismicity, and explosive or other convulsive hydrothermal activity might pose to the park and its surroundings, (5) to communicate as effectively as possible to responsible authorities and the public the results of scientific monitoring and hazard-assessment activities, and (6) to improve coordination and cooperation among the three institutions responsible for YVO. The observatory is built upon a substantial base of previous cooperative work among these institutions and seeks to assure a solid long-term basis for the continuity and improvement of scientific monitoring of the Yellowstone magmatic-tectonic-hydrothermal system.

The hazard assessment presented in this report is intended to help guide future activities of the observatory as well as to provide a basis for appropriate management actions by the National Park Service and other agencies in the Yellowstone area in the event of any future hazardous events that might result from activity of the Yellowstone system. The assessment is part of an ongoing three-part process that was set in motion at the outset of YVO's work. The first part of the process was a comprehensive review of basic scientific knowledge of Yellowstone's magmatic-tectonichydrothermal system. Such a review, of course, is never final and must be continually reexamined and revised, particularly in the light of current monitoring data. The second step of the process is assessment of the relevant hazards. The current hazards assessment is intended to be fully documented and scientifically defensible; because this necessarily entails a degree of scientific rigor and technical documentation not readily understandable by general readers or to all concerned individuals, additional reports more suitable for non-scientist readers also are part of the ongoing assessment activity. One general-interest publication on Yellowstone's volcano, seismic, and hydrothermal hazards has already been published (Lowenstern and others, 2005). The final step of the process will be a response plan, based upon the conclusions of this assessment, by the responsible Yellowstone National Park officials, in cooperation with other appropriate agencies and with the assistance of observatory scientists. 
It is worth noting here that, despite the fact that most of Yellowstone National Park and its nearby surroundings are sparsely populated, many thousands of people as well as National Park resources could be at risk from the types of hazards considered in this assessment. About 3 million people visit Yellowstone each year, principally during the three summer months. A similar number of people visit adjacent Grand Teton National Park (although some of these are the same visitors). Including residents of the surrounding communities of Wyoming, Idaho, and Montana, the daily population exposure to these hazards during the summer months could average between 70,000 and more than 100,000 persons. This exposure produces a largely unappreciated level of risk, comparable to that of other areas having considerably larger resident populations. Furthermore, the largest of these hazards, although they have the lowest probabilities of occurrence, could affect much of western and central North America. Indirect effects, especially on climate, could be global.

\section{Factors considered in this assessment}

In order to clarify the intended scope of this report, it is important to state at the outset just what factors are considered explicitly in this assessment. Hazards that might result from ongoing or future activity of the Yellowstone magmatic-tectonic-hydrothermal system, particularly volcanic eruptions, earthquakes, and hydrothermal eruptions, are the focus of this discussion. Certain other geologic hazards, although likely to be of important concern to National Park Service managers in the future, are not included within its scope. Examples of the latter would include landslides, debris flows, or floods, except insofar as they are considered here as possible consequential secondary hazards that might result from major volcanic, seismic, or hydrothermal activity.

The area considered in this hazard assessment is primarily Yellowstone National Park (fig. 1). Nevertheless, because most of the hazards considered here could have significant effects on adjacent communities, the Park boundary does not constitute an absolute limit in our analysis.

The strategy is to establish an integrated view of the sources of relevant hazards and some scenarios for how they might develop in time. This approach diverges from that of many previous USGS volcano-hazard assessments in not emphasizing a catalogue of individual hazardous processes and zonation maps for each of them. Rather, the emphasis is on (1) what kinds of monitoring data might be of immediate concern to National Park Service managers or might be considered premonitory to hazardous events, (2) the probabilities of recurring volcanic and acute hydrothermal events, and (3) how multiple events might be related to one another. Although the present open-file version of this report does not analyze earthquake hazards explicitly, a forthcoming revision for more formal publication will include seismic hazards.

\section{Current State of the Yellowstone system}

Assessment of possible future activity in Yellowstone starts from an analysis of the current state of the magmatic-tectonic-hydrothermal system. We first review the geologic framework and follow with information on current activity and monitoring of the system.

\section{Geologic background}

The Yellowstone Plateau volcanic field of Wyoming, Idaho, and Montana (fig. 2) is one of Earth's largest young volcanic systems, having erupted extraordinarily voluminous rhyolites episodically over a little more than 2 million years (Christiansen, 1984; 2001). Its three largest eruptions deposited sheets of mainly welded ash-flow tuffs regionally as well as coeval ash-fall layers that fell over much of western and central North America (fig. 3). The volcanic field is the current expression of a major sublithospheric mantle source that generates a melting anomaly that 
has propagated northeastward at least $300 \mathrm{~km}$ relative to the North America craton since its initial volcanism at 17-14 Ma (fig. 4). Researchers debate the nature of this melting source-whether, for example, it represents a convective thermal plume from the base of the mantle or from the mantle transition zone, an entirely upper-mantle response to plate-tectonic processes, or some other mechanism (e.g., Pierce and Morgan, 1992; Smith and Braile, 1993, 1994; Pierce and others, 2000; Christiansen and others, 2002; Camp and Ross, 2004; Waite and others, 2006). These varied hypotheses are significant to interpretation of regional geophysical data but have only an indirect bearing on the present analysis of volcanic hazards.

The volcanic field has evolved episodically in three cycles of rhyolitic activity. Each cycle culminated in the rapid eruption of voluminous rhyolitic ash flows-hundreds to thousands of cubic kilometers - and consequent catastrophic subsidence of the source areas to form large calderas. Each climactic ash-flow eruption was preceded by a period of magmatic intrusion and intermittent rhyolitic lava eruptions and was followed by a period of partial filling of the calderas with rhyolitic lavas. During each of these cycles, basaltic lavas erupted around the margins of the active rhyolitic source area but not within it. About a million years after their rhyolitic activity, basalts finally erupted through the source areas of the first two cycles, but no basalts have yet erupted within the youngest, the Yellowstone caldera.

Collectively, the voluminous rhyolitic ash-flow tuffs of the volcanic field are known stratigraphically as the Yellowstone Group (Christiansen and Blank, 1972). The oldest and largest of the caldera-forming eruptions produced the Huckleberry Ridge Tuff at 2.059 $\pm 0.004 \mathrm{Ma}$ (Lanphere and others, 2002), covering an area of more than $15,000 \mathrm{~km}^{2}$ with ash flows having a cumulative volume of at least $2,450 \mathrm{~km}^{3}$. The resulting caldera (fig. 5, purple line) spanned nearly the entire width of the Yellowstone Plateau volcanic field (Christiansen, 1979, 2001). The Mesa

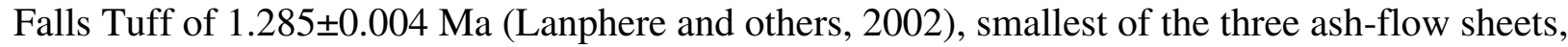
erupted in the Island Park area west of the Yellowstone Plateau (Christiansen, 1982, 2001) and is now exposed mainly in that vicinity, adjacent to its source caldera (fig. 5, blue line). The Mesa Falls probably initially covered an area of more than $2,700 \mathrm{~km}^{2}$ and had an eruptive volume of more than $280 \mathrm{~km}^{3}$. The youngest of the major caldera-forming eruptions at $0.639 \pm 0.002 \mathrm{Ma}$ (Lanphere and others, 2002) produced the Lava Creek Tuff and the Yellowstone caldera, now the central feature of the volcanic field (Christiansen, 1984). Two distinct parts of the Lava Creek Tuff erupted from separate segments of the caldera (Christiansen, 1979, 2001) but form a single compound cooling unit that initially covered at least $7,300 \mathrm{~km}^{2}$ and had an eruptive volume of at least $1,000 \mathrm{~km}^{3}$.

Precaldera rhyolitic lavas of the third volcanic cycle erupted from a growing ring-fracture system in the area that subsequently became the Yellowstone caldera. Eight such precaldera rhyolite flows are known, yielding isotopic ages from 1.22 \pm 0.01 to $0.609 \pm 0.006 \mathrm{Ma}$ (table 1; see note on the table regarding the accuracy of cited ages). Additional precaldera rhyolitic lava flows may now lie entirely buried within the Yellowstone caldera. The precaldera lavas, named the Mount Jackson Rhyolite and Lewis Canyon Rhyolite, and the growing ring-fracture system from which they extruded (fig. 6) are interpreted as indicating magmatic intrusion and the growth of a large rhyolitic magma chamber in the shallow crust during a period of nearly 600,000 years beneath the area that would later erupt catastrophically to produce the Lava Creek Tuff and subside to form the Yellowstone caldera (fig. 7).

Shortly following the climactic caldera-forming Lava Creek eruption, rhyolitic magma again intruded the subcaldera region, uplifting segments of the caldera floor in a pair of resurgent domes bounded by two inner ring-fracture segments enclosed by an outer ring-fracture zone encompassing nearly the entire Yellowstone caldera (Christiansen, 2001). The western of these resurgent domes is the Mallard Lake dome (fig. 7, ML); the eastern is the Sour Creek dome (fig. 7, SC). Subsequently, additional rhyolitic lavas have erupted within the caldera during several 
volcanic episodes. These rhyolites, mainly constituting large lava flows, are included stratigraphically in the Plateau Rhyolite. The oldest of the Plateau Rhyolite flows, the Upper Basin Member, erupted within the caldera from around the inner ring-fracture zones that bound the two resurgent domes (fig. 7). These oldest postcaldera rhyolites yield isotopic ages that range between $516 \pm 7$ and $479 \pm 10 \mathrm{ka}$ (Gansecki and others, 1996) though there is a reasonable possibility that their actual eruptive ages were even closer to that of the $~ 639$-ka Lava Creek Tuff (see Lanphere and others, 2002). Buried rhyolitic lavas identified in recent high-resolution sonar and seismicreflection mapping of Yellowstone Lake (Morgan and others, 2003b) and found as lithic clasts in postglacial hydrothermal-explosion deposits south of the Sour Creek dome and in northern Yellowstone Lake yield a ${ }^{40} \mathrm{Ar} /{ }^{39} \mathrm{Ar}$ age of $600 \pm 20 \mathrm{ka}$ (Morgan and Shanks, 2005). Additional postcaldera lava, probably as young as $275 \pm 11 \mathrm{ka}$ is known (table 1 ). Other lavas may well have extruded within the caldera during the time before about $170 \mathrm{ka}$ but remain buried beneath younger lavas and sediments.

Younger postcaldera rhyolitic volcanism dates from about $170 \mathrm{ka}$ (Christiansen, 2001). This activity probably began with extrusion of rhyolitic lava onto the Mallard Lake resurgent dome in the western part of the Yellowstone caldera (the Mallard Lake flow) followed by renewed uplift of that dome. Following those events, as much as several hundred cubic kilometers of rhyolitic lava (figs. 8 and 9), named the Central Plateau Member of the Plateau Rhyolite, has nearly filled the Yellowstone caldera from eruptive vents along two linear northwest-trending zones that project across the caldera from neighboring tectonic fault zones. The western of these two zones extends from the Teton fault zone (see fig. 11) to the tectonic basin of West Yellowstone. Lavas from these vents form the Pitchstone and Madison Plateaus (fig. 1) and bury the western rim of the Yellowstone caldera. The eastern zone extends northward across the caldera from the Sheridan fault zone (see fig. 11) to the Norris Geyser Basin and erupted the lavas that form the Central Plateau. The lava flows from this youngest intracaldera activity are typically quite large - some of them exceeding $20 \mathrm{~km}^{3}$ - and appear to have erupted in five episodes at about $164 \pm 5,152 \pm 3$, $114 \pm 2,102 \pm 5$, and $72 \pm 4 \mathrm{ka}$ (table 2 and figs. 8 and 9). It is likely that rhyolitic pumice and ash erupted during the opening of vents for each of these lava flows. In addition, concurrent with lava eruptions of the Central Plateau Member, at least two significant pyroclastic eruptions occurred within the caldera, depositing the tuffs of Bluff Point and Cold Mountain Creek. The former was of sufficiently large volume to have caused subsidence of its source area to form a smaller caldera ( 10-km diameter) within the Yellowstone caldera, now partly preserved as West Thumb (fig. 8), the western part of Yellowstone Lake (Christiansen, 2001). It is worth noting that this relatively small caldera is itself as large as the well-known caldera of Crater Lake, Ore., which formed as a result of the pyroclastic eruption of more than $50 \mathrm{~km}^{3}$ of magma (Bacon, 1983).

Volcanism postdating the Yellowstone caldera also has occurred in areas outside the caldera but within or near the boundaries of Yellowstone National Park. The individual eruptive products of this extracaldera volcanism are generally smaller in volume than most of those within the caldera but span nearly the same range of time as the intracaldera lavas. Both rhyolites and basalts occur among these extracaldera lavas. $\mathrm{K} / \mathrm{Ar}$ and ${ }^{40} \mathrm{Ar} /{ }^{39} \mathrm{Ar}$ ages obtained on the rhyolites range between $526 \pm 3$ and $80 \pm 2 \mathrm{ka}$ (table 1). Basaltic eruptions appear to have spanned much of the same time. Basalts and rhyolites both erupted mainly in the southern part of the Norris-Mammoth corridor, a zone of faulting, volcanism, and hydrothermal activity that extends northward from the caldera margin near Norris Geyser Basin to just north of Gardiner, Mont. (figs. 10, 11). Other rhyolites and basalts of similar ages have erupted northwest of the caldera, between the Madison River and Cougar Creek, and near the southern boundary of Yellowstone National Park. Furthermore, basalts erupted from at least 17 vents in the basin of Island Park, within $35 \mathrm{~km}$ of the west boundary of Yellowstone National Park (fig. 10). 
Hydrothermal activity occurs widely on and around the Yellowstone Plateau. Most of the hottest and most active areas of geysers and other near-neutral (i.e., non-acidic) hot springs occur within topographic basins situated above the ring-fracture zone of the Yellowstone caldera-including Yellowstone Lake (Johnson and others, 2003; Morgan and others, 2003a; Morgan and others, 2003b) - but others occur in the Norris-Mammoth corridor north of the caldera. Other major sites of mainly acidic, sulfate-rich hot-springs and fumaroles occur in topographically higher areas in and adjacent to the ring-fracture zone and the northeastern caldera rim. Smaller, less concentrated zones of hydrothermal activity are distributed widely around the Yellowstone National Park, but most areas deemed capable of producing violent events such as hydrothermal explosions are in the major hydrothermal areas within or adjacent to the caldera and in the NorrisMammoth corridor.

Regional uplift and normal faulting have established the geologic framework within which the Yellowstone Plateau volcanic field lies (figs. 4 and 11). Faults mapped within the caldera are mainly small and seem to reflect strains associated with magmatic intrusion and, perhaps, shallow hydrothermal activity. The principal faults south of the caldera that accommodate regional tectonic extension generally trend nearly north-south and define the Teton, Sheridan, Flat Mountain, and Upper Yellowstone fault zones. Major fault zones north of the caldera include the Lamar, East Gallatin-Washburn, Hebgen, and Madison Valley fault zones, many of them trending more nearly northwest. A little farther west, the Centennial fault zone trends east-west. The somewhat arcuate Mirror Plateau fault zone northeast of the caldera (figs. 6 and 11) appears to have accommodated both regional tectonic extension and displacements associated directly with the Yellowstone caldera system (Christiansen, 2001).

Bathymetric and seismic-reflection studies have delineated several small faults beneath Yellowstone Lake (Otis and others, 1977; Wold and others, 1977; Johnson and others, 2003; Morgan and others, 2003b). At least the major sublacustrine faults appear to represent continuations of the regional tectonic trends noted above (Morgan and others, in press-b).

Thermal surveys of Yellowstone Lake (Morgan and others, 1977), together with geochemical indicators of the heat output of the Yellowstone hydrothermal system (Fournier, 1989), demonstrate that the total heat flux from the Yellowstone caldera exceeds $1500 \mathrm{~mW} / \mathrm{m}^{2}$, more than thirty times the regional average. This great thermal flux is a direct reflection of the magmatic heat source that produces and sustains Yellowstone's hydrothermal activity.

\section{Contemporary activity}

The tectonic-volcanic-hydrothermal system of the Yellowstone region is vigorously active. The hydrothermal system may be the largest on Earth, and the subsurface magmatic system continually deforms the ground surface on time scales of months to a few years. Regional tectonics and the magmatic system combine to produce some of the highest levels of earthquake activity in the conterminous U.S. outside of California.

\section{Seismicity}

Although physiographically part of the Middle Rocky Mountains, Yellowstone lies along the northeastern margin of the extensional basin-range tectonic region (figs. 4 and 11). Epicenters of earthquakes associated with this tectonic extension define a belt of seismicity that extends north from the Wasatch front in Utah to the Yellowstone Plateau, then branches to the northwest and west into Montana and Idaho, termed the intermountain seismic belt by Smith and Sbar (1974). Earthquake epicenters define a parabolic arc around the north, east, and south sides of the eastern Snake River Plain through the Yellowstone Plateau, where the seismicity is most active (Smith and Arabasz, 1991; Smith and Braile, 1994) and fault displacements are greatest (Anders and others, 
1989; Pierce and Morgan, 1992). Earthquake distributions, focal mechanisms, and GPS determinations of crustal strain in the Yellowstone Plateau area are all consistent with the generally NE-SW direction of extension in the basin-range region (Waite and Smith, 2004; Puskas and others, 2007).

Seismicity in the Yellowstone National Park region is monitored in real time by a network of 26 seismic stations within or adjacent to the park (fig. 12), all of which are recorded at the University of Utah as an integral part of the YVO program and archived in the Advanced Seismic Network System. Of these seismic stations, 17 are single-component short-period seismometers connected to the network by analog telemetry. Additionally, there are three short-period 3component seismometers with analog telemetry and six broadband 3-component seismometers with digital telemetry (Yellowstone Volcano Observatory, 2006). Data are transmitted continuously from the seismic stations via radio signals to a Federal Aviation Administration (FAA) radar site located on Sawtell Peak, Idaho, west of Yellowstone National Park, where the signals are multiplexed onto four FAA microwave lines for retransmission to the FAA control center in Salt Lake City, Utah. From there, the data are transmitted to the University of Utah's central recording laboratory via telephone lines. Earthquake data are processed using the USGS EarthWorm system to produce automated real-time hypocenter determinations and emergency-response broadcasts. Refined earthquake locations, magnitudes, and focal mechanisms are produced by seismic analysts at the University of Utah Seismograph Stations from the digital data and are provided to YVO users.

Given its average station spacing of $15-30 \mathrm{~km}$ and seismometer characteristics, the Yellowstone network is optimally capable of detecting local earthquakes of magnitudes greater than about -1.0 and locating their epicenters within about $1 \mathrm{~km}$ and their focal depths within about $0.5 \mathrm{~km}$ at depths below about $4 \mathrm{~km}$ (or about $1 \mathrm{~km}$ at shallower depths). Analysis of the digital seismic data includes production of a revised catalog of Yellowstone earthquakes using new threedimensional P-wave velocity models determined by tomographic inversion of local earthquakes (Husen and Smith, 2004) and a new magnitude scale for improved hazard assessments.

It is useful to consider seismicity of the Yellowstone region in terms of several categories of activity. Most Yellowstone earthquakes (fig. 13) are of small magnitude (Ms3), but a few large tectonic earthquakes have affected the region, including the deadly Hebgen Lake earthquake of August 17, 1959, with a magnitude of 7.5 (U.S. Geological Survey, 1964; Trimble and Smith, 1975; Doser, 1985; Doser and Smith, 1989). Aftershocks of the Hebgen Lake earthquake were numerous (Murphy and Brazee, 1964), and a high proportion of the earthquakes since then have occurred in the same belt of seismicity as those early aftershocks (Trimble and Smith, 1975; Smith and others, 1977; Smith and Braile, 1994). Numerous other earthquakes, including many within the Yellowstone caldera, are scattered more widely, are typically shallow, and commonly occur in the form of seismic swarms. Seismicity beneath the Yellowstone caldera is generally shallower $(\sim 5$ $\mathrm{km})$ relative to the deepest earthquakes $(\sim 20 \mathrm{~km})$ on tectonic faults outside the caldera, probably related to the effects of elevated crustal temperature above the magma that underlies the caldera (Miller and Smith, 1999; Waite and Smith, 2002; Husen and Smith, 2004). Thus, seismicity can be discussed in four categories: large earthquakes on regional tectonic faults, smaller tectonic earthquakes, intracaldera earthquakes, and seismic swarms.

The 1959 Hebgen Lake earthquake had the largest magnitude of any historic earthquake in the Rocky Mountains region (fig. 13). That earthquake produced a pair of fault scarps up to $6 \mathrm{~m}$ high and $40 \mathrm{~km}$ long, caused a landslide that dammed the Madison River northwest of Hebgen Lake about $30 \mathrm{~km}$ west of Yellowstone National Park, caused extensive damage to roads and buildings within the park, and resulted in 28 deaths - all of them in the National Forest, outside the park. The only other regional historic earthquake of roughly comparable magnitude was the M=7.3 Borah Peak, Idaho, earthquake of 1983, about 150 km southwest of Yellowstone National Park 
(Dewey, 1983; Smith and others, 1985; Crone, 1987; Richins and others, 1987). It too produced a long surface scarp and resulted in local damage. Both of these earthquakes caused discernable changes in the hydrothermal features of Yellowstone (Watson, 1961; Marler, 1964; Marler and White, 1975; Hutchinson, 1985). Prehistoric late Holocene scarps occur on several range fronts near Yellowstone, including the Centennial, Madison, and Teton Ranges (pl. 1 of Pierce and Morgan, 1992), indicating the possibility of further large tectonic earthquakes in the region.

Smaller tectonic earthquakes on regional faults occur widely in areas in and adjacent to Yellowstone National Park (Smith and Sbar, 1974; Doser and Smith, 1983; Waite and Smith, 2002, 2004; White, 2006). Recurring seismicity of this type is common and must be expected in the future. Most of these earthquakes are small and cause no significant damage. Others are felt locally, and some have the potential to cause damage to structures or other facilities.

Intracaldera earthquakes are typically small $(M \leq 3)$ and generally are shallower than about 6 km (Miller and Smith, 1999; Husen and Smith, 2004; Waite and Smith, 2004). A few however, are larger and can be damaging. The largest earthquake recorded within the caldera area occurred southeast of Norris Geyser Basin (fig. 13) in June, 1975 with a magnitude of 6.1 (Pitt and others, 1979). The earthquake, felt widely within Yellowstone National Park, caused damage to roads and other visitor facilities. The area in which it was felt was more extensive to the north, outside the caldera, than within the caldera, probably because of the attenuating effects of elevated crustal temperatures beneath the caldera. Aftershocks occurred within a zone $10 \mathrm{~km}$ long that included the main shock as well as on a parallel zone of seismicity about $5 \mathrm{~km}$ to the west that had been intermittently active for the preceding year.

As is common in other volcanic and geothermal areas, many of the earthquakes in or adjacent to the Yellowstone caldera occur in swarms (Smith and Braile, 1994; Waite and Smith, 2002; Farrell, 2007),. These swarms are characterized by numerous small, generally shallow earthquakes clustered in both space and time, without a mainshock, and having magnitude differences $\leq 0.25$. Commonly these swarms are aligned on tectonic trends, though not necessarily on recognized faults, and are generally considered to be related to migration of hydrothermal fluids or magma in the shallow crust. A particularly intense earthquake swarm (fig. 14) occurred in October and November of 1985 a short distance northwest of the Yellowstone caldera (Waite and Smith, 2002). With time, the swarm activity migrated both away from the caldera and, to a lesser extent, downward as the caldera itself underwent a change from uplift to subsidence. The swarm was likely to have been related to the subsurface movement of hydrothermal fluids or magma from beneath the caldera, deflating the caldera area and possibly penetrating the shallow crust nearby as magmatic dikes that did not breach the surface in eruption (Waite and Smith, 2002). Possible migration of magma may have induced local migration of hydrothermal fluids and magmatic gases (Husen and others, 2004).

Induced or triggered earthquakes constitute another class of seismicity observed recently in Yellowstone (Husen and others, 2004). Such earthquakes are triggered by the passage of largeamplitude surface waves from distant sources to produce local transient dynamic stress changes as great as $0.15 \mathrm{MPa}$. A series of local earthquake swarms was observed, and clear changes in geyser activity occurred immediately following local arrival of seismic waves from the 2002 Denali fault, Alaska, earthquake (M=7.9) in the Yellowstone National Park area, $3100 \mathrm{~km}$ from the epicenter. Beginning within hours of the arrival of surface waves, the YVO network located more than 250 earthquakes in the first days after the Denali event. The eruption frequency of several geysers was altered, and numerous earthquake swarms close to major geyser basins were unusual in occurring simultaneously in different geyser basins. This behavior is interpreted as having been induced by dynamic stresses associated with the passage of large-amplitude surface waves, perhaps locally altering the permeability of hydrothermal plumbing by unclogging existing fractures. Furthermore, redistribution of hydrothermal fluids and locally increased pore pressures triggered earthquakes in 
these swarms. Although earthquake triggering and changes in geyser activity have been documented elsewhere, these notable changes at Yellowstone induced by a large-magnitude event at such a great distance indicate the profound effects that remotely triggered seismicity can have on hydrothermal and earthquake hazards and also suggests that earthquakes and hydrothermal explosions at Yellowstone might be triggered by local earthquakes in the future.

\section{Crustal deformation}

Major surface deformation has been recognized in Yellowstone since precise leveling surveys were repeated in 1975-1977 after a lapse of 50 years. Caldera-wide uplift to a maximum of at least $73 \mathrm{~cm}$ (fig. 15) was documented in these surveys (Pelton and Smith, 1979, 1982). Similar uplift continued, as measured repeatedly in several following years (fig. 16), averaging $23 \mathrm{~mm} / \mathrm{y}$ from 1976 to 1983, then slowing down for about a year before subsiding as much as $35 \mathrm{~mm} / \mathrm{y}$ until 1987 (Dzurisin and Yamashita, 1987; Dzurisin and others, 1990).

Since these surveys, newer methods, including the Global Positioning System (GPS) and Interferometric Synthetic Aperture Radar (InSAR) have shown that surface deformation remains active over the entire area of the Yellowstone caldera and the seismically active area to the northwest, including the epicenter of the 1959 Hebgen Lake earthquake. Both uplift and subsidence occur in this area, sometimes in a caldera-wide fashion and at other times in more complex patterns of more local uplift and subsidence (Meertens and Smith, 1991; Wicks and others, 1998; Puskas and others, 2002; Wicks and others, 2006; Puskas and others, 2007).

Currently, deformation monitoring of the Yellowstone region is carried out by YVO mainly through a network of 16 GPS receivers (Yellowstone Volcano Observatory, 2006), of which 12 are located within Yellowstone National Park (fig. 17), continuously recorded at the University of Utah and by the EarthScope Plate Boundary Observatory. Additional stations are planned for future installation. Each station records a time series of 2 horizontal components and 1 vertical component sampled every 5 seconds, which are analyzed at the University of Utah to produce coordinate solutions. In addition, about 60 GPS stations are recorded in special surveys rather than being monitored continuously. Repeat leveling surveys also continue intermittently.

Together, the geodetic data reveal complex patterns of crustal deformation over a period of decades (fig. 14), as summarized by Puskas and others (2007). From 1923 to 1985 caldera-wide uplift occurred at an average rate of $22 \mathrm{~mm} / \mathrm{yr}$, changing in 1986 to subsidence. Subsidence continued within the Yellowstone caldera to 1995 at $14 \mathrm{~mm} / \mathrm{yr}$ while uplift occurred northwest of the caldera at $5 \mathrm{~mm} / \mathrm{yr}$. In 1995, caldera uplift resumed at $9 \mathrm{~mm} / \mathrm{yr}$, changing again in 2000 to subsidence at $9 \mathrm{~mm} / \mathrm{yr}$ while uplift continued northwest of the caldera at an average of $12 \mathrm{~mm} / \mathrm{yr}$. A sudden change in 2004 to caldera uplift proceeded at unprecedented rates of up to $60 \mathrm{~mm} / \mathrm{yr}$, continuing into 2007. These rapid changes in motion across the Yellowstone caldera over more than a half century clearly reflect the importance of transient large-scale crustal deformation sources that probably include both the subcaldera magma chamber and localized zones of pressurized hydrothermal fluids that inflate and deflate the surface as the locations and properties of the sources change with time.

Detailed analysis of ancient shorelines of Yellowstone Lake, both subaerial and sublacustrine, indicates that similar changes of major uplift and subsidence date back at least as far as the final retreat of Pleistocene glaciers from the lake basin (Meyer and Locke, 1986; Locke and Meyer, 1994; Pierce and others, 2002; Johnson and others, 2003). Pierce and colleagues (2002) conclude that cycles of uplift and subsidence have occurred repeatedly in the Yellowstone Lake basin during the past 14,000 years; the record of these cycles is superposed on the record of a longterm decrease in lake level by downcutting of the lake outlet, but that little net elevation change occurred between about $14 \mathrm{ka}$ and $3 \mathrm{ka}$ (fig. 18). 
Together, earthquake focal mechanisms and both vertical and horizontal deformation patterns suggest that the crustal stress field recorded both by earthquakes and by surface deformation are generally consistent with regional basin-range extension. In the vicinity of the Yellowstone caldera, however, the stress field is strongly modified by the effects of migrating magmatic and hydrothermal fluids to produce changes in seismicity, uplift, and subsidence on time scales of months to a few years (Dzurisin and others, 1990; Dzurisin and others, 1994; Puskas and others, 2002; Waite and Smith, 2002; Husen and others, 2004; Waite and Smith, 2004; Wicks and others, 2006; Puskas and others, 2007).

\section{Hydrothermal and gas activity}

At each eruption, immediately preceding, was an upheaval of some fifty feet high, followed by one great explosion in which the water was thrown two hundred fifty to three hundred feet and frequently hurling stone one foot in diameter five hundred feet from the crater.

Joaquin Miller (in Muir, 1888), describing hydrothermal explosions of Excelsior Geyser.

Yellowstone National Park hosts one of the largest hydrothermal systems on Earth and, in particular, has more geysers than all others in the world together. Most of these hot springs, geysers, and fumaroles present hazards only to visitors who may stray from established pathways into areas of unstable ground and hot water; it is impractical to consider such daily hazards in the context of the present assessment. One of the most common acute geological hazards at Yellowstone, however, consists of shallow-rooted explosions of steam, water, and rock without any associated volcanism. These hydrothermal explosions (or eruptions) occur when hot subsurface waters flash to steam, violently breaking the confining rocks and ejecting them from a newly formed or existing crater. Individual events can last as briefly as a few seconds or as long as several hours, and intermittent explosive activity can continue for years.

Hydrothermal-explosion craters are found in Yellowstone National Park at scales ranging from less than a meter to several kilometers in diameter (Muffler and others, 1971; Morgan and others, in review). Visitors to popular thermal areas like Upper and Lower Geyser Basins, Norris Geyser Basin, and West Thumb Geyser Basin see circular, funnel-shaped pools, often with jagged walls, filled with thermal water (fig. 19). Many of these pools appear to have formed in hydrothermal explosions (Marler and White, 1975). Porkchop Geyser in Norris Geyser Basin, Excelsior Geyser in Midway Geyser Basin, and Seismic Geyser in Upper Geyser Basin have produced well-documented historical explosions (Marler and White, 1975; Fournier, 1989; Whittlesey, 1990). Geologic research has identified many large craters formed before the time of historical records, including a number at and near the north edge of Yellowstone Lake (fig. 20: Mary Bay, Indian Pond, and Turbid Lake; also see fig. 24). If similar large explosions were to occur today in that vicinity, they could threaten infrastructure and visitor safety along the East Entrance Road, at Fishing Bridge and as far away as Lake Village. Geologic and historic evidence in Yellowstone and elsewhere suggests that such hazardous activity could last days, weeks or even years.

Browne and Lawless (2001) provide a lengthy summary of current knowledge of hydrothermal "eruptions" around the world, preferring the word eruption over explosion to reinforce the idea that the events were part of a continuum extending from geysering (no rocks ejected) to very large rock-hurling eruptions creating craters hundreds to thousands of meters across. While acknowledging the terminology of Browne and Lawless (2001) but to avoid confusion with magmatic eruptions, we continue to use the term hydrothermal "explosions" in this hazards assessment for events that can form craters or eject rocks.

We follow Browne and Lawless (2001) in distinguishing hydrothermal eruptions/explosions from other types of ground water eruptions such as: 
Phreatic eruption: An eruption of steam, water and rock caused when cool ground water is heated rapidly to its boiling point by magmatic heat but no magma is actually erupted.

Phreatomagmatic eruption: Similar to a phreatic eruption but with evidence for eruption of magma as well as fragments of the confining rock.

Magmatic-hydrothermal eruption: An eruption caused by magma heating a pre-existing hydrothermal system; the magma may or may not reach the surface as a part of the ejected materials. An excellent example occurred in New Zealand in 1886, when intrusion of basaltic magma into a long fracture system caused hydrothermal explosions as far as $20 \mathrm{~km}$ away from the lava vent (Hedenquist and Henley, 1985; Simmons and others, 1993).

In contrast, hydrothermal eruptions/explosions occur in pre-existing hydrothermal systems without the proximate influence of magma. It appears that all explosions at Yellowstone since the latest glaciation, roughly the past 16,000 years, are true hydrothermal explosions with no direct participation of magma.

Pressures, temperatures, and fluids in geothermal systems

Understanding the causes of hydrothermal explosions requires understanding the structure and dynamics of geothermal systems. Such systems are regions of anomalous heat flow in the shallow crust of the Earth. Geothermal systems can be divided into two distinct types: hot-water (or liquid-dominated) systems and vapor-dominated systems (White and others, 1971).

In a liquid-dominated system, the Earth's subsurface is saturated with hot water, which is located in interconnected pore spaces and fractures. Liquid-dominated systems can have two types of surface manifestations: a) hot springs, which can represent the direct outflow of hot water from the geothermal reservoir, and b) fumaroles, which represent steam and gas boiled off the reservoir. At Yellowstone National Park, the hot springs of liquid-dominated systems are typically neutral or slightly alkaline, $\mathrm{Cl}$-rich, and are saturated with silica $\left(\mathrm{SiO}_{2}\right)$. As these waters cool, they precipitate amorphous silica as deposits called siliceous sinter. Waters that precipitate silica are common in, but are not limited to, the Upper and Lower Geyser Basins, the Norris Geyser Basin, the West Thumb Geyser Basin (Fournier, 1989) and sublacustrine hydrothermal vents in Yellowstone Lake (Shanks and others, 2005; Shanks and others, in review).

Vapor-dominated systems lack sufficient water for complete liquid saturation of the reservoir, resulting in low-density steam and gas being the interconnected phase. Vapor-dominated reservoirs can still contain an appreciable amount of liquid, which remains within pore spaces in the host rock. Surface manifestations above vapor-dominated reservoirs typically consist of "acidsulfate" features such as fumaroles, acid pools, and mud pots. Hot springs issuing neutral waters are usually absent. Instead, acid pools and mud pots form due to condensation and oxidation of acid gases and steam in perched bodies of surface and near-surface water. Most of the large thermal areas in the eastern part of Yellowstone National Park (e.g., Mud Volcano, Hot Springs Basin, Sulphur Hills, Josephs Coat) formed above vapor-dominated geothermal areas and have acid-sulfate soils and widespread alteration of surface rocks, commonly to clays (White and others, 1971; White and others, 1975).

The simplest geothermal reservoir at Yellowstone consists of ground water at its boiling temperature for a given hydrostatic head (fig. 21). In these situations, pressure is dictated by the weight of the interconnected column of subsurface and surface water. Under normal conditions, the confining pressure is sufficient to prevent the water from boiling catastrophically. Geyser eruptions occur when subtle boiling at the top of the column induces local depressurization and consequent boiling further down the column. Conditions such as a landslide, earthquake, or dambreak may cause a large and sudden decrease in pressure; geothermal water then may become highly superheated relative to its boiling temperature at the new, lower pressure, causing rapid conversion of some of the water to steam, forcing expansion, and triggering an explosion. 
Hydrothermal explosions can be initiated more readily when pressures exceed hydrostatic. Ideally, because the density of hot water is less than that of cold water, hydrothermal systems should be slightly under-pressured with respect to the cooler surrounding ground water systems. However, mineral-precipitation reactions, especially those forming silica, serve to clog permeable pathways in the aquifer and can cause the geothermal waters to become isolated with respect to their surroundings. Moreover, the presence of gas and steam can increase the pressure of the system. As a result, many geothermal drill holes, including research holes drilled at Yellowstone in the 1960s (White and others, 1975), are positively pressured with respect to the predicted hydrostatic gradient (fig. 22).

An additional factor increasing the pressure within geothermal areas is the buildup of gases such as carbon dioxide $\left(\mathrm{CO}_{2}\right)$ and hydrogen sulfide $\left(\mathrm{H}_{2} \mathrm{~S}\right)$, which do not condense upon ascent and cooling and can build up in concentration beneath an impermeable caprock (Hedenquist and Henley, 1985). At the vapor-dominated Ngawha system in New Zealand, for example, extrapolations of deep gas pressures to near surface conditions could allow a hydrothermal eruption that would lift and disperse about $130 \mathrm{~m}$ of overlying rock (Browne and Lawless, 2001). Thus, vapor-dominated reservoirs also can experience hydrothermal explosions, either owing to buildup of non-condensable gases or simply by release of superheated steam. In general, explosions from vapor-dominated reservoirs are thought to be somewhat less dangerous than liquid-dominated reservoirs because a given volume of steam will contain less potential energy than the same volume of liquid at the same temperature. Even in vapor-dominated reservoirs, most of the potential energy of the system resides within the residual liquid water (Browne and Lawless, 2001).

\section{Mechanisms of hydrothermal explosion}

The mechanisms for hydrothermal explosions recognized by Browne and Lawless (2001) are summarized here in the context of the geothermal system at Yellowstone.

Pressures exceeding lithostatic: A hydrothermal explosion can occur if fluid pressure is regulated by an impermeable caprock, such that pressures increase until they exceed the weight and strength of the overlying rock. This mechanism is thought to be comparatively rare at geothermal fields, where measured pressures are usually well below lithostatic, but eruptions from these fields are relatively common. Moreover, the common hot springs and fumaroles at the surface above geothermal fields imply that their caprock is not generally impermeable. At Yellowstone, it is clear that areas affected by hydrothermal explosions are those having already-established reservoirs connected to distinct surface expressions. Browne and Lawless (2001) infer that this mechanism is most important above young geothermal reservoirs as they start to interact with overlying, as yet unaltered, surface rocks. Phreatic eruptions at reactivating volcanoes also might occur when transients in ground water pressures exceed the lithostatic load. Potentially, self-sealing due to precipitation of minerals from hydrothermal fluids could decrease the permeability of hydrothermal aquifers, causing pressures to approach lithostatic.

Slow accumulation of steam and/or gas: Pressures can more regularly exceed lithostatic if steam is present in the system and can ascend, transmitting pressure to shallower regions. This is thought to be the common mechanism for explosions in exploited geothermal fields (Browne and Lawless, 2001) when withdrawal of geothermal fluid lowers subsurface pressures, thereby triggering additional boiling. Because cooling of noncondensable gas has a negligible effect on its volume, its presence will increase the likelihood of overpressure. Long-term drought and a drop in ground water levels could cause a similar phenomenon wherein shallow steam pressures increase with a decrease in the elevation of the ground water table (fig. 23, adapted from fig. 6 of Browne and Lawless, 2001).

Rapid subsurface pressure release: Any geothermal system that follows the boiling point with depth can be triggered into an eruption by a sudden release in pressure that causes flashing of 
liquid water to steam. Such a pressure release could result from an earthquake, a landslide, draining of a lake, deglaciation, or a hydrothermal fracturing event within the reservoir. At Yellowstone, such events are known to have caused hydrothermal perturbations. The 1959 Hebgen Lake earthquake ( $M=7.5)$ induced eruptions of some 289 springs, including 150 with no previous record of geysering (Marler, 1973). Most of these eruptions were solely of liquid water and steam, though Marler and White (1975) document the growth of a new feature, Seismic Geyser, whose genesis involved a series of rock-hurling episodes. Muffler and others (1971) postulated that the very late Pleistocene Pocket Basin explosion in the Lower Geyser Basin was initiated by drainage of a postglacial lake, causing a pressure drop in the underlying geothermal reservoir.

Addition of magmatic heat or gas: Addition of external magmatic heat or gas yields what is termed a magma-hydrothermal eruption. One might consider all heat at Yellowstone to be ultimately magma-derived, but the term is used here to denote a rapid transfer of heat from a shallow magmatic intrusion directly into the geothermal system. Though such a mechanism is unlikely for the small shallow explosions most common at Yellowstone, its importance cannot be ruled out for some of the earlier large hydrothermal explosions of the late Pleistocene and early Holocene. If magma, however, did induce some of the large explosions, it did so without reaching the surface.

Progressive flashing: Browne and Lawless (2001) conclude that this is the most common type of hydrothermal explosion. It initiates close to the ground surface and works its way downward with time as rocks fracture, causing the boiling front to move down, resulting in increased boiling, brecciation, and depressurization of the underlying system. The model requires that boiling water exists near the surface and overlies water at a boiling-point-for-depth temperature gradient. As such, the initial confining pressure can be minimal, and open pools can be the site of initiation. The eruption itself might be triggered by events like those described in the subsurface pressure release model, but with the boiling water column destabilizing much closer to the surface.

\section{Hydrothermal explosions in Yellowstone}

At Yellowstone, a geologic record of hydrothermal explosions exists only for events occurring after the most recent glaciation (ending about 16,000 years ago, Pierce and others, 2002), which effectively erased evidence of any earlier such events. Evidence for eighteen large (>100-m) hydrothermal explosions (table 3; fig. 24) is found within Yellowstone National Park (Morgan and others, in review). Many large explosion craters are present on land, but others have been identified in Yellowstone Lake (Wold and others, 1977; Morgan and others, 2003b; Morgan and others, in press-b; Morgan and others, in review). Most of the largest explosion craters, such as Mary Bay, Turbid Lake, Duck Lake, Indian Pond, and Pocket Basin (fig. 24), are found within and along the margin of the 640-ka Yellowstone caldera. A few are present along the tectonically controlled, north-trending Norris-Mammoth corridor. The hydrothermal-explosion craters appear to be relatively shallow features affecting only the upper several hundred meters of substrata, which typically have been previously affected by hydrothermal alteration (Muffler and others, 1971; Morgan and others, in review). In Yellowstone, no large hydrothermal explosion is associated with a volcanic event, and no evidence exists for a hydrothermal explosion triggering any volcanism.

Figure 25 displays historical hydrothermal-explosion sites identified through a literature search. As with the prehistoric craters and deposits, the historical eruption sites are concentrated within the caldera and the Norris-Mammoth corridor. Notably, the Upper and Lower Geyser Basins hosted many of the observed events. Appendices 1 and 2 provide descriptions of some of the historically observed explosions and the prehistoric explosion deposits studied.

The end result of most hydrothermal explosions is a crater, commonly water-filled, surrounded by a berm of fragmental rocks with steep inward slopes and gentler outer slopes. The deposits generally comprise pieces of hydrothermally altered or mineralized materials such as 
siliceous sinter, mud, breccia, and subsurface lithologies such as lake, beach, or glacial sedimentary rocks and rhyolitic rocks from deeper levels.

The individual fragmental deposits are quite varied and reflect the stratigraphy of underlying rocks and the depths of rocks evacuated by the explosion, and they commonly record complex, multiple-event histories. Silica, in the forms of quartz, chalcedony, opal, and amorphous silica, is the most common cement of the explosion breccias and cross-cutting veins, but pyrite, calcite, and zeolites also are common hydrothermal minerals.

The complexity of the deposits implies repeated explosion events over a wide range of scales, with lithic fragments being ejected, falling back into or adjacent to the vent, and being cemented with silica to form breccias. Multigenerational heterolithic breccias also are common, indicating an extended process of repeated brecciation and hydrothermal cementation that likely occurs in hydrothermal systems well below the explosion vents (Keith and Muffler, 1978; Morgan and others, in review).

\section{Factors contributing to hydrothermal explosions}

Several factors contribute to the likelihood of hydrothermal explosions. Prior to the eruption of Porkchop Geyser in 1989, Fournier and others (1991) had interpreted chemical indicators as showing that the temperature of the water feeding the hot-spring pool had been increasing with time. Increased temperature of the deep water would have had two primary effects. First, it would have increased the amount of boiling and therefore steam production as the water rose towards the surface. Second, it would have increased the amount of silica in the ascending water and thus the supersaturation of silica as the water cooled during its rise. The first factor would have increased pressure in the system as the steam/liquid ratio in the subsurface increased in the relatively constant-volume system. The second factor would have decreased permeability in the geyser's conduit, potentially causing a decrease in the rate at which water could flow through the system. Thus, increased heat to the system increased the likelihood of pressurization and hydrothermal explosions.

Another influence on the likelihood of hydrothermal explosions is the depth of the vaporliquid interface above a liquid-dominated geothermal reservoir (fig. 23), as this depth controls the pressure of any vapor reservoir near the surface. If rocks of low permeability overlie a vapordominated region, then the pressure can rise if any or several of the following things should change: a) increased heat supplied to the system, b) increased amount of gas or steam rising through the system, or c) reduced ground water recharge to the system causing the geothermal water table to fall. Any of these factors would cause an increase in the thickness of the steam reservoir, resulting in greater pressures transferred toward the surface through the vapor/steam reservoir. This process occurs commonly at geothermal wells, where gas must be "bled off" to prevent displacement of water and lowering of the water level within the well. If gas or steam is allowed to accumulate in idle geothermal wells, the results can be disastrous. Because the ground surface at Yellowstone is generally permeable above vapor-dominated areas, allowing abundant gas flux (Werner and Brantley, 2003), this mechanism may not be a leading cause of explosions at Yellowstone but might be so on occasion.

Rapid pressure reduction is commonly invoked as a cause of hydrothermal destabilization. Withdrawal of fluids from geothermal wells is documented to have lowered subsurface pressures and induced boiling and hydrothermal explosions in geothermal fields (Scott and Cody, 2000). Earthquakes, deglaciation, or lake drainage all could cause sufficient depressurization of a boiling aquifer to cause hydrothermal explosions at Yellowstone (Muffler and others, 1971; Morgan and others, in review). Bargar and Fournier (1988) demonstrated that parts of the geothermal reservoir were superheated by $20-50^{\circ} \mathrm{C}$ following deglaciation, at about 12 to $15 \mathrm{ka}$. This is presumably because while glacial ice was present, areas beneath the ice-rock contact were pressurized 
compared with ice-free conditions, allowing a higher boiling temperature for $\mathrm{H}_{2} \mathrm{O}$. After deglaciation, considerable boiling would be necessary to re-equilibrate the water column to the new, lower-pressure conditions. Although this temporary instability would not likely be a direct trigger for hydrothermal explosions, it could be a possible contributing factor; whether any explosions resulted directly from deglaciation and attendant depressurization is not known.

Earthquakes, extremely common at Yellowstone, are also known to have strong effects on geothermal features (Watson, 1961; Marler, 1964; Marler and White, 1975; Husen and Smith, 2004). Some of the large prehistoric hydrothermal explosions could have been triggered by destabilization due to passage of large-amplitude seismic waves that dynamically increase local stress in hydrothermal reservoirs.

Although several factors can be identified as potential triggers for hydrothermal explosions at Yellowstone, the reality is that there are only sparse observational or scientific monitoring data on past explosive events. Geologic evidence for triggering mechanisms for past events is rare and ambiguous though current studies are aimed at detecting such information where it may exist.

\section{Toxic gases}

After steam, carbon dioxide $\left(\mathrm{CO}_{2}\right)$ is the most common constituent of volcanic gas and can be emitted in sufficient quantities to pose a hazard at many volcanic and geothermal systems around the world (Baxter, 2005). After subtracting steam, $\mathrm{CO}_{2}$ typically constitutes 95 to $98 \%$ of the gas emitted from Yellowstone's fumaroles and bubbling pools (Werner and Brantley, 2003).

Carbon dioxide is non-toxic in low concentrations and makes up about $0.038 \%$ of the Earth's atmosphere. However, because it is about $50 \%$ heavier than normal air, it can accumulate to much higher concentrations in soils and low or protected areas such as valleys and caves. Carbon dioxide concentrations of $>10 \%$ are toxic to humans and animals. When air contains over $20-30 \% \mathrm{CO}_{2}$, even a few breaths can quickly lead to unconsciousness and death from acute hypoxia, severe acidosis, and respiratory paralysis (Hill, 2000). Hypoxia is a condition in the body resulting from the displacement of oxygen such that it inhibits normal metabolism. Acidosis occurs when $\mathrm{CO}_{2}$ acidifies the blood, causing irreversible cellular damage. In the Yellowstone region, the local concentration of $\mathrm{CO}_{2}$ to potentially toxic levels is generally only temporary and is restricted to confined or topographically low areas of hydrothermal activity, generally under windless conditions.

Volcanoes commonly emit acid gases like sulfur dioxide $\left(\mathrm{SO}_{2}\right)$ and hydrogen chloride $(\mathrm{HCl})$. For example, at the volcanoes Kilauea in Hawaii and Masaya in Nicaragua, these acid gases form aerosols that are a chronic hazard to both local vegetation and human populations (Baxter, 2005). At Yellowstone, the hydrothermal system and its host rocks act as a buffer that absorbs and neutralizes acid gases, forming hydrogen sulfide $\left(\mathrm{H}_{2} \mathrm{~S}\right)$ gas and soluble sodium chloride. Additional $\mathrm{H}_{2} \mathrm{~S}$ may rise directly off the magma. The concentration of $\mathrm{H}_{2} \mathrm{~S}$ is typically about 20 to 200 times less than that of $\mathrm{CO}_{2}$, but its toxicity is much greater. Though $\mathrm{H}_{2} \mathrm{~S}$ has an extremely strong "rotten-egg" odor at levels of only a few parts per billion (ppb), concentrations of more than $10 \mathrm{ppm}$ in the air will rapidly deaden the human sense of smell to its presence (Mandavi, 2005). Concentrations of $100 \mathrm{ppm}$ can cause severe eye and throat irritation, and at concentrations exceeding $700 \mathrm{ppm}$ loss of consciousness and death can occur rapidly. Hydrogen sulfide forms a complex bond to iron in mitochondrial cytochromes, thereby arresting aerobic metabolism in an effect similar to cyanide toxicity (Milby and Baselt, 1999).

\section{The Hazards}

The geologic setting, geophysical activity, and hydrothermal systems reviewed above provide the framework within which to consider potential hazards arising from any future volcanic, 
hydrothermal, or gas-emission activity. For each of these categories of potential hazards, discussion is organized in terms of different types of activity that might develop as the Yellowstone magmatic-tectonic-hydrothermal system continues to evolve.

\section{Volcanic-eruption hazards}

As is characteristic of many large continental magmatic systems, eruptive activity in the Yellowstone Plateau volcanic field is highly episodic and involves long periods of time between eruptions; many of the eruptions are quite large. Such systems are particularly difficult to evaluate in terms of the probabilities of hazardous events and the consequent risks to people and resources. In order to bring some coherence to this discussion, it is organized by considering first the smaller, more likely future volcanic eruptions and proceeding to the larger and potentially most destructive but least likely events.

\section{Basaltic eruptions}

As noted earlier, basaltic lavas have erupted around the margins of the active, mainly rhyolitic Yellowstone Plateau volcanic field throughout its evolution. The absence of basalts from within the rhyolitic source areas is interpreted to reflect the trapping within the crust of any basaltic magmas that might have intruded from zones of partial melting in the upper mantle beneath crustal rhyolitic magmas of lower density (Christiansen, 2001). Only after about a million years have basalts erupted through the cooled, crystallized, and fractured upper-crustal magmatic sources of the first and second rhyolitic cycles; no basaltic vents, however, occur within the third-cycle Yellowstone caldera. A few small outcrops of basalt do occur on the northwest caldera wall near Purple Mountain (Christiansen and Blank, 1974), but they are erosional remnants of lavas that flowed down the steep slope from vents farther north. Additionally, some rare quenched inclusions of basaltic magma were found within the basal part of the rhyolitic West Yellowstone flow near the crest of the Madison Plateau west of Little Firehole Meadows (R. L. Christiansen and H. R. Blank, Jr., unpubl. data), suggesting that basaltic magmas from lower-crustal levels might have played a role in mobilizing some intracaldera rhyolitic magmas for eruption.

Most postcaldera basalts of the Yellowstone area are glaciated erosional remnants of oncelarger flows (fig. 10). Extrapolation to the likely outlines of initial distributions suggests that most individual basaltic eruptions covered areas of less than about $5 \mathrm{~km}^{2}$ and did not exceed $0.1 \mathrm{~km}^{3}$ in volume. The largest single basaltic flow field, however, the Falls River Basalt, extends from the southwestern caldera margin to Henrys Fork of the Snake River, a distance of about $60 \mathrm{~km}$. The Falls River Basalt flow field may have covered $900 \mathrm{~km}^{2}$ and may account for an eruptive volume of nearly $20 \mathrm{~km}^{3}$. At least two vents and possibly more fed the flow field, only one of which is now exposed (fig. 10). The next largest basaltic flow field near Yellowstone National Park, the Gerrit Basalt covering about $100 \mathrm{~km}^{2}$ in the area of Island Park, west of Yellowstone, erupted from at least 13 vents. Basalts cover the Eastern Snake River Plain west of Island Park, and at least 4 vents for basalts of the Snake River Group are within or immediately adjacent to the basin of Island Park (Christiansen, 1982).

The postcaldera basalts of the Yellowstone region-generally pahoehoe flows - are mainly olivine tholeiites having a range of $\mathrm{K}_{2} \mathrm{O}$ contents (but commonly $<0.5 \%$ ). Lavas producing such flows would be expected to have low viscosities and to erupt rapidly. Probably most of the basalts erupted in events lasting no more than a few weeks to a few months, but a large flow field like the Falls River Basalt might have accumulated in multiple eruptions, each lasting many months. Most of the recognized basaltic vents are localized agglutinated scoria accumulations or small lava shields, but some basalts may have originated as dike-fed fissures. A few formed cinder cones. 
A total of 33 postcaldera basaltic vents (fig. 10) have been recognized or inferred in the area immediately surrounding the Yellowstone caldera (Christiansen, 2001; Smith and Bennett, 2006). Of these, 17 are within or adjacent to the Island Park basin; the others are scattered around all sectors of the Yellowstone-caldera margin. Because of their generally scattered distribution, most of the vents probably remain preserved at the surface, but some might have been buried by younger materials or not recognized during geologic mapping. If it is assumed that 80 percent of the actual vents have been recognized, there could have been as many as 40 basaltic eruptions around the periphery of the Yellowstone caldera in the past 640,000 years. Of these about half occurred in Island Park. No postglacial basaltic eruptions have been recognized, indicating that none has occurred within the past 16,000 years.

On the basis of the foregoing, the average period between basaltic eruptions in the area around Yellowstone National Park during post-Lava Creek time is about 16,000 years. The average annual probability (i.e., the number of events divided by the time period, in years, during which they have occurred) of a basaltic eruption occurring somewhere around the periphery of the Yellowstone Plateau volcanic field is therefore $6 \times 10^{-5}$. However, it is unclear whether the basaltic eruptions, like some of the Yellowstone rhyolitic eruptions, may have been clustered in time; if so, the long-term average recurrence period may have little direct bearing on future eruption probabilities. The most likely location for any such future basaltic eruption is within the basin of Island Park but could be anywhere else within a band about $40 \mathrm{~km}$ wide surrounding the Yellowstone caldera. Any such eruption is most likely to last between a few weeks and several months. It is possible but unlikely that basalt could erupt from within the caldera; if such an event were to occur, however, it would signal the demise of the large Yellowstone-caldera rhyolitic magma chamber.

The principal hazard likely to result from a basaltic eruption around the periphery of the Yellowstone caldera would be coverage of an area of several square kilometers by lava, one to a few tens of meters thick. In addition, basaltic ash and cinders from the eruptive vent might blanket areas of many hundreds of square kilometers to depths of a few meters to a few centimeters, decreasing in thickness outward from the vent in directions determined by the prevailing winds. If a basaltic vent were to emerge from beneath shallow water or a large area of saturated ground, phreatomagmatic eruptions could produce pyroclastic surges within the proximal area that could blast down trees and cause other similar destruction.

In addition to any primary hazards of lava inundation and ash blanketing, there are likely to be secondary hazards from any basaltic eruption in the Yellowstone region. In particular, such an event would be likely to start fires around an advancing flow front, particularly under dry conditions. Debris flows or floods could be triggered by the melting of any significant snow pack or by temporary blockages of major drainages and subsequent release of floodwaters as the blockage was undermined or overtopped by rising waters.

Given the ongoing YVO monitoring program, it is likely that there would be recognizable premonitory indicators of any impending basaltic eruption. In particular, multiple shallow earthquake swarms focused in a small, probably linear area would be likely to be followed or accompanied by volcanic tremor, as has been observed at many basaltic volcanoes as they prepare to erupt. It is likely that surface ground cracks would open in the immediate stages prior to any basaltic eruption as a dike approached the surface. Because YVO deformation monitoring is focused on the Yellowstone caldera, initial uplift associated with the shallow intrusion of basaltic magma peripheral to the caldera might not be recognized quickly.

The emission of magmatic gases to the surface would be a major indicator of impending eruptive activity but might be quite difficult to recognize in the presence of Yellowstone's massive hydrothermal system, which tends to scrub out magmatic gases passing through it (Symonds and others, 2001). Nevertheless, any locally increased emissions of $\mathrm{CO}_{2}$ or $\mathrm{H}_{2} \mathrm{~S}$ should be monitored 
closely; any appearance of $\mathrm{SO}_{2}$, presently absent at Yellowstone, would be especially indicative that the hydrothermal system was becoming dried out by shallow magmatic intrusion. Even without $\mathrm{SO}_{2}$, significant localized increases in the ratio of sulfur gases to carbon gases would suggest the possibility of magmatic gas reaching shallow subsurface levels.

Because no basaltic eruptions have occurred in more than 16,000 years at Yellowstone, there are no well-established magmatic pathways. Thus, it is most likely that premonitory seismicity would be sufficiently prominent and of long enough duration to allow temporary monitoring of ground deformation and gas emission to provide additional information for interpreting possible locations and the nature of any such eruptive event. Among the earliest indicators might be relatively deep long-period seismicity. The most immediate precursors probably would occur as a shallow intrusion entered the hydrothermal system, generating very active short-period seismicity and possibly hydrothermal explosions. However, the distinction between an impending basaltic or small rhyolitic eruption might be difficult to evaluate before the initial venting.

Because the basaltic lava flows of Yellowstone are virtually all tube-fed pahoehoe, their advance would probably be slow enough to allow mitigating measures to be taken except, perhaps, in areas close to erupting vents.

\section{Large rhyolitic eruptions}

At least 17 large rhyolitic lava flows, most of them with volumes of $10 \mathrm{~km}^{3}$ or greater, have erupted within the Yellowstone caldera during about the past 170,000 years (Christiansen, 2001). Stratigraphically they belong to the Central Plateau Member of the Plateau Rhyolite. Each of these lava flows extruded through one of two linear vent zones that cross the caldera along the extrapolated positions of extracaldera tectonic fault zones (figs. 8, 11), and activity has been essentially contemporaneous on both zones. The largest of these lava flows cover areas greater than $350 \mathrm{~km}^{2}$ and have volumes greater than $30 \mathrm{~km}^{3}$ (table 2). The constructional topography formed by these flows is represented by the Pitchstone, Madison, and Central Plateaus (figs. 1 and 26). The Pitchstone-Madison Plateau alignment lies on the extrapolated position of the Teton normal-fault zone (fig. 11) and extends to the southwest edge of the tectonic West Yellowstone basin (fig. 8). The Central Plateau alignment (fig. 8) lies on an extrapolation of both the Sheridan normal-fault zone (fig. 11) and the extracaldera Norris-Mammoth corridor (fig. 10).

As these young intracaldera rhyolite flows are petrographically, chemically, and isotopically distinct from early intracaldera rhyolites (Hildreth and others, 1984; Hildreth and others, 1991) and have an age range separated by about 80,000 years from the youngest known earlier intracaldera flows, they are considered here together as a group separate from the older postcaldera lavas. The hazard potential for a possible future intracaldera eruption may be best reflected in the characteristics of this group of voluminous rhyolites of $\sim 170 \mathrm{ka}$ and younger.

Available K-Ar and ${ }^{40} \mathrm{Ar} /{ }^{39} \mathrm{Ar}$ dating of rhyolitic flows of the Central Plateau Member (table 2; figs. 9, 26) indicates that they erupted in a few major episodes. The earliest of these episodes probably began with the Mallard Lake flow that erupted from the Central Plateau vent alignment and covered the eastern part of the Mallard Lake resurgent dome (Christiansen, 2001). It was either accompanied by or immediately followed by renewed uplift of the Mallard Lake dome. Subsequent eruptions, within a period of less than 10,000 years, produced the Dry Creek, West Thumb, and Mary Lake flows along the Central Plateau vent zone and the Buffalo Lake flow along the Madison Plateau vent zone (fig. 9). Additional rhyolitic lavas, now buried, may well have erupted during this time from either or both of those zones. In addition to these lavas, at least one major pyroclastic eruption occurred along the Central Plateau vent alignment to produce the tuff of Bluff Point. Although its volume cannot be reconstructed convincingly because of erosion and burial by younger lavas, eruption of this pumiceous pyroclastic unit was sufficiently large to 
produce a source caldera $10 \mathrm{~km}$ in diameter, now represented by West Thumb, the westernmost basin of Yellowstone Lake (fig. 8). The eruptive volume almost certainly was several tens of $\mathrm{km}^{3}$. The actual time span represented by eruptions of these oldest units of the Central Plateau Member is not defined precisely. The nominal span of weighted-mean ages for the dated lava flows and tuff of this group is $173 \pm 11$ to $160 \pm 3 \mathrm{ka}$, but disagreements between individual age determinations and the stratigraphic order interpreted from geologic mapping suggest that some of the isotopic ages are incorrect. The group mean age and standard deviation of the individual weighted-mean isotopic age determinations on all of these units is $167 \pm 5$ thousand years, and all the weighted-mean ages of the individual units of this group overlap that range. Thus, the range might be a closer representation of the actual span of time involved in erupting them than the nominal span of individual age determinations.

Distinct in time but only shortly after the first group of eruptions along the Central Plateau vent alignment (fig. 8) were the Aster Creek, Elephant Back, Spruce Creek, and Nez Perce Creek lava flows (fig. 9). The undated Spring Creek flow may have vented on the Madison Plateau vent alignment during this same episode. At least one significant pyroclastic unit, the tuff of Cold Mountain Creek, is also interstratified among lavas erupted along the Madison Plateau alignment although its source location is not known. This tuff may represent early pyroclastic activity from the vent for a large lava flow of the Madison Plateau. The age of this group of rhyolitic eruptions is about $150 \pm 5 \mathrm{ka}$, calculated similarly to that of the earlier group.

Another relatively brief episode of large-volume rhyolitic eruptions within the Madison Plateau vent zone formed the Summit Lake, Bechler River, and West Yellowstone flows (fig. 9); the smaller Douglas knob and Trischman Knob domes also probably erupted during this episode, possibly as late-stage vent domes of the Bechler River flow (Christiansen, 2001). The area covered by flows of this age group is smaller than for the older groups, and all flows erupted during this sequence probably are represented by surface exposures. Nominal weighted-mean K-Ar ages of these lavas range from $124 \pm 10$ to $114 \pm 1 \mathrm{ka}$, but just as for the older groups, stratigraphic relations suggest that the actual time span of eruption was short. A mean age and standard deviation of the individual weighted-mean age determinations on these flows is $118 \pm 5 \mathrm{ka}$.

Yet another episode of relatively large rhyolitic lava eruptions vented along the Central Plateau at about 102-103 ka, producing the Hayden Valley and Solfatara Plateau flows (fig. 9). The age of these flows, calculated similarly to those of the older groups, is $103 \pm 1 \mathrm{ka}$.

The most recent episode of large intracaldera rhyolitic lava eruptions is represented by the adjacent Grants Pass and Pitchstone Plateau flows (fig. 9), with weighted-mean ages of $72 \pm 3$ and $79 \pm 11 \mathrm{ka}$, respectively. Both flows may well represent a single eruptive event, the linear vent for the Grants Pass flow representing an early dike phase, and the Pitchstone Plateau flow issuing from a longer-lived central-vent phase. The weighted-mean age and standard deviation of these flows is $76 \pm 5 \mathrm{ka}$.

Several factors suggest a model for systematic evolution for rhyolitic eruptions of the Central Plateau Member that may have implications for related volcanic hazards. Volumes of the Central Plateau lavas (table 2) were calculated from geologic maps using a cut-and-fill estimator in ArcInfo, a Geographic Information System; those calculations proceed by estimating the original extent and a computer-generated extrapolation of a flat bottom to each flow, resulting in a minimum-volume estimate and, thus, probably an underestimate of the total volume of all the flows. The aggregate volume of the oldest group, at $167 \pm 5 \mathrm{ka}$, is by far the greatest, at least 138 $\mathrm{km}^{3}$. That volume, however, is possibly even greater, $\sim 400 \mathrm{~km}^{3}$ as suggested by a separate calculation of the total volume for all Central Plateau Member lavas of $>600 \mathrm{~km}^{3}$, with the difference between these calculations listed as "unobserved units" in table 2. (An earlier estimate of the total volume of the Central Plateau Member by Christiansen (2001) was $900 \mathrm{~km}^{3}$ ). The aggregate volume of the second group of lavas, at $150 \pm 5 \mathrm{ka}$ is at least $62 \mathrm{~km}^{3}$, and that of the next 
group, at $118 \pm 5 \mathrm{ka}$, is about $86 \mathrm{~km}^{3}$. The volume of the $103 \pm 1-\mathrm{ka}$ pair is about $9 \mathrm{~km}^{3}$, and that of the youngest pair, at about $76 \pm 5 \mathrm{ka}$, is about $70 \mathrm{~km}^{3}$. (These volume estimates do not include the tuffs of Bluff Point and Cold Mountain Creek, for which relevant data are inadequate). Thus, large volumes of rhyolite erupted in episodes separated by roughly 15,000 to 30,000 years from each of the two linear extensional zones across the Yellowstone caldera where they intersect the caldera ring-fracture system. More than 70,000 years have ensued since the latest eruptions.

Isotopic analyses of oxygen on most stratigraphic units of the Yellowstone Plateau volcanic field were reported by Hildreth and others (1984). Oxygen, being by far the most abundant chemical element in any igneous rock, is particularly useful in tracing processes that affect the magmatic system as a whole. Although quartz phenocrysts in the oldest rocks of the volcanic field have $\delta^{18} \mathrm{O}>7 \%$ - more or less typical igneous values - quartz in lavas erupted shortly after the first-cycle caldera-forming eruption had sharply depleted $\delta^{18} \mathrm{O}$, to values as low as $\sim 4 \%$, resulting from massive assimilation of low $-{ }^{18} \mathrm{O}$ hydrothermally altered rocks or meteoric water. Lavas and tuffs erupted over nearly the next 1.5 million years recovered gradually in $\delta^{18} \mathrm{O}$ indicating that infusions of magma from greater depths successively augmented the upper-crustal magma chamber; by the time of the climactic Lava Creek Tuff eruption at $639 \pm 2 \mathrm{ka}, \delta^{18} \mathrm{O}$ had recovered to values in quartz as high as $6.8 \%$. Formation of the Yellowstone caldera, however, was again accompanied by massive assimilation of low $-\delta^{18} \mathrm{O}$ materials; quartz in early intracaldera lavas drastically reduced in $\delta^{18} \mathrm{O}$ to values as low as $\sim 1 \%$. Since then, ${ }^{18} \mathrm{O}$ in intracaldera lavas and tuffs has again gradually recovered with successive additions of high- $\delta{ }^{18} \mathrm{O}$ magma; during the intracaldera eruptions of $\sim 170,000-70,000$ years, $\delta^{18} \mathrm{O}$ in quartz has increased irregularly from $\sim 4.6$ to $5.1 \%$.

Trace-element compositions of the Central Plateau Member lavas became progressively more evolved with time (Hildreth and others, 1991; Vazquez and Reid, 2002). Vazquez and Reid (2002) showed that zircons in the Central Plateau Member lavas have ${ }^{238} \mathrm{U} /{ }^{230} \mathrm{Th}$ model ages that generally range from their eruption ages back to about $200 \mathrm{ka}$-compared to U-Pb zircon data from the Lava Creek Tuff that show its magma to have been generated $<100,000$ years before the caldera-forming eruption (Bindeman and others, 2001). Thus the Central Plateau Member lavas can be regarded as representing an incrementally augmented body of upper-crustal rhyolitic magma beneath the Yellowstone caldera. Furthermore, these late postcaldera lavas show evidence of progressive differentiation throughout the time of their eruption. The ratio $\mathrm{Rb} / \mathrm{Sr}$, for example, generally increases with decreasing ages of the flows. Vazquez and Reid (2002) modeled mineral and whole-rock trace-element chemistry as being consistent with the sequence of lavas postdating formation of the Yellowstone caldera representing at least $40 \%$ sanidine-dominated fractional crystallization of the residual magma body. This magma, initially low in ${ }^{18} \mathrm{O}$, was augmented progressively by infusions from deeper magma. Through most of this time, in the Vazquez and Reid model, the lavas erupted intermittently while sanidine and other major phenocryst phases fractionated progressively to accumulate below in a crystal-liquid mush but zircon did not. In fact, it may well be that any preexisting zircon and plagioclase were resorbed in the residual magma. After about $120 \mathrm{ka}$, new zircon crystals grew in magmatic liquid separated from the underlying mush for as long as 50,000 years before eruption to produce the youngest of the Central Plateau lavas, the Pitchstone Plateau flow.

The successive eruption of these voluminous, progressively more evolved lavas from a single magma body suggests a model in which magma is augmented incrementally but slowly crystallizes and differentiates in a postcaldera Yellowstone magma chamber while the chamber roof is progressively cooled from the top by hydrothermal circulation. A mixture of magmatic liquid and crystals is envisioned to remain in the chamber until fractures driven by regional tectonic extension in the cooling chamber roof become large enough to extend downward toward the level of magma storage. These fractures then enable the intrusion of rhyolitic dikes, allowing the magma 
to extrude and erupt to the surface. The intrusions heat the chamber roof, reducing its elastic strength, sealing and inhibiting further development of large, deep fractures, and tending to retard further eruption. Only as hydrothermal circulation again cools the rocks of the chamber roof can fractures of sufficient size again start to develop and promote renewed tapping of liquid from the magma chamber, renewed diking, and surface eruption. With time, magmatic liquid in the chamber continues to differentiate, but smaller volumes remain sufficiently liquid to allow mobilization and eventual eruption. Thus, the rhyolites erupt in episodes of slightly more chemically evolved compositions. This model implies that any magmatic increments introduced into the upper-level chamber between $\sim 170$ and $70 \mathrm{ka}$ intruded at a rate lower than the rate of differentiation within the magma body.

Renewal of large rhyolitic eruptions within the Yellowstone caldera would present two major classes of hazards, explosive pyroclastic ejections and effusive lava eruptions. The initial phases of an eruption would undoubtedly involve pyroclastic eruption through an opening vent. Pyroclastic deposits probably lie buried beneath each of the large Central Plateau Member flows but remain mostly unexposed. Their distal equivalents, however, have been recognized in sedimentary basins surrounding Yellowstone, perhaps including ash beds designated Hebgen Narrows and Natural Trap by Izett (1981). Pumiceous ash mapped as the tuff of Cold Mountain Creek may also represent pyroclastic materials erupted in vent-opening phases of one or more of the Central Plateau Member lavas. Burial by pumice lapilli and ash from such vent-opening eruptions could be widespread and locally as thick as many meters. Pyroclastic flows could devastate areas of many tens of square kilometers. Subsequent lava extrusion could last many years, covering areas as great as $350-400 \mathrm{~km}^{2}$ to thicknesses of tens or hundreds of meters and volumes of 5 to more than $50 \mathrm{~km}^{3}$. Because such voluminous rhyolitic lava flows are unprecedented in the global historical record and their extrusion rates may be considerably greater than those of observed smaller flows, the actual length of time that an individual eruption might continue is uncertain. Certainly no infrastructure in areas affected by such lavas would survive.

Note should also be taken here of the tuff of Bluff Point, the only voluminous ash-flow tuff of the Central Plateau Member; its eruption resulted in formation of the 10-km caldera now represented by the West Thumb. The Bluff Point eruption was characterized by ejection, not only of pumice, ash, and small lithic fragments, but also of vitrophyric lava blocks as large as $1 \mathrm{~m}$ and possibly involved copious amounts of water from a predecessor of Yellowstone Lake. Based on this example, it is reasonable to suggest that any future voluminous rhyolitic eruption within or immediately adjacent to Yellowstone Lake might have the potential to produce an explosive pyroclastic eruption, much smaller in volume than a major caldera-forming event like the Lava Creek Tuff but nevertheless capable of producing high-speed flows of hot ash, rhyolitic debris, and volcanic gas that could affect virtually all of the Yellowstone Plateau area and produce regionally widespread finer downwind ash.

Secondary hazards associated with large intracaldera rhyolitic eruptions could include wildland fires, disturbed drainages, and possibilities of catastrophic flooding, and they could be especially severe and widespread given their great volumes. In particular, if a large-volume lava flow should displace a considerable volume of Yellowstone Lake, overflow could inundate large parts of the Yellowstone River drainage. Other large drainages could be impounded by lava, then released as catastrophic floods overtopped or undermined the lava dams.

Estimating probabilities for one or more large intracaldera rhyolitic eruptions involves considerable uncertainty. Considering that 17 known voluminous lava eruptions and 2 moderately large pyroclastic eruptions are documented and that additional flows probably are buried within the caldera, the raw probability might be estimated on the basis of approximately 25 events between about 170,000 and 72,000 years ago, an average intereruptive period of about 3900 years during that time. Alternatively, if it is assumed that the probability of such an eruption has remained 
uniform from $\sim 170 \mathrm{ka}$ to the present, the average period between eruptions would be 6800 years, the latest of which was $\sim 72,000$ years ago, or an annual probability of $1.5 \times 10^{-4}$. Clearly, however, such calculations are misleading. The voluminous eruptions were highly episodic, with numerous events occurring within periods of a few thousand years and longer periods of $\sim 12,000$ to 38,000 years ensuing without eruption and about 72,000 years since the latest of them. Furthermore, generally decreased numbers of eruptions in successive episodes, a doubling of the post-eruptive interval compared to the longest previous intereruptive intervals, and the fact that the latest of the five eruptive episodes was possibly a single voluminous event might even suggest that the repeating cycle has ended.

The foregoing calculated probabilities are based implicitly upon the assumption that the probability of an eruption occurring within a given time does not depend upon the time elapsed since the last previous eruption (statistically a Poisson, or simple exponential process). Because the large intracaldera eruptions of about the past 170,000 years are clustered in time, however, a more meaningful probabilistic calculation might be based upon a different statistical basis, a mixed exponential process (Cox and Lewis, 1966; Nathenson, 2001). Because of the isotopic evidence for reorganization of the magma at about $200 \mathrm{ka}$ and distinct changes in eruptive behavior and petrologic characteristics of intracaldera lavas since about $170 \mathrm{ka}$, only the time since $170 \mathrm{ka}$ is considered in the following analysis. (A complete discussion of this analysis and the relevant figures is given in appendix 3; only the important conclusions are summarized here).

The chronology for all known Yellowstone intracaldera eruptions since 170 ka is shown versus event number in figure 27 . Because of uncertainties in the ages of these eruptions, this figure shows three possible models for the ages for individual lava flows within each episode. Intereruptive intervals during certain periods are short, averaging less than $8 \mathrm{ky}$, and may be much less than that. There are several longer interruptions of activity: one is $38 \pm 4$ ky (thousand years), another is $30 \pm 6 \mathrm{ky}$, and two others are $12 \pm 6 \mathrm{ky}$. The resulting probability distribution (fig. 28) illustrates this behavior; the mixed exponential model curve matches the data well.

Using the mixed exponential probability distribution, the conditional probability that an intracaldera lava eruption will occur in the next year (fig. 29) decreases as the time since the last eruption increases, changing very little after about $20 \mathrm{ky}$. The mixed exponential probability of an intracaldera rhyolitic lava eruption in the next year, $\sim 72 \mathrm{ka}$ after the last eruption, is equivalent to an annual rate of $5 \times 10^{-5}$ or a recurrence rate of 1 in 20,000 years.

In addition to the probability of an eruption occurring in a given time, an important consideration is its likely size. Figure 30 shows the probability of a lava eruption within the caldera having a volume greater that any particular value, based upon volumes estimated for the 19 known late intracaldera lava flows or domes (table 2). The data are logarithmic with volume over most of the range, with large-volume lava flows more probable in the caldera than smaller ones. The probability that the next intracaldera lava flow will have a volume greater than $5 \mathrm{~km}^{3}$ is about $60 \%$; the probability of a volume greater than $10 \mathrm{~km}^{3}$ is about $40 \%$.

If a large intracaldera rhyolitic eruption were to occur, there would almost certainly be significant premonitory indications. Seismic swarms would probably be concentrated in any area of diking as magma rose from the magma chamber toward the surface. Such seismicity would most likely embrace the entire thickness of the brittle part of the crust above the chamber and might well display a pattern of decreasing focal depths with time. Furthermore, an initial intrusive phase would probably be indicated by a linear array of epicenters although they might or might not centralize toward a smaller area before the opening of an eruptive vent. Surface deformation should be readily detectible, and the volume of localized inflation-distinguished from such areally generalized inflation or deflation as measured within the caldera in recent decades-would likely presage the arrival of lava at the surface. Vent opening might well involve the local ground water system to produce phreatic or phreatomagmatic explosions. Initial pyroclastic eruption could 
extend to stratospheric heights, and its duration and magnitude might be considered as indicative of the volume of possible subsequent lava extrusion.

\section{Small rhyolitic eruptions}

The possibility of future rhyolitic lava eruptions in the Yellowstone system involves two more or less distinct scenarios. In addition to the large intracaldera eruptions just discussed, relatively small eruptions (a few cubic kilometers or less) might occur either within or outside the Yellowstone caldera.

Most of the small postcaldera eruptions of rhyolitic lava have occurred at locations outside the Yellowstone caldera. Of the 13 such eruptions known (fig. 10), all but one vented north of the caldera, either in the Norris-Mammoth corridor or between the Madison River and the southern Gallatin Range. A single postcaldera rhyolitic lava flow erupted south of the caldera, near the south entrance to Yellowstone National Park (fig. 10). Most of these extracaldera rhyolites are volcanic domes with diameters of $0.5-2.5 \mathrm{~km}$ and volumes less than $0.5 \mathrm{~km}^{3}$. Only four are larger flows that cover between 2 and $20 \mathrm{~km}^{2}$ or have volumes as great as $4 \mathrm{~km}^{3}$.

Several of the small rhyolites are intimately associated with basalt that occurs both as quenched magmatic inclusions and larger masses within the rhyolite; the largest of these are the Gardner River and Grizzly Lake rhyolite-basalt mixed-lava complexes. Two rhyolites, the Obsidian Cliff and Crystal Spring flows, completely lack phenocrysts, indicating that they were emplaced at or above their liquidus temperatures; the Crystal Spring flow also contains abundant quenched magmatic basaltic inclusions near its base. These observations suggest a role for basaltic magma in mobilizing the rhyolitic magma for intrusion to shallow depths. Geologic, geochemical, and isotopic data show that the extracaldera rhyolites erupted from individual magma sources that were related to local basaltic magmas but unconnected to the large rhyolitic magma chamber beneath the Yellowstone caldera (Hildreth and others, 1984; Hildreth and others, 1991).

Although individual small rhyolitic eruptions have vented from several locations around the Yellowstone caldera, by far the greatest number erupted within the Norris-Mammoth corridor. All of those younger than about 170,000 years (table 1), equivalent in age to the youngest intracaldera rhyolites, are located either in the Norris-Mammoth corridor or near the South Entrance to Yellowstone National Park, within $25 \mathrm{~km}$ of the caldera margin. Unlike the major normal fault zones such as the Teton, Sheridan, and Hebgen Lake zones (fig. 11), faults in the Norris-Mammoth corridor are generally of small to moderate displacement. By contrast, the principal fault along which the east side of the Gallatin Range is relatively uplifted, had a net late-Cenozoic stratigraphic throw of about $2 \mathrm{~km}$. Nevertheless, it has been inactive during postglacial time or longer. It was suggested by Pierce and others (1991), that magmatic diking along the Norris-Mammoth corridor postdating the Lava Creek Tuff, both rhyolitic and basaltic, effectively takes up a significant proportion of the extensional strain that otherwise would be expressed in normal displacement on the fault zone bounding the east side of the Gallatin Range.

Two distinct types of primary hazards might be associated with a small rhyolitic eruption in the Yellowstone area. The initial vent-opening phase of such an eruption would almost certainly be an explosive ejection of rhyolitic pumice. Most of the coarser pumice would be deposited close to the vent, but finer ash probably would be dispersed downwind over distances of many kilometers. Thicknesses of the downwind deposits could range from several meters to a few centimeters or less. In addition, an explosive phase could generate pyroclastic flows, high-speed mixtures of hot ash and gas capable of devastating areas within several kilometers of the erupting vent. Ash falls could cover large areas and cause damage to structures, power lines, and machinery by loading them, especially if such an eruption should occur under wet atmospheric conditions. Water supplies also could be damaged by substantial ash falls. If pyroclastic flows occurred, they would be highly dangerous and destructive to the local environment or to any structures or people in the 
vicinity of the eruption. Such initial pyroclastic eruptions would likely last between a few hours and a few weeks but quite likely would be succeeded by extrusion of viscous rhyolitic lava to form a dome or small lava flow. Areas up to several square kilometers could be covered by lava tens of meters thick. Although the immediate area affected by the primary hazards of deep burial by pumice, ash, or lava might be relatively small, the slow extrusion of lava would be likely to continue for many months or even years. Structures would not be able to withstand the lava advance, and any nearby roads or other infrastructure would certainly be affected. Advance of the viscous rhyolitic lava would be much slower than for a basaltic eruption; most facilities could be safely evacuated, and some of them, as well as vehicles, could be relocated during advance of a typical flow front.

Secondary hazards from a small rhyolitic eruption would be likely to include fires started by contact with the extruding lava. Other secondary hazards might include flooding if drainages were temporarily blocked or subsequently released suddenly. Because of the relatively slow advance of such lavas, however, effective mitigation of such effects might be somewhat less difficult than for a rapidly advancing basaltic lava flow.

The probability of a small rhyolitic eruption outside the Yellowstone caldera is quite low. Fourteen have occurred in postcaldera time (Christiansen, 2001; Spell and others, 2004) with an average intereruptive period of about 46,000 years. During the past 170,000 years there have been 6 small extracaldera rhyolitic eruptions, equivalent to an average period of 28,000 years. Eruptions in the past 170,000 years have been larger, typically producing flows of several $\mathrm{km}^{3}$, in comparison to the domes of less than $0.5 \mathrm{~km}^{3}$ extruded earlier in the postcaldera history. Insufficient age data exist to evaluate any possible episodic behavior of these youngest eruptions. The average annual probability of a small extracaldera rhyolitic eruption in the Yellowstone Plateau volcanic field is small. Calculated on the basis of the entire postcaldera period, it probably is on the order of $2 \times 10^{-5}$; on the basis of the record of the past 170,000 years it would be about $4 \times 10^{-5}$. Although less probable, a similar small rhyolitic eruption might also be possible within the Yellowstone caldera as well as in the extracaldera zone. Such extrusions, for example, formed the Douglas Knob and Trischman Knob domes on the Madison Plateau though these might be late-stage vent domes related to the much larger Bechler River flow.

It might be difficult in the early stages to distinguish typical premonitory seismic, deformation, or gas-emission indicators of a small rhyolitic eruption from those for a basaltic eruption. Because of more viscous magma, uplift and tilting of the ground surface above a zone of intensifying swarm seismicity might likely be more pronounced for a rhyolitic eruption. Also, as such seismic signals are typically associated with subsurface separation of a gas phase from the magma, the time required for any relatively deep long-period seismicity that might develop could be longer for a viscous rhyolitic magma than for basaltic magma. Detecting any such signals might, however, require instrumentation sensitive to a broader frequency range than is currently available at Yellowstone, such as borehole strain meters.

\section{Large caldera-forming eruption}

Of all the possible eruptive hazards that might occur in the region of Yellowstone National Park, by far the least likely is that of another major caldera-forming pyroclastic eruption of $100 \mathrm{~km}^{3}$ or greater. Three such events have occurred in about the past 2 million years, each associated with a cycle of precaldera and postcaldera rhyolitic volcanism lasting on the order of a million years. In the Island Park area, west of the 639 \pm 2 -ka Yellowstone caldera, the older rhyolitic source areas have subsequently produced basaltic lava eruptions. In contrast, contemporaneous basaltic magmas surround the Yellowstone caldera, but none have erupted within the caldera. This pattern strongly suggests that the crust where rhyolitic magma chambers existed during the previous two major caldera-forming eruptions and their associated rhyolitic volcanism has cooled and solidified 
sufficiently to fracture and allow basaltic magmas to intrude from below, precluding the possibility of large volumes of eruptible rhyolitic magma remaining there. However, the great heat flow represented by the massive long-lived hydrothermal circulation system of Yellowstone (Fournier, 1989) as well as significant delays in seismic-wave travel times and wave attenuation imaged in the shallow crust beneath the Yellowstone caldera (Benz and Smith, 1984; Miller and Smith, 1999; Husen and others, 2004) strongly suggest the continued presence of magma. What remain most uncertain are (1) the percentage of melt in the remaining, partly crystallized magma, (2) its degree of interconnection, and (3) its potential eruptibility. The more than $600 \mathrm{~km}^{3}$ of highly differentiated magma that has erupted as lava flows within the caldera between $\sim 170$ and 72 ka represents a volume equivalent to a large caldera-forming eruption. Those eruptions perhaps partly degassed and depleted the magma sufficiently slowly without triggering voluminous pyroclastic eruptions that they may have rendered another major caldera-forming eruption from the present subcaldera chamber unlikely.

Despite the seeming improbability of another large caldera-forming eruption at Yellowstone, the severe consequences of any such eruption, if one should occur, render it important to consider its potential hazards. The distribution of basalt around the Yellowstone caldera, as noted above, would seem to restrict the area of potential accumulation of sufficient rhyolitic magma for any such eruption to the vicinity of the Yellowstone caldera. It might seem that propagation of the Yellowstone hotspot toward the northeast through late Cenozoic time (compare fig. 4) could make a future caldera-forming eruption more likely to occur northeast of the present caldera center. Indeed, crustal density is notably low, hydrothermal heat flow high, and seismic wave speeds slow in the area of Hot Springs Basin, $13 \mathrm{~km}$ northeast of the Sour Creek dome (fig. 7). These characteristics, however, probably are related to crustal changes associated with the deep vapor-dominated hydrothermal system of that area (Miller and Smith, 1999). The pattern of young postcaldera rhyolitic magmatism of the Central Plateau Member suggests the possibility (Christiansen, 2001) that, since $\sim 170 \mathrm{ka}$, rhyolitic magma could have been rejuvenated or remobilized beneath the western, or Mallard Lake, caldera segment in a manner analogous to the relation of the second-cycle Henrys Fork caldera to the older first-cycle Big Bend Ridge caldera segment (fig. 5). Although no particular site can be shown to be either more or less likely to be the source of any possible future voluminous pyroclastic eruption, only a site within or immediately adjacent to the present caldera seems reasonable for a large pyroclastic eruption at Yellowstone.

Spell and others (2004) and Smith and Bennett (2006) have suggested that the basaltic and rhyolitic volcanism of the Norris-Mammoth corridor postdating the Lava Creek Tuff represents an evolving magma chamber that could presage a new caldera-forming eruption from that area. That scenario, however, seems to be contradicted by several lines of evidence. Geochemical and isotopic data, especially ${ }^{18} \mathrm{O}$, show that all three caldera cycles of the Yellowstone Plateau volcanic field erupted from a continuously evolving shallow-crustal magma-storage system and that the magmas erupted in the Norris-Mammoth corridor are unrelated to them (Hildreth and others, 1984; Hildreth and others, 1991). Furthermore, volumes of rhyolite in that corridor are small, and basaltic magma was available for eruption continuously during eruption of those rhyolites, as indicated by the undated Osprey Basalt that fills deep canyons cut into the youngest dated basalt $(174 \pm 46 \mathrm{ka})$ as well as abundant quenched mafic inclusions in the 80-ka Crystal Spring rhyolite flow. Additionally, whereas geophysical indicators of inflation and deflation of the Yellowstone caldera are commonly coherent over the caldera area, the Norris-Mammoth corridor shows no comparable indications of systematic deformation or seismicity. These factors argue against any large-scale rhyolitic magma-storage sufficient to promote and sustain a caldera-forming eruption in the Norris-Mammoth corridor.

Although the probability of another major caldera-forming eruption at Yellowstone is extremely low, the hazards from any such eruption cannot be overstated. Once any such eruption 
began, it probably would proceed quickly to a climax, which would last for many days. Any caldera-forming eruption probably would begin at one or a few individual sites with plinian columns of hot volcanic ash rising into the stratosphere, and likely would spread to encompass a ring-fracture system encircling the newly collapsing caldera. Lacking historical precedents for such an eruption, the length of time that an initial plinian phase might last is uncertain and could be a few hours to many weeks. Once the eruption developed past the initial phase, areas within and adjacent to the eruptive source would be overrun quickly by lateral flows of mixed volcanic ash, rocks, and gases at temperatures of several hundred degrees Celsius and speeds of a hundred $\mathrm{km} / \mathrm{h}$ and greater as ash fall continued both within the source area and to great distances, even around the globe. Ash-accumulation rates estimated for the well-studied Bishop Tuff of eastern California, roughly comparable to the Lava Creek Tuff though approximately half its volume, indicate that the Bishop Tuff erupted continuously for several days (Wilson and Hildreth, 1997). A major calderaforming eruption at Yellowstone probably would have a similar duration. All structures and living things within the areas overrun by ash flows would be destroyed and possibly vaporized. The atmosphere above the eruption would be choked with pumiceous volcanic ash and lapilli, producing an extreme hazard to aviation, and the ash and associated fallout would quickly spread far beyond the eruptive area. Because of the complex patterns of upper-atmospheric wind circulation, there would likely not be a single simple plume of ash fallout in one downwind direction, but large parts of western and central North America might well be buried by ash falls, ranging from many meters in thickness within tens of kilometers of the eruption to many centimeters at continental distances (compare fig. 3). Fine ash and other particulates would circle the globe.

The possible secondary hazards from a potential large caldera-forming eruption at Yellowstone could themselves be greater than the primary hazards from other types of eruption. Suspended ash would continue to circulate in the upper atmosphere for many weeks, and could, together with volcanic gases associated with the eruption, affect global climate for several years. Reduced solar irradiation resulting from suspended ash and sulfuric-acid droplets could cool the lower atmosphere for several years, at least throughout the northern hemisphere and probably globally as well (Rampino and others, 1988). Other global climatic effects might last even longer, depending on the sensitivity of certain environments (Rampino, 1991), with possibly severe ecological consequences (Rampino and Ambrose, 2000). In addition, the primary ash blanket over large regions, especially of the Western United States, would be eroded by rainfall and surface drainage to be redistributed from higher areas into lower-lying places, mantling some of them with many meters of ash even where initial fall was only millimeters to centimeters thick. Many reservoirs would be silted up, some of them becoming unusable; some dams might fail as a result of overtopping by their reservoirs. Most of these secondary effects would be distributed over large regions, far from Yellowstone; the devastating primary effects would far outweigh them in the proximal area.

Although the probability of a large caldera-forming eruption at Yellowstone is exceedingly small, it is exceedingly difficullt to make a defensible quantitative estimate of that probability. As there have been three such eruptions in about the past 2,100,000 years, there are only two intereruptive periods from which to gauge any additional possible interval between the third and a potential fourth such event. The first interval, between the Huckleberry Ridge $(2.059 \pm 0.004 \mathrm{Ma})$

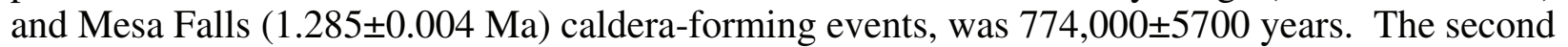
interval, between the Mesa Falls and Lava Creek (0.639 $\pm 0.002 \mathrm{Ma})$ events, was $646,000 \pm 4400$ years. A statement, widely repeated in popular media, regards such eruptions as occurring at Yellowstone "every 600,000 years" with the latest eruption having been "600,000 years ago". This is commonly taken to imply that another such eruption is "overdue". Such a statement is statistically indefensible on the basis of the extrapolation of two intervals. (Even the simple 
arithmetic average of the two intervals is 710,000 years, not 600,000 years). From the line of reasoning outlined here, the probability of a fourth large caldera-forming event at Yellowstone can be considered to be less than 1 in a million, below the threshold of hazards interest unless future premonitory phenomena, probably more severe than those recorded historically in caldera systems around the world (Newhall and Dzurisin, 1988), were to be recognized.

Premonitory indications of an impending major caldera-forming eruption at Yellowstone would include intense swarm seismicity, perhaps localized near the site of an impending outbreak, but initial indications might not be greatly different from those for a smaller eruption. A magma body large enough to sustain a major caldera-forming eruption would, however, be expected eventually to respond as a whole. By the time seismicity and ground fracturing spread to encompass a larger area, equivalent to a potential caldera and perhaps to outline a ring-fracture system, major eruption might already be well underway. Based upon the geologic record of the Lava Creek eruption, magma rising to shallow levels almost certainly would produce significant uplift of both a locus of possible outbreak and also a larger area of shallow rising magma. Quite possibly ground fracturing would accompany intrusion to shallow crustal levels and might even begin to outline a ring-fracture system (compare to figure 6). Magmatic gases venting to the atmosphere before any ash or lava were to erupt, including $\mathrm{CO}_{2}$, various sulfur species (but especially $\mathrm{SO}_{2}$ ), and halogens, might well be more evident and more copious from such a large shallow magma body as it ascends into the brittle upper-crustal zone than would be expected for a smaller body that might lead to a single central-vent rhyolitic eruption. Although many of the specific premonitory events for such an eruption might resemble precursors to a smaller rhyolitic eruption, the magnitudes would be expected to be correspondingly greater, there might be geophysical activity over an areally large source, and the course of events would be expected to be more complex and of longer duration than for a smaller eruption.

\section{Hydrothermal-explosion hazards}

The potential hazards and probabilities of future hydrothermal-explosion events in Yellowstone National Park are considered in this section, based upon information summarized earlier about previous such events at Yellowstone and elsewhere. (Also see appendices 1 and 2).

\section{How often do they occur?}

For several reasons, it is difficult to estimate the frequency with which hydrothermal explosions occur at Yellowstone National Park. First, there is no clear demarcation between a forceful geyser eruption that ejects mud and rock fragments and a more energetic explosion that creates a new crater. Second, no comprehensive catalog of explosion events has been compiled heretofore. Table 4 lists the results of a literature review that uncovered 26 examples of hydrothermal explosions that have been described in the past 126 years. They refer to events in which a new feature was created or the size of an existing thermal feature was increased significantly by explosive excavation. There are many other examples of geysering where mud and rock were thrown from the vent, including an eruption near Wall Pool in the Upper Geyser Basin during the Summer of 2006, while this report was being prepared. However, the catalog in table 4 refers to events where the vent walls or conduit are shattered and fragments are dispersed outward. Nearly all of the explosions in table 4 occurred at thermal areas close to roads, where visitors are most frequent and the likelihood of observation of an actual explosion or of recent deposits is highest. It is likely that similar explosions are much more frequent than tabulated in table 4. A conservative estimate would be that at least one rock-hurling explosion occurs every two years at Yellowstone. Because these events are typically small and can occur any time of year, including when few visitors are present, the likelihood of harm to any individual park visitor is small. For 
example, while the annual probability of a small hydrothermal explosion within the park, assuming one eruption every two years, is 0.5 , if visitors are generally absent from geyser basins at night and between December and March, then the annual probability of an explosion that could cause personal injury falls to 0.5 x 0.67 (8 months/year) x 0.58 (14 hours/24-hour day), or 0.19 .

Moreover, explosions can occur away from trails and roads where people observe thermal features. When such factors are considered, the annual probability of an injury due to a small hydrothermal explosion falls to somewhere between 0.01 and 0.1 .

Larger events clearly represent a greater threat to park visitors and infrastructure. Muffler and others (1971) and Morgan and others (in review) identified geologic deposits formed through hydrothermal explosions within the past 14,000 years (table 3). Within the park, there are at least 18 such features, all with diameters greater than $300 \mathrm{~m}$. Two craters, Mary Bay and Turbid Lake, have diameters greater than $1500 \mathrm{~m}$.

One can generalize the probability of hydrothermal explosions by plotting explosion magnitude (crater size) versus frequency, simplified as annualized probability as shown in table 5.

In figure 31, these data plot as a straight line on a logarithmic plot of annualized probability versus the area of the newly formed crater (a proxy for eruption magnitude). Interpolation along this line implies that one could expect an explosion large enough to produce a crater $100 \mathrm{~m}$ in diameter every 200 years.

Such an analysis is consistent with the energetics of hydrothermal explosions. Browne and Lawless (2001) estimated that the energy releases of even large explosions, producing craters 1000 $\mathrm{m}$ across, represent only a few weeks to months of the heat flow from the system. Hedenquist and Henley (1985) produced a similar assessment for the prehistoric Waiotapu eruptions in New Zealand (craters ranging from 60 to $250 \mathrm{~m}$ in diameter). They concluded that the eruption that formed the present Champagne pool (now $70 \mathrm{~m}$ in diameter) released the energy equivalent of 30 hours of natural heat flux from that feature. Using such reasoning, Browne and Lawless (2001) advised that hydrothermal explosions should be relatively common events in long-lived geothermal areas and do not require unusual conditions.

\section{Potential effects}

As stated above, small hydrothermal eruptions creating craters a few meters across are unlikely to cause frequent injury to park visitors or damage to infrastructure. Larger explosions, however, are more energetic, and their effects could be correspondingly greater. We have estimated that an explosion creating a 100-m-diameter crater might occur in Yellowstone about once every 200 years. A series of similar-sized craters formed between one and two thousand years ago in the Waiotapu geothermal system of New Zealand. As described by Hedenquist and Henley (1985), deposits from these explosions extend 5 to 20 times greater than the diameters of their source craters; thus, rock fragments might fly as far as $2000 \mathrm{~m}$ from a $100-\mathrm{m}$ crater. Areas near the explosion source would be buried beneath thick fragmental deposits. At the Okaro crater in New Zealand, deposits are 2 or more meters thick within $400 \mathrm{~m}$ of the originally 250 -m-wide crater, and ejecta deposits extend up to $1000 \mathrm{~m}$ from the vent (Hedenquist and Henley, 1985). Morgan and others (in review) note that rock fragments were ejected at least as far as 3.5 to $4 \mathrm{~km}$ from the Mary Bay crater rim during its period of explosive activity, 13,600 years ago. Fragments from the Indian Pond explosion crater are found as far as $3 \mathrm{~km}$ from the vent (Morgan and others, 2003b).

Another potential hazard from hydrothermal explosions is the release of substantial amounts of toxic gases such as $\mathrm{H}_{2} \mathrm{~S}$ and $\mathrm{CO}_{2}$. The topic of toxic gas is discussed later in this hazard assessment, but it is worth pointing out here that gas released during hydrothermal explosions at Dieng, Indonesia, in 1979, killed 142 people. The gas was discharged from several adjacent areas that had first ejected rocks and mud, forming several craters, the largest of which was $90 \mathrm{~m}$ wide and $100 \mathrm{~m}$ deep. At Yellowstone, there is no evidence that any hydrothermal explosions have been 
accompanied by significant toxic-gas release. On the other hand, the Yellowstone caldera is a prolific source of $\mathrm{CO}_{2}$ (Werner and Brantley, 2003), and it remains possible that explosions from vapor-dominated regions, areas without a record of historic explosions, may release significant quantities of gas.

\section{Precursory signals}

Prior to 1989 (when it exploded), Porkchop Geyser exhibited a variety of characteristics that could be taken to indicate a potential explosion. Its behavior changed from that of an irregular geyser to a perpetual spouter (i.e., in constant geyser-like eruption), and the temperature of its deep feeding waters increased (Fournier and others, 1991). With the spring emitting a roar audible from $2 \mathrm{~km}$ away, few visitors in the vicinity would have failed to notice its presence. Today, as then, a geyser behaving in such a manner would be monitored closely by YVO staff and collaborators. Other hydrothermal features in Yellowstone have experienced explosions after first displaying similar signs of instability. After the $M=7.51959$ Hebgen Lake earthquake, park geologist George Marler inventoried hundreds of features with altered behavior. One such feature, across the Firehole River from Biscuit Basin, originated as a set of newly formed fractures emitting steam with apparent superheat, at $\sim 95^{\circ} \mathrm{C}$. A fumarole exploded from this site sometime in the early spring of 1963, forming a crater $2.7 \times 4.9 \mathrm{~m}$ in size (Marler and White, 1975) that was subsequently named Seismic Geyser. Currently, the feature is a non-erupting hot spring. Hydrothermal explosions following earthquakes would be fundamentally unpredictable.

The Dieng, Indonesia, hydrothermal explosion of February 20, 1979 was preceded for several days by shallow seismic swarms (Allard and others, 1989). During the three hours prior to the beginning of the explosions, three earthquakes were felt by nearby villagers $3 \mathrm{~km}$ distant from the explosion source. Once initiated, the explosive activity lasted for about 2 days. Other thermal features at Dieng, as elsewhere, have exploded without conspicuous precursory activity (Allard and others, 1989). White (1955) described an eruption at the Lake City Hot Springs northeastern California in March 1951 that dispersed 300,000 tons of mud, greatly modifying 20 acres of hotspring area and dispersing fine dust at distances more than $6 \mathrm{~km}$ from the center. The activity occurred without any warning to local residents and farmers. Hydrothermal explosions occur nearly every year from hot springs and geothermal wellheads in the Taupo Volcanic Zone of New Zealand. In particular, Rotorua, a developed geothermal area and tourist attraction, has produced scores of such eruptions over the past 100 years without obvious precursors (Scott and Cody, 2000; Browne and Lawless, 2001).

Clearly, some hydrothermal eruptions can initiate quickly, including but not limited to those triggered by earthquakes. Others seem to follow years of anomalous activity of hot springs and fumaroles. Because hydrothermal explosions typically appear to be shallow-rooted phenomena, initiating close to the surface, geophysical signals are most likely to affect localized areas within only a few hundred meters of the actual explosion site. At most volcanoes and hydrothermal systems, including Yellowstone, the station spacing of seismometers, tilt meters and other monitoring equipment will only rarely yield sufficient information to detect such precursory activity. Local monitoring networks with multiple sensors at a geyser basin might be sufficient to detect precursors such as ground tilting or subtle tremor, but as no such experiment has yet been undertaken, this supposition remains unproven.

\section{Where are hydrothermal explosions most likely to occur?}

Both historic (table 4 and fig. 25) and prehistoric (table 3 and fig. 24) hydrothermalexplosion craters are located predominantly in the Firehole River geyser basins, in and around Yellowstone Lake, and in the southern part of the Norris-Mammoth Corridor. The preponderance 
of historic explosion sites within the Firehole River and Norris basins may partly reflect greater visitation and scrutiny of thermal features in those areas but also is consistent with liquiddominated systems having near-surface temperatures near boiling being more likely to experience explosions than vapor-dominated areas that are not continuously saturated with liquid.

The north half of Yellowstone Lake and the adjacent area has long-been known as a site of large explosion craters and hosts an active liquid-dominated geothermal system (Muffler and others, 1971; Morgan and others, 1977; Otis and others, 1977; Wold and others, 1977; Morgan and others, 2003b). Besides the explosion craters listed in table 3, numerous small sublacustrine explosion craters have been identified within linear fissure zones by high-resolution imaging (Johnson and others, 2003; Morgan and others, 2003b; Morgan and others, in press-a). Johnson and others (2003) and Morgan and others (2003b) considered domal areas on the lake floor to be the most likely sites of future hydrothermal explosions. These areas are manifested by gently warped areas of the lake floor having at most 30 meters of apparent uplift (Morgan and others, in press-b). Hydrothermal alteration is inferred from the nature of seismic reflections; doming is interpreted to have occurred as a result of hydrothermal pressurization beneath a sealed zone of low permeability resulting from precipitation of siliceous sinter or silicification (Morgan and Shanks, 2005). Some of these domal areas are breached by vents, the formation of which would have relieved any notable overpressure. Domes without any evidence of breaching were considered by Johnson and others (2003) as the most likely to experience future explosive activity.

Figures 24 and 25 identify a significant number of historic and prehistoric explosion craters within the acid-sulfate terrains that overlie vapor-dominated systems. As such, one cannot negate the possibility that these areas too are susceptible to explosive activity and may present a significant hydrothermal-explosion hazard. It remains possible, however, that many of the observed hydrothermal-eruption craters in vapor-dominated areas, such as Roaring Mountain, Fern Lake, Hot Springs Basin, and Sulphur Hills, were formed at a time preceding present vapordominated activity. White and others (1971) noted that the Mud Volcano region showed evidence for having earlier been a liquid-dominated system. Many inactive sinter terraces were apparently encroached upon by acid-sulfate mineralization, indicating a local increase in the depth to the boiling ground water table and cessation of surface flow of silica-saturated waters. Fournier (1989) noted similar evidence of a previous liquid-dominated system that precipitated siliceous sinter at Hot Springs Basin, an area today characterized almost solely by acid-sulfate mineralization and without outflow of appreciable neutral-Cl waters (Allen and Day, 1935). Plausibly, the large explosion craters in these areas occurred prior to or during a transition from liquid- to vapordominated conditions.

Though Yellowstone's silica-depositing geyser basins and acid-sulfate thermal areas are all known to host hydrothermal-explosion features, the same cannot be said for calcium carbonate travertine deposits in areas such as Mammoth Hot Springs, Terrace Spring, and Calcite Springs. Typically, the waters issuing in these areas are $20-30^{\circ} \mathrm{C}$ below the local boiling temperature and, therefore, pose less threat of destabilization. No evidence for previous explosions has been found in these areas. The greatest hazards related to travertine-forming areas are buildup of toxic or unhealthy levels of $\mathrm{CO}_{2}$, as discussed later, and local subsidence of the ground surface due to formation of sinkholes in travertine areas. Unlike silica, the solubility of calcite increases with decreasing temperature, so that migration of cold ground water, especially when it is acidic, can create caves and sinkholes. Such features are common at Mammoth Hot Springs and pose a continual threat to park infrastructure.

In summary, two types of thermal areas at Yellowstone could potentially host future hydrothermal explosions. The geologic and historic records show that the thermal areas with active discharge of neutral, high-chloride waters, especially those hosting geysers, are most likely to experience explosions. Vapor-dominated regions covered with acid-sulfate soils may also 
experience explosions, though perhaps less regularly than areas with abundant shallow boiling ground water. Travertine-forming regions do not appear to experience hydrothermal explosions.

\section{Seasonal and long-term effects on hydrothermal explosions}

Fournier and others (1991) noted that the 1989 explosion of Porkchop Geyser corresponded with the onset of a seasonal disturbance common in the Norris Geyser Basin (summarized by White and others, 1988), typically occurring in late summer and characterized by increased heat discharge, increased boiling, and chemical changes. The disturbance is akin to an underground geyser eruption, where an increase in local heat and boiling migrates through the shallow subsurface (White and others, 1988; Fournier and others, 1991). White and others (1988) speculate that the disturbances are due to changes in the local ground water pressure, typically related to seasonal fluctuations. The temporal correlation of the Porkchop explosion and the basin-wide Norris disturbance suggests that hydrothermal explosions might be more likely during periods of increased heat discharge and seasonal or longer-term fluctuations in the pressure of the ground water table. The feedback between ground water pressure and earthquakes was recently discussed by L. B. Christiansen and others (2005), who noted seasonal variations in seismicity beneath Yellowstone Lake, increasing during periods of reduced lake levels. The observed drop in the level of Yellowstone Lake in late summer and early fall lowers the hydrostatic head on sublacustrine hydrothermal vents, apparently sufficient to cause increased release of $\mathrm{H}_{2} \mathrm{~S}$-rich gas bubbles and entrainment of fine-grained sediments in upwelling hydrothermal fluids (Morgan and Shanks, 2005).

The potential effects of longer-term variations in climate on stability of hydrothermal systems can be inferred from the data presented by Muffler and others (1971) and Bargar and Fournier (1988), showing fluid-inclusion filling temperatures in secondary inclusions that were higher than present-day hydrostatic boiling temperatures. After departure of glacial ice from the Yellowstone region, the hydrothermal system apparently remained at least temporarily superheated relative to the newly lowered hydrostatic pressure. Under such conditions, the Yellowstone hydrothermal systems might have been especially susceptible to explosion-triggering mechanisms such as earthquakes or drainage of glacial lakes. The established chronology of large hydrothermal-explosion craters is insufficient to show that large explosions were more common during the very latest Pleistocene, shortly following ice melting. Recent work (Pierce and others, 2002; Morgan and others, in review) suggests that most large hydrothermal explosions in Yellowstone occurred at times that preclude a direct link to deglaciation.

Future climate variability, even in the absence of glaciation, might be expected to affect the stability of hydrothermal reservoirs. Drops in the water level of Yellowstone Lake or reduction in the ground water table at the Norris or Firehole River Geyser Basins could increase the likelihood of explosive hydrothermal activity in those regions. Many vapor-dominated reservoirs display evidence for conversion from an earlier stage as a liquid-dominated system (White and others, 1971; Moore and others, 2000). This evolution may occur due to explosive venting, reduced recharge, or other potential mechanisms. As discussed above, the increase in boiling associated

with such a conversion could result in explosions. It is possible that long-term drought and associated reduced recharge could induce hydrothermal explosions in reservoirs in the process of converting from liquid-dominated to vapor-dominated conditions.

\section{Hazard mitigation}

Infrastructure: Hydrothermal explosions at Yellowstone occur solely in geothermal areas. Foremost among these areas are the geyser basins where silica-saturated, neutral, Cl-rich waters emerge at or close to their boiling point. The Upper and Lower Geyser Basins, Norris Geyser 
Basin, West Thumb Geyser Basin, and the area within and adjacent to the north half of Yellowstone Lake are the areas most likely to experience hydrothermal explosions. Park infrastructure should be minimized in these areas, and new construction would best be concentrated away from hydrothermal basins.

Documentation: Areas exhibiting superheat (water or fumarole temperatures above the local boiling point) should be monitored carefully by YVO and park staff. Subsequent to large, felt earthquakes, park staff should document changes to thermal features using a formal archival system that can be made widely available and accessible.

Monitoring: The hazard from small hydrothermal explosions is relatively low. Small events, usually producing craters less than two meters across, happen every few years and are only rarely witnessed. However, events forming craters over 50 to $100 \mathrm{~m}$ in diameter do occur on a societally relevant timescale and could appreciably impact park infrastructure and visitor safety. Observational monitoring can be augmented by limited geophysical monitoring of ground deformation and seismicity in selected geyser basins and around the northern half of Yellowstone Lake and, perhaps, repeated geochemical sampling of hydrothermal fluids. Existing seismic and GPS stations are placed so as to minimize the "noise" from thermal features and maximize the signal from deep earthquakes and magmatic processes. More local monitoring designed to "listen" to geyser basins would initially be useful as a tool to understand the dynamics of geothermal areas on monthly to annual timescales. It is quite possible that precursors to some hydrothermal explosions would become evident in such monitoring.

\section{Gas-emission hazards}

There has been no systematic study of the concentrations of $\mathrm{CO}_{2}$ and $\mathrm{H}_{2} \mathrm{~S}$ in the air at Yellowstone. Nevertheless, because human death or serious illness from toxic gases in the air is exceedingly rare at Yellowstone, it is clear that gas concentrations are rarely at levels that could cause severe illness. In general, the flat topography in most of Yellowstone's thermal areas and the light to moderate winds are sufficient to readily disperse hydrothermal gases. Reconnaissance efforts to record the abundances of $\mathrm{CO}_{2}$ and $\mathrm{H}_{2} \mathrm{~S}$ in thermal areas show that concentrations at waist level are rarely above $0.1 \%$ and 2 ppm respectively, even adjacent to fumaroles (Jacob Lowenstern and Henry Heasler, unpublished data). Much higher and even lethal concentrations occasionally can be found in cracks, holes, and locations within $10 \mathrm{~cm}$ of the ground surface; such air, however, generally is unlikely to be inhaled.

Though concentrations of toxic gases are generally low in Yellowstone, it is clear that they can build up in valleys, caves, and tunnels and during windless conditions. The impact of gas concentrations on humans living in the park was documented as early as 1883, when a woman was overcome by vapors in the basement of one of the homes in Mammoth Hot Springs. The woman's absence was quickly noticed, and she was rushed into fresh air (Whittlesey, 1995, p. 66). Caves and sinkholes near Mammoth Hot Springs are known to harbor relatively high concentrations of $\mathrm{CO}_{2}$, which bubbles out of the local hot-spring waters. Poison Spring, Poison Cave, and the Stygian Cave are all known as places where dead birds, insects, and small mammals have been found (Whittlesey, 1995, p. 68).

"Death Gulch," is a well-known source of $\mathrm{CO}_{2}$ in the northeast section of Yellowstone National Park, along a short tributary of Cache Creek, $3 \mathrm{~km}$ above its confluence with the Lamar River. Temperatures in this area are well below boiling, but springs yield copious bubbles of gas, predominantly $\mathrm{CO}_{2}, \mathrm{H}_{2} \mathrm{~S}$, and methane $\left(\mathrm{CH}_{4}\right)$ (Werner and Brantley, 2003). During his visit in 1888, USGS geologist Walter Weed found the remains of six bears, an elk, squirrels, hares and numerous butterflies and insects in the gulch (Weed, 1889). All were concluded to have died through asphyxiation where $\mathrm{CO}_{2}$ and $\mathrm{H}_{2} \mathrm{~S}$ had accumulated to toxic levels. One of the bears had not yet begun to decompose, and Weed concluded that the death had been very recent. Death 
Gulch was visited in 1897 by T. A. Jaggar, who found the carcasses of seven grizzly bears and one black bear (Traphagen, 1904). Traphagen visited Death Gulch in 1903 and recorded more than $10 \% \mathrm{CO}_{2}$ in air near the bottom of the gulch and verified that gas emitted from openings in the ground was mainly $\mathrm{CO}_{2}$ but contained over $10,000 \mathrm{ppm}_{2} \mathrm{~S}$. Flies placed into these openings died within six seconds (Traphagen, 1904).

Yellowstone's only documented human death by gas inhalation occurred in 1939 when workers were lowered in a bucket into a 26-foot-deep pit near the Yellowstone River at Tower Junction, dug to gather information about geological conditions relevant to nearby construction (Whittlesey, 1995, p. 67). In trying to rescue a fellow construction worker who was overcome by the vapors, another worker, Bill Nelson, lost consciousness and later died. Later tests revealed $\mathrm{H}_{2} \mathrm{~S}$ concentrations of 200 to $400 \mathrm{ppm}$ in the pit and $\mathrm{CO}_{2}$ levels of $20 \%$. The combination was sufficient to cause another rescuer to lose consciousness after only a few short breaths. After this incident, Bureau of Mines engineers also tested the air at Devils Kitchen at Mammoth Hot Springs. Their finding of $7 \% \mathrm{CO}_{2}$ spurred them to recommend closing of that and other nearby caves to visitation (Whittlesey, 1995). The caves have remained closed since then.

A more recent episode of toxic-gas inhalation occurred in March 2004, when five bison died along a section of the Gibbon River adjacent to the Norris Geyser Basin (Heasler and Jaworowski, 2004). The bison were all lying in similar positions, with their legs stiffly perpendicular to their bodies, and showed no signs of poor health prior to their deaths. Park biologists and geologists concluded that toxic gas inhalation was the most likely cause of death (Heasler and Jaworowski, 2004). Though the area is adjacent to thermal features rich in $\mathrm{CO}_{2}$ and $\mathrm{H}_{2} \mathrm{~S}$, dangerous concentrations of these gases were not found in ambient air at the time of discovery of the animals, or since then. Consideration of the previous month's weather records caused Heasler and Jaworowski (2004) to conclude that toxic levels of gas accumulated along the river bottom during a brief time of cold weather and associated atmospheric inversion about one week before the animals were found. It remains unknown whether a spike in outgassing from the hydrothermal system may have contributed to the probable gas accumulation.

\section{Relevant examples of toxic volcanic or hydrothermal gas hazards}

As noted above, Yellowstone differs from most volcanoes in having very low emissions of acid gases such as $\mathrm{SO}_{2}$ and $\mathrm{HCl}$. A notorious hazard at some volcanic systems is buildup of $\mathrm{CO}_{2}$ in deep volcanic lakes, which can result in catastrophic degassing of the deep waters. Such events happened twice in Cameroon from Lakes Monoun and Nyos in 1984 and 1986, respectively. The latter event occurred when a landslide into the lake caused dissolved $\mathrm{CO}_{2}$ to be released rapidly from solution, causing a cloud of $\mathrm{CO}_{2}$ to flow downhill from the crater lake and killing 1700 people and even more livestock (Sigurdsson, 1988). Following these events, engineers constructed vertical pipes in the lakes to ensure continual degassing of the deep gas-charged waters. The Cameroon Lakes are meromictic, meaning they are stratified into different layers that do not normally mix, a consequence of the geometry of the lakes (deep and of small diameter), the temperate climate, and the fact that $\mathrm{CO}_{2}$-rich water is denser than the fresh water above. Yellowstone Lake and the other lakes of Yellowstone National Park are dimictic; their deep and shallow waters mix twice per year, in the spring and fall (Thompson and others, 1998).

Additionally, hot springs on the floor of Yellowstone Lake tend to increase the temperatures of bottom waters, enabling mixing as the warm waters rise. Because of the continual mixing, it is highly unlikely that dissolved $\mathrm{CO}_{2}$ concentrations in the deep waters of Yellowstone lakes could increase to levels sufficient to cause catastrophic degassing.

Though $\mathrm{CO}_{2}$ is unlikely to be released suddenly due to lacustrine processes, it remains possible that dangerous amounts of this gas could be released by an explosion from the hydrothermal system. A precedent for such an event occurred in the Dieng Plateau, a volcanic area 
in Indonesia known for accumulations of $\mathrm{CO}_{2}$ in depressions and hollows, as well as for frequent eruptions of mud from volcanic craters. In 1979, 134 people were killed while attempting to escape from the area following several days of earthquakes, hydrothermal explosions, and an accompanying mud flow that blocked access to the village (Allard and others, 1989). Another death by $\mathrm{CO}_{2}$ poisoning at Dieng occurred in March 1992 (Global Volcanism Network, 1992).

Several deaths have been attributed to $\mathrm{CO}_{2}$ poisoning at Mammoth Mountain, a ski resort in a volcanic region of eastern California. Carbon dioxide discharge was observed there in the early 1990s and resulted in several tree-kills that covered 70 hectares. High concentrations of $\mathrm{CO}_{2}$ have been measured there in depressions in the snow around trees and adjacent to buildings (Sorey and others, 1996). In 1998, a skier is believed to have died as a result of $\mathrm{CO}_{2}$ poisoning after falling into a snow well adjacent to a U.S. Forest Service restroom (Hill, 2000). In March 2006, three additional gas-related deaths occurred at Mammoth Mountain as members of the Mammoth Mountain ski patrol made repairs to fencing that surrounds a near-boiling fumarole high on the mountain (Becerra, 2006). Although the area is normally roped off during the winter because the fumarole melts a hole in the snow - a hazard for skiers - a heavy snowfall partially obscured the fence. During repairs, two individuals fell into the hole and quickly succumbed to the $\mathrm{CO}_{2}$ gas. Another team member died during a subsequent rescue attempt. The tragedy was clearly engendered by the unusually thick snow pack, but the ultimate hazard was the fumarole itself and its $\mathrm{CO}_{2}$ emissions.

\section{Hazard mitigation}

Given the prodigious $\mathrm{CO}_{2}$ and $\mathrm{H}_{2} \mathrm{~S}$ emissions at Yellowstone, the former estimated at 45,000 tons per day (Werner and Brantley, 2003), it is clear that toxic gases pose a potential hazard to park visitors. Normally, the gases dissipate quickly into the atmosphere, and only rarely are visitors present where gas concentrations can cause harm. Nevertheless, incidents such as those at Dieng and Mammoth Mountain are possible at Yellowstone. Also, unless safety measures are utilized, incidents similar to the one that caused a worker's death at Tower Junction could occur again. It is important that National Park staff working in suspect areas be made aware of the hazards from toxic gases, carry appropriate equipment to detect anomalous gas concentrations, and follow recommended protocols. Caves near thermal areas should continue to be closed to visitors, including park staff. As is park policy, visitors in thermal areas should stay on maintained pathways and away from thermal features and enclosed areas where dense gases can accumulate.

Because so few data on gas concentrations in thermal areas have been collected, we recommend further reconnaissance studies, including continuous monitoring to assess the effects of wind, air temperature, and other climatic factors on gas concentrations in and around specific thermal areas. These types of studies would aid in determining whether occasional gas surges from thermal features produce high concentrations of toxic gas in the surrounding air and what hazard such events might pose to park staff and visitors. Monitoring of buildings, particularly basements, might also be justified in areas of possible toxic-gas accumulation.

\section{Conclusions}

Yellowstone National Park is the site of a large, active, and integrated tectonic, magmatic, and hydrothermal system. Potential hazards related to possible future activity of this system, as evaluated in this report, vary greatly among the various possible types of future activity.

Earthquake hazards, although they are among the most commonly recurring hazards, are not evaluated explicitly in this preliminary open-file version of the assessment. Their assessment, however, is planned for a forthcoming, more complete version. Of the remaining hazards discussed here, the most likely to occur are hydrothermal explosions, with an average annual probability from 
as high as 0.5 (equivalent to an average recurrence of 2 years) for small explosions to perhaps $5 \times 10^{3}$ (an average recurrence of 200 years) for explosions large enough to form a 100-m-diameter crater. Hydrothermal explosions that might result in potential risks to people have a probability no greater than 0.1 per year (an average recurrence of 10 years) for small explosions.

Potential for a volcanic eruption is much lower than that for hydrothermal explosions. Probabilities range from about $6 \times 10^{-5}$ per year (an average recurrence of 16,000 years) for a basaltic eruption in the region to about $5 \times 10^{-5}$ (average recurrence of 20,000 years) for a large rhyolitic lava eruption within the Yellowstone caldera or $2 \times 10^{-5}$ per year (average recurrence of 50,000 years) for a small extracaldera rhyolitic eruption. The probability of a large caldera-forming eruption is very much smaller than any of these but is not readily quantifiable; it probably is less than $10^{-6}$. The aggregate annual probability of any volcanic eruption occurring from the Yellowstone magmatic system is $\sim 1 \times 10^{-4}$, an average recurrence of 10,000 years.

Continued monitoring by YVO is likely to enable recognition of premonitory indications before any volcanic eruption. There are likely to be few if any indications of an impending hydrothermal explosion although certain conditions, such as major earthquakes or seasonal or longterm lowering of local water tables, tend to favor the occurrence of hydrothermal explosions. The YVO monitoring system should at least provide rapid information about any such event once it occurs. Toxic gas releases, especially of $\mathrm{CO}_{2}$ or $\mathrm{H}_{2} \mathrm{~S}$, would probably be recognized only after they occur, mainly by indirect evidence such as dead or distressed plants or animals.

Advance preparation for responses to potential hazards from future volcanic eruptions or hydrothermal explosions can help mitigate their effects on Yellowstone National Park and its staff and visitors. Despite the low probability of a future volcanic eruption at Yellowstone, the hazardous consequences possible from even a small eruption render important the preparation of plans for appropriate responses to any such future event.

\section{Acknowledgments}

We appreciate the help of Jeff Cross and Ralph Taylor, both members of the Geyser Observation and Study Association (GOSA), who provided documentation of some of the historic hydrothermal explosions at Yellowstone. Nicole Nastanski and Terry Spell of the University of Nevada, Las Vegas and John Obradovich provided unpublished ${ }^{40} \mathrm{Ar} /{ }^{39} \mathrm{Ar}$ age data for Yellowstone volcanic rocks. Andy Calvert provided unpublished ${ }^{40} \mathrm{Ar} /{ }^{39} \mathrm{Ar}$ dates of Yellowstone rhyolites and advised us more broadly on issues related to geochronology. Tom Olliff and John Varley of Yellowstone National Park were supportive of this effort and helpful throughout its planning and

preparation. Kathryn Flynn assembled much of the geographic, monitoring and scientific data used to construct the figures. Shaul Hurwitz, Bill Evans, Pat Shanks, and Deborah Bergfeld of the USGS reviewed portions of this report relevant to hydrothermal and gas hazards. Wes Hildreth and Dave Hill provided detailed technical reviews of the entire document.

\section{References Cited}

Allard, P., Dajlevic, D., and Delarue, C., 1989, Origin of carbon dioxide emanation from the 1979 Dieng eruption, Indonesia: Implications for the origin of the 1986 Nyos catastrophe: Journal of Volcanology and Geothermal Research, v. 39, p. 195-206.

Allen, E. T., and Day, A. L., 1935, Hot springs of the Yellowstone National Park: Washington, D.C., Carnegie Institution of Washington Publication 466, 525 p.

Anders, M. H., Geissman, J. W., Piety, L. A., and Sullivan, J. T., 1989, Parabolic distribution of circumeastern Snake River Plain seismicity and latest Quaternary faulting: Migratory pattern and association with the Yellowstone hotspot: Journal of Geophysical Research, v. 94, p. 1589-1621. 
Bacon, C. R., 1983, Eruptive history of Mount Mazama and Crater Lake caldera, Cascade Range, U.S.A.: Journal of Volcanology and Geothermal Research, v. 18, p. 57-115.

Bargar, K. E., and Fournier, R. O., 1988, Effects of glacial ice on subsurface temperatures of hydrothermal systems in Yellowstone National Park, Wyoming: Fluid-inclusion evidence: Geology, v. 16, p. 1077-1080.

Baxter, P. J., 2005, Human impacts of volcanoes, in Marti, J., and Ernst, G. G. J., eds., Volcanoes and the Environment: Cambridge, Cambridge University Press, p. 273-303.

Bebbington, M. S., and Lai, C. D., 1996, On nonhomogeneous models for volcanic eruptions: Mathematical Geology, v. 28, p. 585-600.

Becerra, H., 2006, Ski resort cited in toxic fume deaths, Los Angeles Times, October 7, 2006.

Benz, H. M., and Smith, R. B., 1984, Simultaneous inversion for lateral velocity variations and hypocenters in the Yellowstone region using earthquake and refraction data: Journal of Geophysical Research, v. 89, p. 1208-1220.

Bindeman, I. N., Valley, J. W., Wooden, J. L., and Persing, H. M., 2001, Post-caldera volcanism: In situ measurement of $\mathrm{U}-\mathrm{Pb}$ age and oxygen isotope ratio in Pleistocene zircons from Yellowstone caldera: Earth and Planetary Science Letters, v. 189, no. 197-206.

Browne, P. R. L., and Lawless, J. V., 2001, Characteristics of hydrothermal eruptions, with examples from New Zealand and elsewhere: Earth-Science Reviews, v. 52, p. 299-331.

Bryan, T. S., 1995, The Geysers of Yellowstone, Third Edition: Boulder, Colo., University Press of Colorado., $472 \mathrm{p}$.

Camp, V. E., and Ross, M. E., 2004, Mantle dynamics and genesis of mafic magmatism in the intermontane Pacific Northwest: Journal of Geophysical Research, v. 109, no. B08204, p. doi:10.1029/2003JB002838.

Christiansen, L. B., Hurwitz, S., Saar, M. O., Ingebritsen, S. E., and Hsieh, P. A., 2005, Seasonal seismicity at western United States volcanic centers: Earth and Planetary Science Letters, v. 240, p. 307-321.

Christiansen, R. L., 1979, Cooling units and composite sheets in relation to caldera structure, in Chapin, C. E., and Elston, W. E., eds., Ash-flow Tuffs: Geological Society America Special Paper 180, p. 29-42.

— 1982, Late Cenozoic volcanism of the Island Park area, eastern Idaho, in Bonnichsen, B., and Breckenridge, R. M., eds., Cenozoic geology of Idaho: Idaho Bureau of Mines and Geology Bulletin 26, p. 345-368.

1984, Yellowstone magmatic evolution: Its bearing on understanding large-volume explosive volcanism, in Explosive volcanism: Inception, Evolution, and Hazards: Washington, D.C., National Academy of Sciences, p. 84-95. 2001, The Quaternary and Pliocene Yellowstone Plateau volcanic field of Wyoming, Idaho, and Montana: U.S. Geological Survey Professional Paper 729-G, 144 p. http://pubs.usgs.gov/pp/pp729g/.

Christiansen, R. L., and Blank, H. R., Jr., 1972, Volcanic stratigraphy of the Quaternary rhyolite plateau in Yellowstone National Park: U.S. Geological Survey Professional Paper 729-B, 18 p.

1974, Geologic map of the Madison Junction quadrangle, Yellowstone National Park, Wyoming: U.S. Geological Survey Geologic Quadrangle Map GQ-1190, scale 1:62,500.

Christiansen, R. L., Foulger, G. R., and Evans, J. R., 2002, Upper-mantle origin of the Yellowstone hotspot: Geological Society of America Bulletin, v. 114, p. 1245-1256.

Cox, D. R., and Lewis, P. A. W., 1966, The statistical analysis of series of events: London, Methuen, $285 \mathrm{p}$. 
Crone, A. J., 1987, Surface faulting associated with the 1983 Borah Peak earthquake at Doublespring Pass Road, east-central Idaho: Geological Society of America Abstracts with Programs, v. 20, no. 7, p. 13.

Davis, C. C., 1930, New pool near Shoshone snowshoe cabin: Yellowstone Nature Notes, v. 4, no. 4, July 1930.

Dewey, J. W., 1983, Instrumental seismicity of central Idaho: Seismological Society of America Bulletin, v. 77, p. 819-836.

Doser, D. I., 1985, Source parameters and faulting processes of the 1959 Hebgen Lake, Montana, earthquake sequence: Journal of Geophysical Research, v. 90, p. 4537-4555.

Doser, D. I., and Smith, R. B., 1983, Seismicity of the Teton-Southern Yellowstone Region, Wyoming: Seismological Society of America Bulletin, v. 73, p. 1369-1394. , 1989, An assessment of source parameters of earthquakes in the Cordillera of the western United States: Seismological Society of America Bulletin, v. 79, p. 1383-1409.

Dzurisin, D., Savage, J. C., and Fournier, R. O., 1990, Recent crustal subsidence at Yellowstone caldera, Wyoming: Bulletin of Volcanology, v. 52, p. 247-270.

Dzurisin, D., and Yamashita, K. M., 1987, Vertical surface displacements at Yellowstone caldera, Wyoming: Journal of Geophysical Research, v. 92, no. B13, p. 13,753-713,766.

Dzurisin, D., Yamashita, K. M., and Kleinman, J. W., 1994, Mechanisms of crustal uplift and subsidence at the Yellowstone caldera, Wyoming: Bulletin of Volcanology, v. 56, p. 261270.

Farrell, J., 2007, The time-spatial seismicity and development of a GIS database for the Yellowstone region: Salt Lake City, University of Utah, M.S. thesis, 70 p.

Fournier, R. O., 1989, Geochemistry and dynamics of the Yellowstone National Park hydrothermal system: Annual Reviews of Earth and Planetary Sciences, v. 17, p. 13-53.

Fournier, R. O., Thompson, J. M., Cunningham, C. G., and Hutchinson, R. A., 1991, Conditions leading to a recent small hydrothermal explosion at Yellowstone National Park: Geological Society of America Bulletin, v. 103, p. 1114-1120.

Gansecki, C. A., Mahood, G. A., and McWilliams, M. O., 1996, 40Ar/39Ar geochronology of rhyolites erupted following collapse of the Yellowstone caldera, Yellowstone Plateau volcanic field: Implications for crustal contamination: Earth and Planetary Science Letters, v. 42, no. 91-107.

Global Volcanism Network, 1992, Sudden gas emission kills one person and hospitalizes two others: Bulletin of the Global Volcanism Network, April 1992, v. 17, no. 4, http://www.volcano.si.edu/world/volcano.cfm?vnum $=0603-20=$.

Handal, S., and Barrios, L. A., 2004, Hydrothermal eruptions in El Salvador: A review, in Rose, W. I., Bommer, J. J., Lopez, D. L., Carr, M. J., and Major, J. J., eds., Natural Hazards in El Salvador: Geological Society of America Special Paper 375, p. 245-255.

Heasler, H., and Jaworowski, C., 2004, Geologic overview of a bison-carcass site at Norris Geyser Basin, March 2004: Yellowstone National Park Geology Report, 7 p., http://www.nps.gov/yell/naturescience/upload/norrisbison.pdf.

Hedenquist, J. W., and Henley, R. W., 1985, Hydrothermal eruptions in the Waiotapu geothermal system, New Zealand: Their origin, associated breccias and relation to precious metal mineralization: Economic Geology, v. 80, p. 1640-1668.

Hildreth, W., Christiansen, R. L., and O'Neil, J. R., 1984, Oxygen isotopic study of the Yellowstone Plateau volcanic field: Journal of Geophysical Research, v. 89, p. 8339-8369.

Hildreth, W., Halliday, A. N., and Christiansen, R. L., 1991, Isotopic and chemical evidence concerning the genesis and contamination of basaltic and rhyolitic magma beneath the Yellowstone Plateau volcanic field: Journal of Petrology, v. 32, p. 63-138. 
Hill, P. M., 2000, Possible asphyxiation from carbon dioxide of a cross-country skier in eastern California: A deadly volcanic hazard: Wilderness and Environmental Medicine, v. 11, p. 192-195.

Hobart, J. R., 1989, A Norris explosion crater update: Geyser Observation and Study Association Transactions, v. 1, p. 209-210.

Husen, S., and Smith, R. B., 2004, Probabilistic earthquake relocation for the Yellowstone National Park Region, Wyoming: Seismological Society of America Bulletin, v. 94, no. 3, p. 880896.

Husen, S., Smith, R. B., and Waite, G. P., 2004, Evidence for gas and magmatic sources beneath the Yellowstone volcanic field from seismic tomographic imaging: Journal of Volcanology and Geothermal Research, v. 131, p. 397-410.

Hutchinson, R. A., 1985, Hydrothermal changes in the Upper Geyser Basin, Yellowstone National Park, after the 1983 Borah Peak, Idaho, earthquake, in Stein, R. S., and Bucknam, R. C., eds., Proceedings of Workshop XXVIII on the Borah Peak, Idaho, earthquake: U.S. Geological Survey Open-file Report OF85-290, p. 612-624.

$\ldots, 1987$, New thermal feature develops near Norris Geyser Basin: Yellowstone Park Memorandum N3039(YELL), 2 p.

_ 1990, Thermal and seismic highlights of Yellowstone, 1986-87: Yellowstone National Park Archives, Box N-211, Folder 14.

Izett, G. A., 1981, Volcanic ash beds: Recorders of upper Cenozoic silicic pyroclastic volcanism in the Western United States: Journal of Geophysical Research, v. 86, no. B11, p. 1020010222.

Izett, G. A., and Wilcox, R. E., 1982, Map showing localities and inferred distributions of the Huckleberry Ridge, Mesa Falls, and Lava Creek ash beds (Pearlette family ash beds) of Pliocene and Pleistocene age in the Western United States and Southern Canada: U. S. Geological Survey Miscellaneous Investigations Series Map I-1325, 1:4,000,000.

Johnson, S. Y., Stephenson, W. J., Morgan, L. A., Shanks, W. C., III, and Pierce, K. L., 2003, Hydrothermal and tectonic activity in northern Yellowstone Lake: Geological Society of America Bulletin, v. 115, p. 954-871.

Keith, T. E. C., and Muffler, L. J. P., 1978, Minerals produced during cooling and hydrothermal alteration of ash-flow tuff from Yellowstone drill hole Y-5: Journal of Volcanology and Geothermal Research, v. 3, p. 373-402.

Klein, F. W., 1982, Patterns of historical eruptions at Hawaiian volcanoes: Journal of Volcanology and Geothermal Research, v. 12, p. 1-35.

Lanphere, M. A., Champion, D. E., Christiansen, R. L., Izett, G. A., and Obradovich, J. D., 2002, Revised ages for tuffs of the Yellowstone Plateau volcanic field: Assignment of the Huckleberry Ridge Tuff to a new geomagnetic polarity event: Geological Society of America Bulletin, v. 114, p. 559-568.

Locke, W. W., and Meyer, G. A., 1994, A 12,000-year record of vertical deformation across the Yellowstone caldera margin: The shorelines of Yellowstone Lake: Journal of Geophysical Research, v. 99, no. B10, p. 20,079-020,094.

Lowenstern, J. B., Christiansen, R. L., Smith, R. B., Morgan, L. A., and Heasler, H., 2005, Steam explosions, earthquakes, and volcanic eruptions--What's in Yellowstone's future?: U.S. Geological Survey Fact Sheet 2005-3024, 6 p., http://pubs.usgs.gov/fs/2005/3024/.

MacLeod, N. S., Walker, G. W., and McKee, E. H., 1976, Geothermal significance of eastward increase in age of upper Cenozoic rhyolitic domes in southeastern Oregon, Second United Nations Symposium on Development and Use of Geothermal Resources, Proceedings: Washington, D.C., p. 465-474. 
Mandavi, S., 2005, Toxicity, Hydrogen Sulfide, http://www.emedicine.com/EMERG/topic258.htm, updated 20 December 2005.

Marler, G. D., 1964, Effects of the Hebgen Lake earthquake of August 17, 1959, on the hot springs of the Firehole Geyser basins, Yellowstone National Park: U.S. Geological Survey Professional Paper 435-Q, p. 185-197.

— 1973 , Inventory of thermal features of the Firehole River Geyser Basins, Yellowstone National Park: Washington, D.C., National Technical Information Service Report PB $221289,648 \mathrm{p}$.

Marler, G. D., and White, D. E., 1975, Seismic Geyser and its bearing on the origin and evolution of geysers and hot springs of Yellowstone National Park: Geological Society of America Bulletin, v. 86, p. 749-759.

Meertens, C. M., and Smith, R. B., 1991, Crustal deformation of the Yellowstone caldera from first GPS measurements: 1987-1989: Geophysical Research Letters, v. 18, p. 1763-1766.

Meyer, G. A., and Locke, W. W., 1986, Origin and deformation of Holocene shoreline terraces, Yellowstone Lake, Wyoming: Geology, v. 14, p. 699-702.

Milby, T. H., and Baselt, R. C., 1999, Hydrogen sulfide poisoning: clarification of some controversial issues: American Journal of Industrial Medicine, v. 35, no. 2, p. 192-195.

Miller, D. S., and Smith, R. B., 1999, $P$ and $S$ velocity structure of the Yellowstone volcanic field from local earthquake and controlled-source tomography: Journal of Geophysical Research, v. 104 , no. B7, p. $15,105-115,121$.

Moore, J. N., Adams, M. C., and Anderson, A. J., 2000, The fluid inclusion and mineralogic record of the transition from liquid- to vapor-dominated conditions in The Geysers geothermal system, California: Economic Geology, v. 95, no. 8, p. 1719-1737.

Morgan, L. A., and Shanks, W. C., 2005, Influences of rhyolitic lava flows on hydrothermal processes in Yellowstone Lake and on the Yellowstone Plateau, in Inskeep, W. P., and McDermott, T. R., eds., Geothermal biology and geochemistry in Yellowstone National Park: Bozeman, Mont., Montana State University Thermal Biology Institute, p. 31-52.

Morgan, L. A., Shanks, W. C., III, Lovalvo, D., Pierce, K. L., Lee, G., Webring, M., Stephenson, W. J., Johnson, S. Y., Finn, C., Schulze, B., and Harlan, S. S., 2003a, The floor of Yellowstone Lake is anything but quiet!: Yellowstone Science, v. 11, no. 2, p. 14-30.

Morgan, L. A., Shanks, W. C., Lee, G. A., and Webring, M., in press-b, Bathymetry, geology, and selected perspective views of the floor of Yellowstone Lake: U.S. Geological Survey Scientific Investigations Map.

Morgan, L. A., Shanks, W. C., Lovalvo, D., Lee, G., Pierce, K. L., Webring, M., Stephenson, W. J., Johnson, S. Y., Finn, C., and Harlan, S. S., in press-a, The floor of Yellowstone Lake is anything but quiet: New discoveries from high-resolution sonar imaging, seismic reflection profiling, and submersible studies, in Morgan, L. A., ed., Integrated geoscience studies in the Greater Yellowstone Geoecosystem: U.S. Geological Survey Professional Paper 1717.

Morgan, L. A., Shanks, W. C., and Pierce, K. L., in review, Hydrothermal processes above a large magma chamber: Large hydrothermal systems and explosions in Yellowstone National Park.

Morgan, L. A., Shanks, W. C. I., Lovalvo, D. A., Johnson, S. Y., Stephenson, W. J., Pierce, K. L., Harlan, S. S., Finn, C. A., Lee, G., Webring, M., Schulze, B., Duhn, J., Sweeney, R., and Balistrieri, L., 2003b, Exploration and discovery in Yellowstone Lake: Results from highresolution sonar imaging, seismic reflection profiling and submersible studies: Journal of Volcanology and Geothermal Research, v. 122, p. 221-242.

Morgan, P., Blackwell, D. D., Spafford, R. E., and Smith, R. B., 1977, Heat flow measurements in Yellowstone Lake and the thermal structure of the Yellowstone caldera: Journal of Geophysical Research, v. 82, p. 3719-3732. 
Muffler, L. J. P., White, D. E., and Truesdell, A. H., 1971, Hydrothermal explosion craters in Yellowstone National Park: Geological Society of America Bulletin, v. 82, p. 723-740.

Muir, J., 1888, Picturesque California and the Region West of the Rocky Mountains, from Alaska to Mexico: J. Dewing Publishing Co., 486 p.

Mullineaux, D. R., 1974, Pumice and other pyroclastic deposits in Mount Rainier National Park, Washington: U. S. Geological Survey Bulletin 1326, 83 p. , 1996, Pre-1980 tephra-fall deposits erupted from Mount St. Helens, Washington: U.S. Geological Survey Professional Paper 1563, 99 p.

Murphy, L. M., and Brazee, R. J., 1964, Seismological investigations of the Hebgen Lake earthquake, in The Hebgen Lake, Montana, earthquake of August 17, 1959: U.S. Geological Survey Professional Paper 435-C, p. 13-17.

Nathenson, M., 2001, Probabilities of volcanic eruptions and application to the recent history of Medicine Lake volcano, in Vecchia, A. V., ed., A unified approach to probabilistic risk assessments for earthquakes, floods, landslides, and volcanoes, November 16-17, 1999, Golden, Colo.: U.S. Geological Survey Open-file Report 01-324, p. 71-71.

Newhall, C. G., and Dzurisin, D., 1988, Historical unrest at large calderas of the world: U. S. Geological Survey Bulletin 1855, 1108 p.

Obradovich, J. D., 1992, Geochronology of the late Cenozoic volcanism of Yellowstone National Park and adjoining areas, Wyoming an Idaho: U.S. Geological Survey Open-file Report 92408, $45 \mathrm{p}$.

Otis, R. M., Smith, R. B., and Wold, R. J., 1977, Surveys of Yellowstone Lake, Wyoming: Journal of Geophysical Research, v. 82, p. 3705-3717.

Paperiello, R., 1998, The explosive history of Wall Pool and Black Opal Pool in Biscuit Basin: Geyser Observation and Study Association Transactions, v. 6, p. 106-114.

Pelton, J. R., and Smith, R. B., 1979, Recent crustal uplift in Yellowstone National Park: Science, v. 206, p. 1179-1182.

, 1982, Contemporary vertical surface displacements in Yellowstone National Park: Journal of Geophysical Research, v. 87, p. 2745-2761.

Pierce, K. L., Adams, K. D., and Sturchio, N. C., eds., 1991, Geologic setting of the Corwin springs Known Geothermal Resources Area-Mammoth Hot Springs area in and adjacent to Yellowstone National Park: Menlo Park, Calif., U.S. Geological Survey Water-Resources Investigations Report 91-4052, C1-C37 p.

Pierce, K. L., Cannon, K. P., Meyer, G. A., Trebesch, M. J., and Watts, R. D., 2002, Post-glacial inflation-deflation cycles, tilting, and faulting in the Yellowstone caldera based on Yellowstone Lake shorelines: U.S. Geological Survey Open-file Report 02-0142, 63 p., http://pubs.usgs.gov/of/2002/ofr-02-0142/.

Pierce, K. L., and Morgan, L. A., 1992, The track of the Yellowstone hotspot: Volcanism, faulting, and uplift, in Link, P. K., Kuntz, M. A., and Platt, L. B., eds., Regional Geology of eastern Idaho and western Wyoming: Geological Society of America Memoir 179, p. 1-53.

Pierce, K. L., Morgan, L. A., and Saltus, R. W., 2000, Yellowstone plume head: Postulated tectonic relations to the Vancouver slab, continental boundaries, and climate: U.S. Geological Survey Open-file Report 00498, 39 p., http://pubs.usgs.gov/of/2000/ofr-00-0498/.

Pitt, A. M., Weaver, C. S., and Spence, W., 1979, The Yellowstone Park earthquake of June 30, 1975: Seismological Society of America Bulletin, v. 69, p. 187-205.

Puskas, C., Smith, R. B., Meertens, C. M., and Chang, W. L., 2007, Crustal deformation of the Yellowstone-Snake River Plain Volcanic System: Campaign and continuous GPS observations, 1987-2004: Journal of Geophysical Research, v. 112, no. B03401, doi:10.1029/2006JB004325. 
Puskas, C. M., Smith, R. P., and Meertens, C. M., 2002, GPS-derived models of intraplate deformation of the Yellowstone hotspot: American Geophysical Union Transactions (Eos), v. 83, no. 47 (Fall Meeting Supplement), Abstract S11A-1104.

Rampino, M. R., 1991, Volcanism, climatic change, and the geologic record, in Fisher, R. V., and Smith, G. A., eds., Sedimentation in volcanic settings: Tulsa, Okla., Society for Sedimentary Geology (SEPM), p. 9-18.

Rampino, M. R., and Ambrose, S. H., 2000, Volcanic winter in the Garden of Eden: The Toba supereruption and the late Pleistocene human population crash, in McCoy, F. W., and Heiken, G., eds., Volcanic hazards and disasters in human antiquity: Boulder, Colo., Geological Society of America Special Paper 345, p. 71-82.

Rampino, M. R., Self, S., and Strothers, R. B., 1988, Volcanic winters: Annual Reviews of Earth and Planetary Sciences, v. 16, p. 73-99.

Richins, W. D., Pechmann, J. C., Smith, R. B., Langer, C. J., Goter, S. K., Zollweg, J. E., and King, J. J., 1987, 1983 Borah Peak, Idaho, earthquake and its aftershocks: Seismological Society of America Bulletin, v. 77, p. 694-723.

Scott, B. J., and Cody, A. D., 2000, Response of the Rotorua geothermal system to exploitation and varying management regimes: Geothermics, v. 29, p. 573-592.

Scott, W. E., Iverson, R. M., Vallance, J. W., and Hildreth, W., 1995, Volcano hazards in the Mount Adams region, Washington: U.S. Geological Survey Open-File Report 95-492, 11 p.

Shanks, W. C., Alt, J. C., and Morgan, L. A., in review, Geochemistry of sublacustrine hydrothermal deposits in Yellowstone Lake: Hydrothermal reactions, stable isotope systematics, sinter deposition, and spire growth, in Morgan, L. A., ed., Integrated geoscience studies in the Greater Yellowstone Geoecosystem: U.S. Geological Survey Professional Paper 1717.

Shanks, W. C., Morgan, L. A., Balistrieri, L., and Alt, J. C., 2005, Hydrothermal vent fluids, siliceous hydrothermal deposits, and hydrothermally altered sediments in Yellowstone Lake, in Inskeep, W. P., and McDermott, T. R., eds., Geothermal biology and geochemistry in Yellowstone National Park: Bozeman, Mont., Montana State University Thermal Biology Institute, p. 53-72.

Sigurdsson, H., 1988, Gas bursts from Cameroon crater lakes: A new natural hazard: Disasters, v. 12, p. 131-146.

Simmons, S. F., Keywood, M., Scott, B. J., and Keam, R. F., 1993, Irreversible change of the Rotomahana-Waimangu hydrothermal system (New Zealand) as a consequence of a volcanic eruption: Geology, v. 21, p. 643-646.

Smith, E., and Bennett, K., 2006, Panther Creek volcano: Yellowstone Science, v. 14, no. 1, Winter 2006, p. 5-12.

Smith, R. B., and Arabasz, W. J., 1991, Seismicity of the Intermountain Seismic Belt, in Slemmons, D. B., Engdahl, E. R., Zoback, M. D., and Blackwell, D. D., eds., Neotectonics of North America: Boulder, Colo., Geological Society of America Decade Map Volume 1, p. 185-228.

Smith, R. B., and Braile, L. W., 1993, Topographic signature, space-time evolution, and physical properties of the Yellowstone-Snake River Plain volcanic system: The Yellowstone hotspot, in Snoke, A. W., Steidtmann, J., and Roberts, S. M., eds., Geology of Wyoming: Laramie, Wyo., Geological Survey of Wyoming Memoir 5, p. 694-754.

, 1994, The Yellowstone hotspot: Journal of Volcanology and Geothermal Research, v. 61, p. 121-187.

Smith, R. B., Richins, W. D., and Doser, D. I., 1985, The 1983 Borah Peak, Idaho, earthquake: Regional seismicity, kinematics of faulting, and tectonic mechanism, in Stein, R. S., and 
Bucknam, R. C., eds., Proceedings of Workshop XXVIII on the Borah Peak, Idaho, earthquake: U.S. Geological Survey Open-file Report OF85-0290, p. 236-263.

Smith, R. B., and Sbar, M. L., 1974, Contemporary tectonics and seismicity of the Western United States, with emphasis on the Intermountain Seismic Belt: Geological Society of America Bulletin, v. 85, p. 1205-1218.

Smith, R. B., Shuey, R. T., Pelton, J. R., and Bailey, J. P., 1977, Yellowstone Hot Spot, crustal properties from new earthquake and magnetic data: Journal of Geophysical Research, v. 82, p. 3665-3676.

Sorey, M. L., Farrar, C. D., and Evans, W. C., 1996, Invisible $\mathrm{CO}_{2}$ gas killing trees at Mammoth Mountain, California: U.S. Geological Survey Fact Sheet 172-96, 2 p.

Spell, T. L., Smith, E. I., Nastanski, N. M., and Bennett, K., 2004, Establishment and evolution of a new silicic magma system north of Yellowstone caldera: Geochronology, geochemistry, and petrographic relationships of extracaldera basalts and rhyolites in the Norris-Mammoth corridor: American Geophysical Union Transactions (Eos), v. 85, no. 47, Fall meeting supplement, abstract V52B-08.

Symonds, R. B., Gerlach, T. M., and Reed, M. H., 2001, Magmatic gas scrubbing: Implications for volcano monitoring: Journal of Volcanology and Geothermal Research, v. 108, no. 1-4, p. 303-341.

Tauxe, L., Luskin, C., Selkin, P., Gans, P., and Calvert, A., 2004, Paleomagnetic results from the Snake River Plain: Contribution to the time-averaged field global database: Geochemistry, Geophysics, and Geosystems, v. 5, no. 8, Q08H13, doi:10.1029/2003GC000661.

Taylor, R. C., and Grigg, J. B., 1999, Potts Hot Spring Basin Survey 1997-1998, unpublished manuscript: Geyser Observation and Study Association Press, 370 p.

Thompson, R. S., Hostetler, S. W., Bartlein, P. J., and Anderson, K. H., 1998, A strategy for assessing potential future changes in climate, hydrology, and vegetation in the Western United States: U. S. Geological Survey Circular 1153, 20 p.

Traphagen, F. W., 1904, Death Gulch: Science, v. 19 (new series), no. 485, p. 632-634.

Trimble, A. B., and Smith, R. B., 1975, Seismicity and contemporary tectonics of the Hebgen Lake-Yellowstone Park region: Journal of Geophysical Research, v. 80, p. 733-741.

U.S. Geological Survey, 1964, The Hebgen Lake, Montana, earthquake of August 17, 1959: U.S. Geological Survey Professional Paper 435, 242 p.

Vazquez, J. A., and Reid, M. R., 2002, Time scales of magma storage and differentiation of voluminous high-silica rhyolites at Yellowstone caldera, Wyoming: Contributions to Mineralogy and Petrology, v. 144, p. 274-285.

Waite, G. P., Smith, R. B., and Allen, R. L., 2006, Vp and Vs structure of the Yellowstone hot spot from teleseismic tomography: Evidence for an upper mantle plume: Journal of Geophysical Research, v. 111, no. B04303, doi:10.1029/2005JB003867.

Waite, G. P., and Smith, R. B., 2002, Seismic evidence for fluid migration accompanying subsidence of the Yellowstone caldera: Journal of Geophysical Research, v. 107, no. B9, 2177, doi:10.1029/2001JB000586.

$\ldots, 2004$, Seismotectonics and stress field of the Yellowstone volcanic plateau from earthquake first-motions and other indicators: Journal of Geophysical Research, v. 109, no. B02301, doi:10.1029/2003JB002675.

Watson, B. N., 1961, Effects of the August 17, 1959 earthquake and subsequent quaking upon the thermal features of Yellowstone National Park: Tucson, Ariz., University of Arizona, M.S. thesis, $83 \mathrm{p}$.

Weed, W. H., 1889, A deadly gas-spring in the Yellowstone Park: Science, v. 13, no. 315, p. 130132. 
Werner, C., and Brantley, S., 2003, $\mathrm{CO}_{2}$ emissions from the Yellowstone volcanic system: Geochemistry, Geophysics, and Geosystems, v. 4, no. doi:10.1029/2002GC000473, p. 27.

White, B. J. P., 2006, Seismicity, seismotectonics and preliminary earthquake hazard analysis of the Teton region, Wyoming: Salt Lake City, University of Utah, M. S. thesis, 279 p.

White, D. E., 1955, Violent mud-volcano eruption of Lake City hot springs, northeastern California: Geological Society of America Bulletin, v. 66, no. 9, p. 1109-1130.

White, D. E., Fournier, R. O., Muffler, L. J. P., and Truesdell, A. H., 1975, Physical results of research drilling in thermal areas of Yellowstone National Park, Wyoming: U.S. Geological Survey Professional Paper 892, 70 p.

White, D. E., Hutchinson, R. A., and Keith, T. E. C., 1988, The geology and remarkable thermal activity of Norris Geyser Basin, Yellowstone National Park, Wyoming: U.S. Geological Survey Professional Paper 1456, 84 p.

White, D. E., Muffler, L. J. P., and Truesdell, A. H., 1971, Vapor-dominated hydrothermal systems compared with hot-water systems: Economic Geology, v. 66, p. 75-97.

Whittlesey, L., 1988, Yellowstone Place Names: Helena, Montana, Montana Historical Society, $178 \mathrm{p}$.

— 1990, Monarch of all these mighty wonders: Tourists and Yellowstone's Excelsior Geyser, 1881-1890: Montana, The Magazine of Western History, v. 4, no. 2, p. 2-15. , 1995, Death in Yellowstone: Lanham, Md., Roberts Rinehart Publishers, 276 p.

Wicks, C., Jr., Thatcher, W., and Dzurisin, D., 1998, Migration of fluids beneath Yellowstone caldera inferred from satellite radar interferometry: Science, v. 282, p. 458-462.

Wicks, C. W., Thatcher, W., Dzurisin, D., and Svarc, J., 2006, Uplift, thermal unrest, and magma intrusion at Yellowstone caldera, observed with InSAR: Nature, v. 440, p. 72-75.

Wilson, C. J. N., and Hildreth, W., 1997, The Bishop Tuff: New insights from eruptive stratigraphy: Journal of Geology, v. 105, p. 407-439.

Wold, R. J., Mayhew, M. A., and Smith, R. B., 1977, Bathymetric and geophysical evidence for a hydrothermal explosion crater in Mary Bay, Yellowstone Lake, Wyoming: Journal of Geophysical Research, v. 82, p. 3733-3738.

Yellowstone Volcano Observatory, 2006, Volcano and earthquake monitoring plan for the Yellowstone Volcano Observatory, 2006-2015, U.S. Geological Survey Scientific Investigations Report 2006-5276, 13 p., http://pubs.usgs.gov/sir/2006/5276/. 


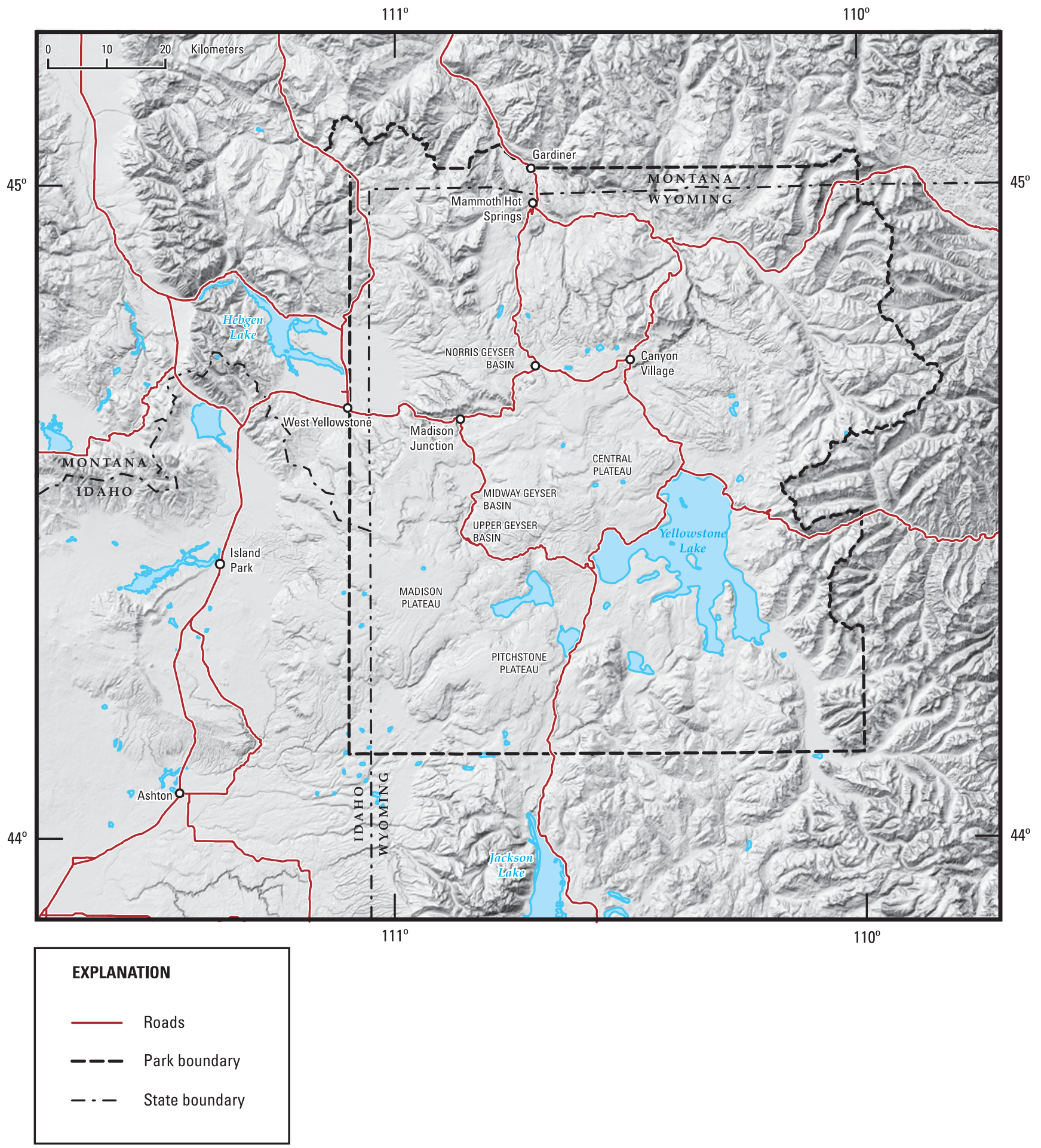

Figure 1. Map of Yellowstone National Park and vicinity showing the area considered in this report, its physiography, major roads (red lines), and selected place names. 


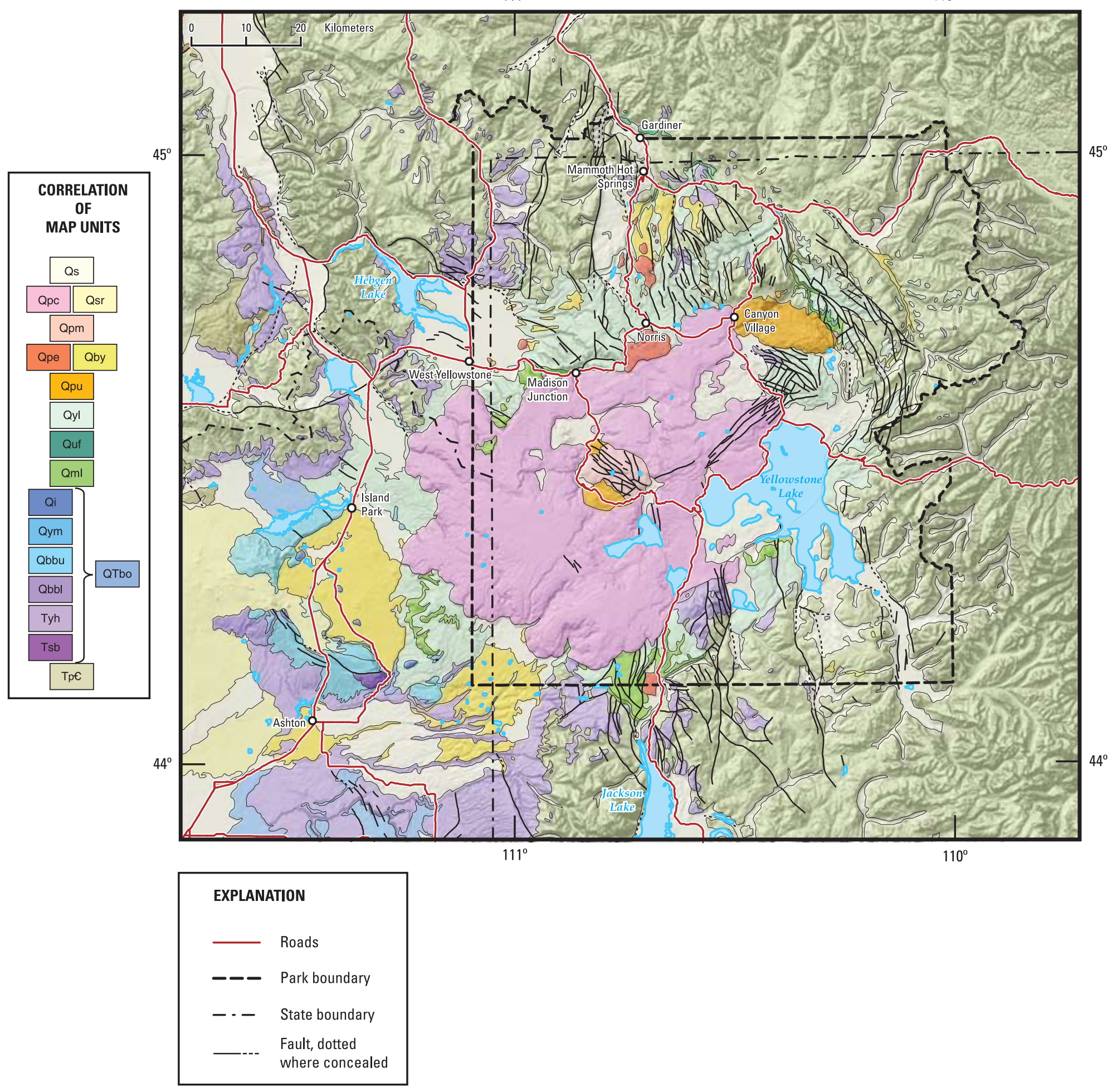

Figure 2. Geologic map of Yellowstone National Park and vicinity showing units associated with the Yellowstone Plateau volcanic field. Unit symbols: Os, surficial deposits; Opc, Plateau Rhyolite, Central Plateau Member; Osr, basalts of Snake River Group; Opm, Plateau Rhyolite, Mallard Lake Member; Ope, extracaldera rhyolites; Oby, young extracaldera basalts; Opu, Plateau Rhyolite, Upper Basin Member; Oyl, Lava Creek Tuff; Ouf, Undine Falls Basalt; Oml, Mount Jackson and Lewis Canyon Rhyolites; Qi, Island Park Rhyolite; Oym, Mesa Falls Tuff; Obbu, upper lavas of Big Ridge Rhyolite; Qbbl, lower lavas of Big Bend Ridge Rhyolite; Tyh, Huckleberry Ridge Tuff; Tsb, rhyolite of Snake River Butte; QTbo, older basalts; Tp€, rocks predating the Yellowstone Plateau volcanic field. After Christiansen (2001). 


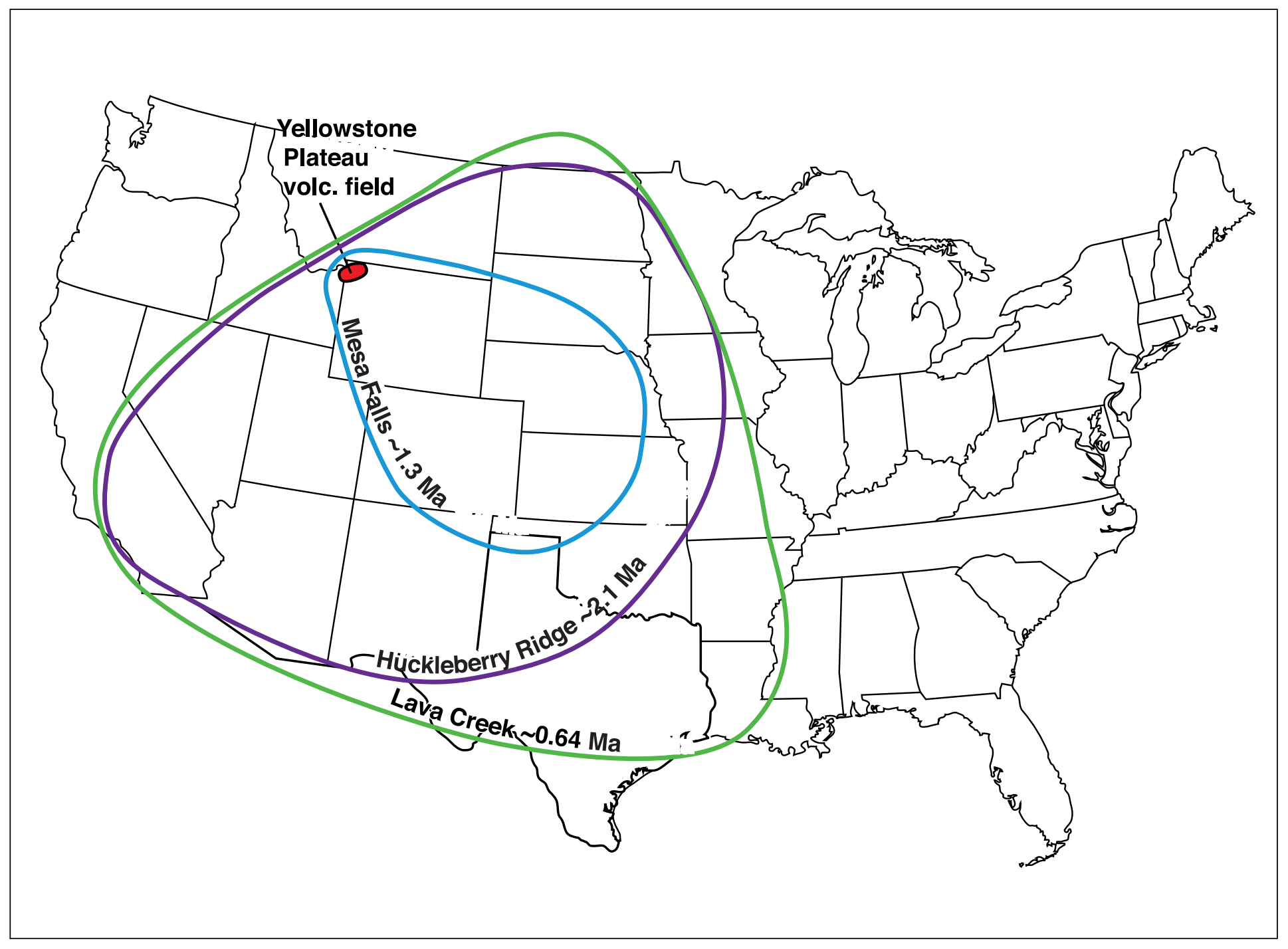

Figure 3. Map of the United States showing inferred distribution of airborne ash deposits erupted in the three major caldera-forming eruptive episodes of the Yellowstone Plateau volcanic field. Symbols: purple line, recognized extent of Huckleberry Ridge ash bed ( 2.1 Ma); blue line, recognized extent of Mesa Falls ash bed $(\sim 1.3 \mathrm{Ma})$; green line, recognized extent of Lava Creek ash bed ( 0.64 Ma). After Izett and Wilcox (1982). 


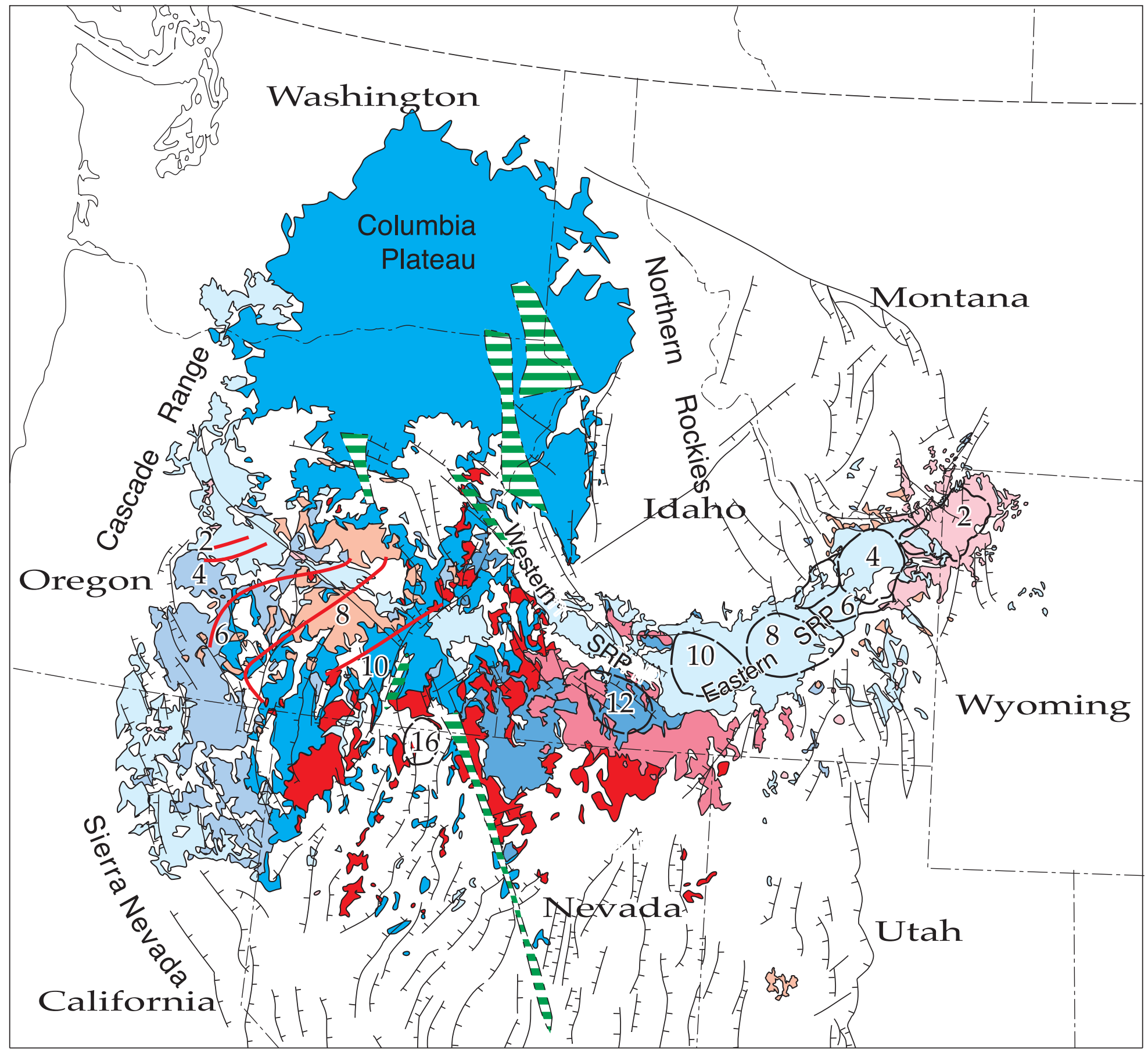

Figure 4. Map of the Northwestern United States showing major tectonic and volcanic features of $17 \mathrm{Ma}$ and younger. Rhyolites shown in shades of red; basalts shown in shades of blue; lighter shades for younger ages. Major rhyolitic centers of the Eastern Snake River Plain (covered by basalts) indicated by their ages of initiation $(\sim 12,10,8,6,4$, and $2 \mathrm{Ma})$ and approximate locations of calderas, after Pierce and Morgan (1992). Partly contemporaneous trend of oppositely propagating rhyolitic centers in eastern Oregon shown by age contours, after MacLeod and others (1976). Green-and-white-striped bands, vent zones for 17- to 14-Ma basalts of the Columbia River Group. Hachured lines, basin-range faults. Map after Christiansen and others (2002) 


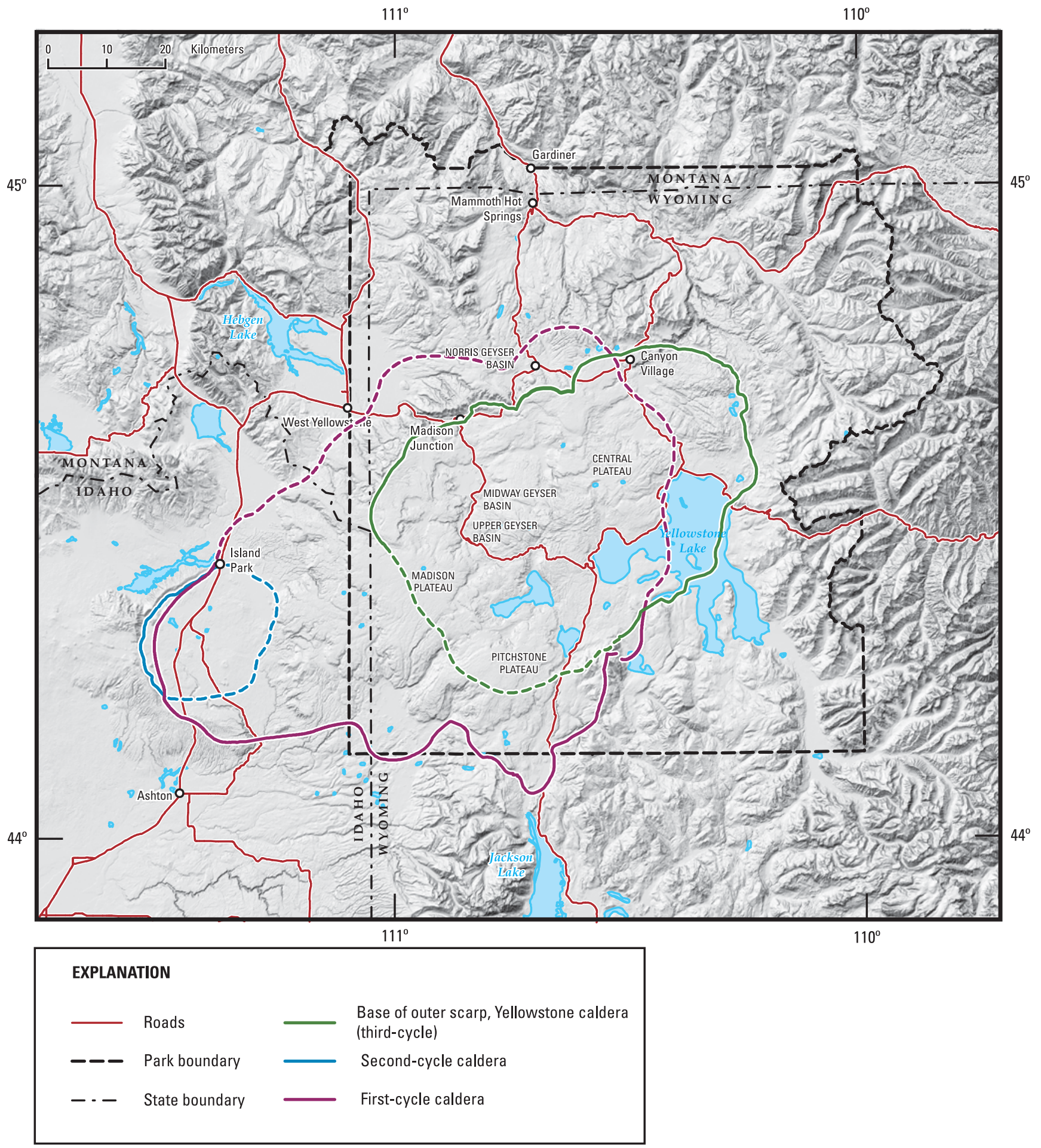

Figure 5. Map of Yellowstone National Park and vicinity showing structural caldera outlines (dashed where inferred) for each of the three large caldera-forming cycles of rhyolitic volcanism (after Christiansen, 2001) and locations of the major geyser basins. 


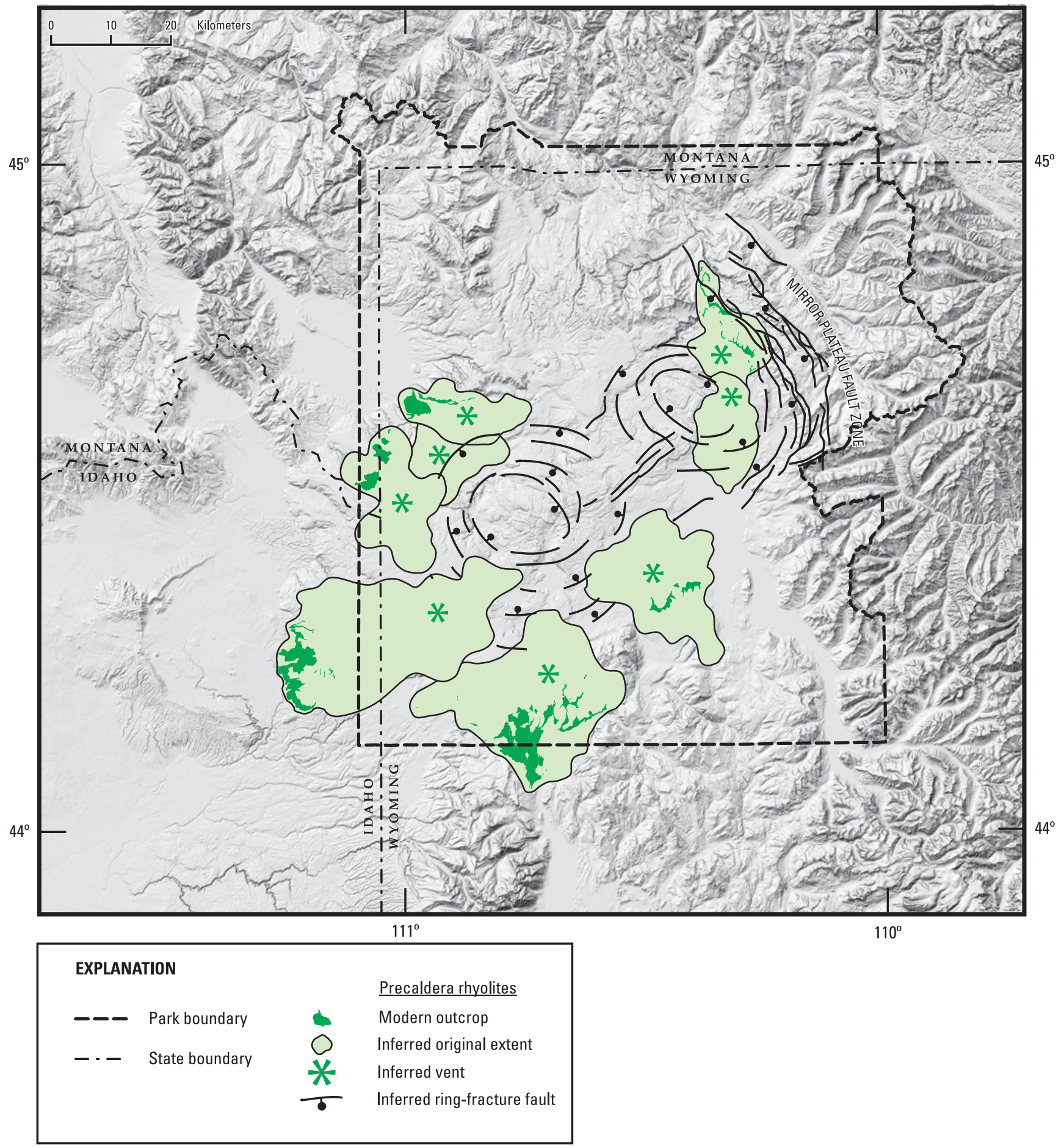

Figure 6. Map of Yellowstone National Park and vicinity showing precaldera third-cycle rhyolitic lava flows and inferred incipient ring-fracture zone of the Yellowstone caldera system. The Mirror Plateau fault zone is a tectonic fault zone that is influenced by the Yellowstone Plateau magmatic system and that functions as part of the Yellowstone caldera ring-fracture system. After Christiansen (2001). 


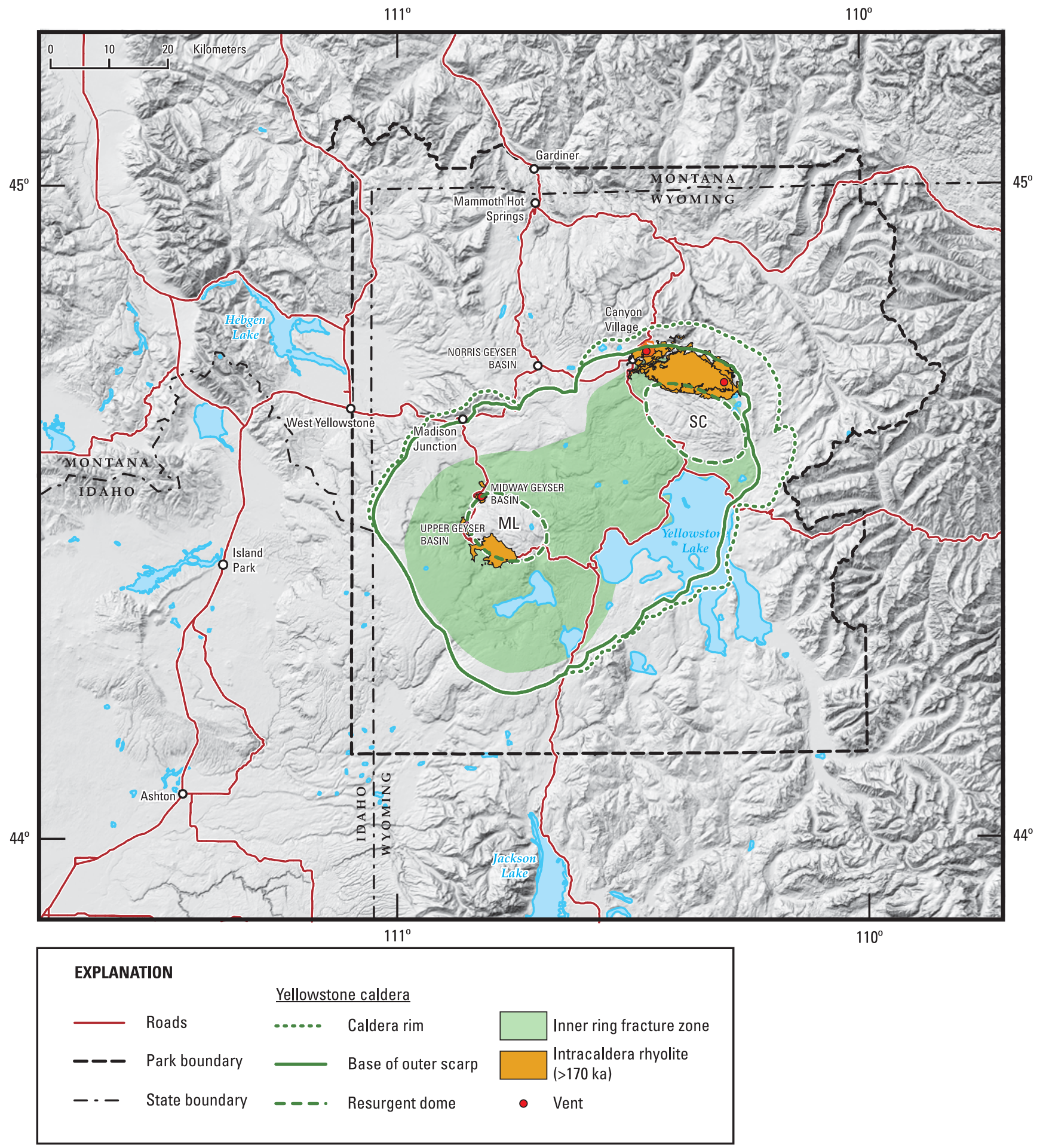

Figure 7. Map of Yellowstone National Park and vicinity showing the Yellowstone caldera rim, resurgent domes, and early postcaldera rhyolitic lavas. The inferred ring-fracture zone, along which the caldera subsided with eruption of the Lava Creek Tuff, lies between the resurgent domes and the base of the outer ring-fracture scarp. ML, Mallard Lake resurgent dome; SC, Sour Creek resurgent dome. ML, Mallard Lake resurgent dome; SC, Sour Creek resurgent dome. After Christiansen (2001). 


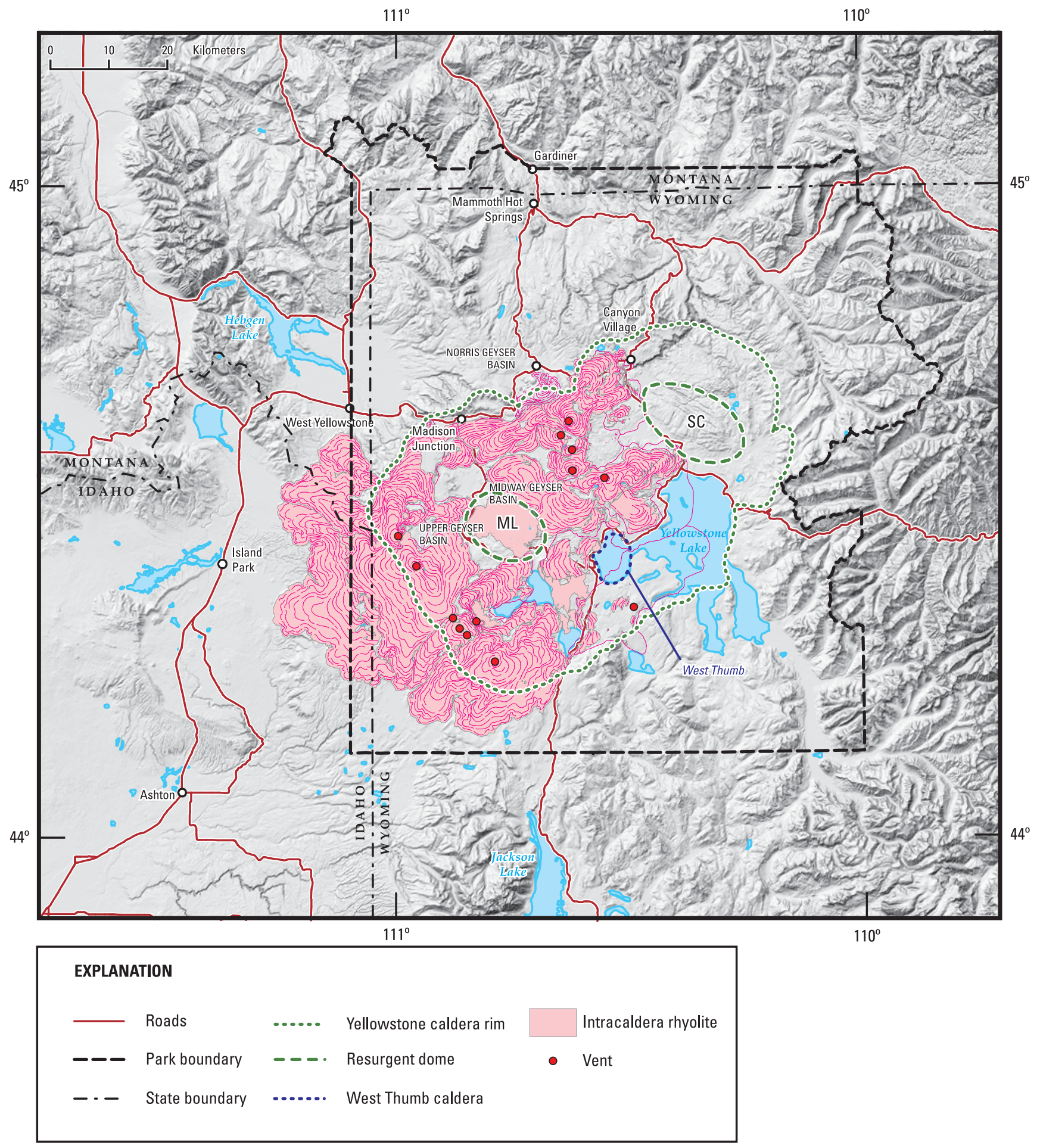

Figure 8. Map of Yellowstone National Park and vicinity showing the Yellowstone caldera, resurgent domes, and late postcaldera rhyolitic lavas. Vents for the lava flows form two linear zones across the caldera along the northwest-trending axes of the Pitchstone-Madison and Central Plateaus, respectively. ML, Mallard Lake resurgent dome; SC, Sour Creek resurgent dome. After Christiansen (2001); flow boundaries in Yellowstone Lake modified from Morgan and others (in press-b). 


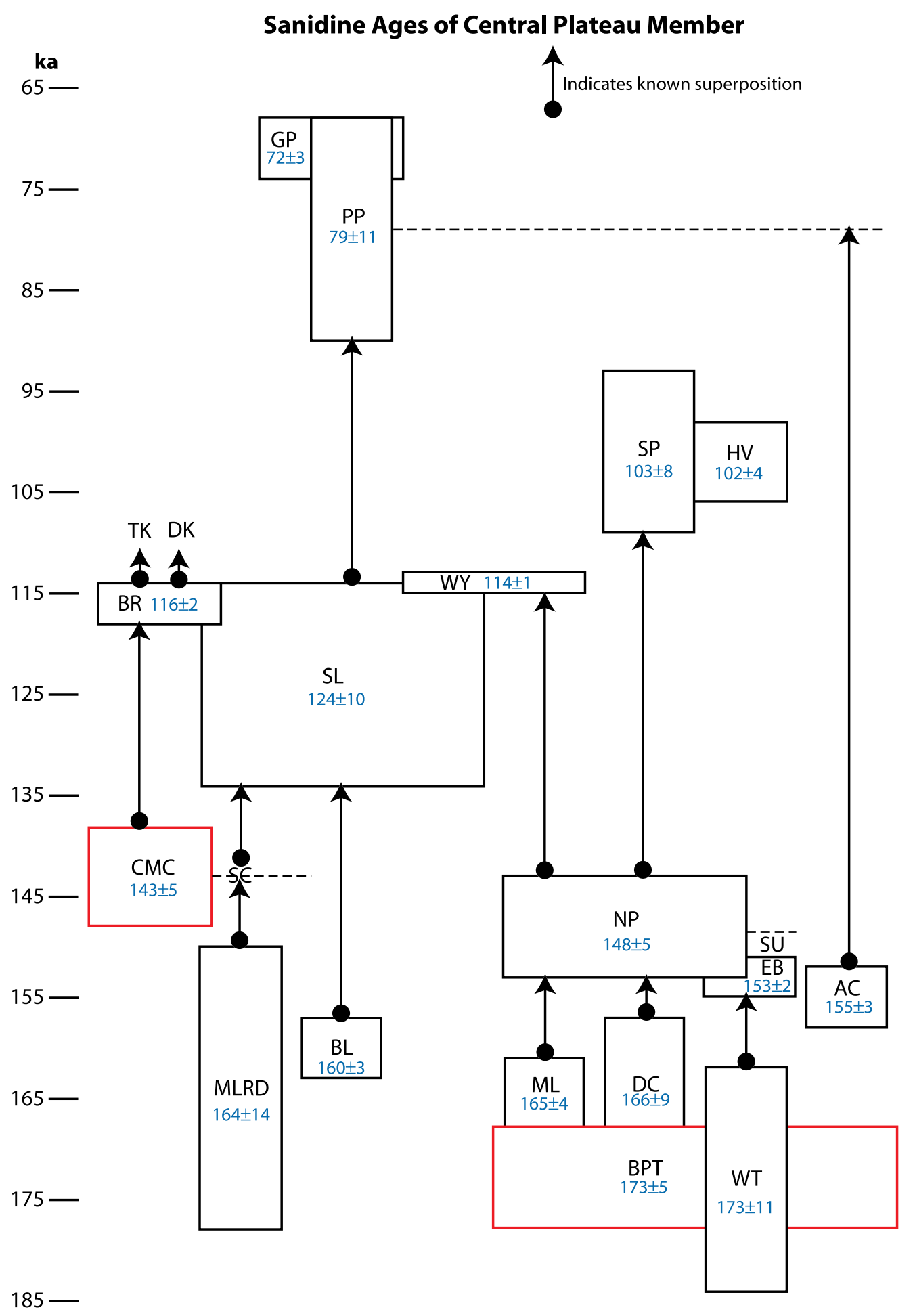

Figure 9. Sanidine ages of late intracaldera flows of the Yellowstone caldera. Ages, shown in blue, are in units of ka (thousand years ago), from table 1. Each box is centered at the nominal age and has vertical dimensions indicating the standard deviation of the presumed "best" age. Superpositions from field relations are indicated either by arrows or by the overlapping of boxes. Horizontal dashed lines extending to the right from three of the boxes indicate continuity of stratigraphic levels between parts of the diagram. Symbols: PP, Pitchstone Plateau flow; GP, Grants Pass flow; SP, Solfatara Plateau flow; HV, Hayden Valley flow; WY, West Yellowstone flow; TK, Trischman Knob dome; DK, Douglas Knob dome; BR, Bechler River flow; SL, Summit Lake flow; CMC, Tuff of Cold Mountain Creek; SC, Spring Creek flow; NP, Nez Perce Creek flow; SU, Spruce Creek flow; EB, Elephant Back flow; AC, Aster Creek flow; BL, Buffalo Lake flow; ML, Mary Lake flow; WT, West Thumb flow; BPT, Tuff of Bluff Point; DC, Dry Creek flow; MLRD, Mallard Lake flow. 


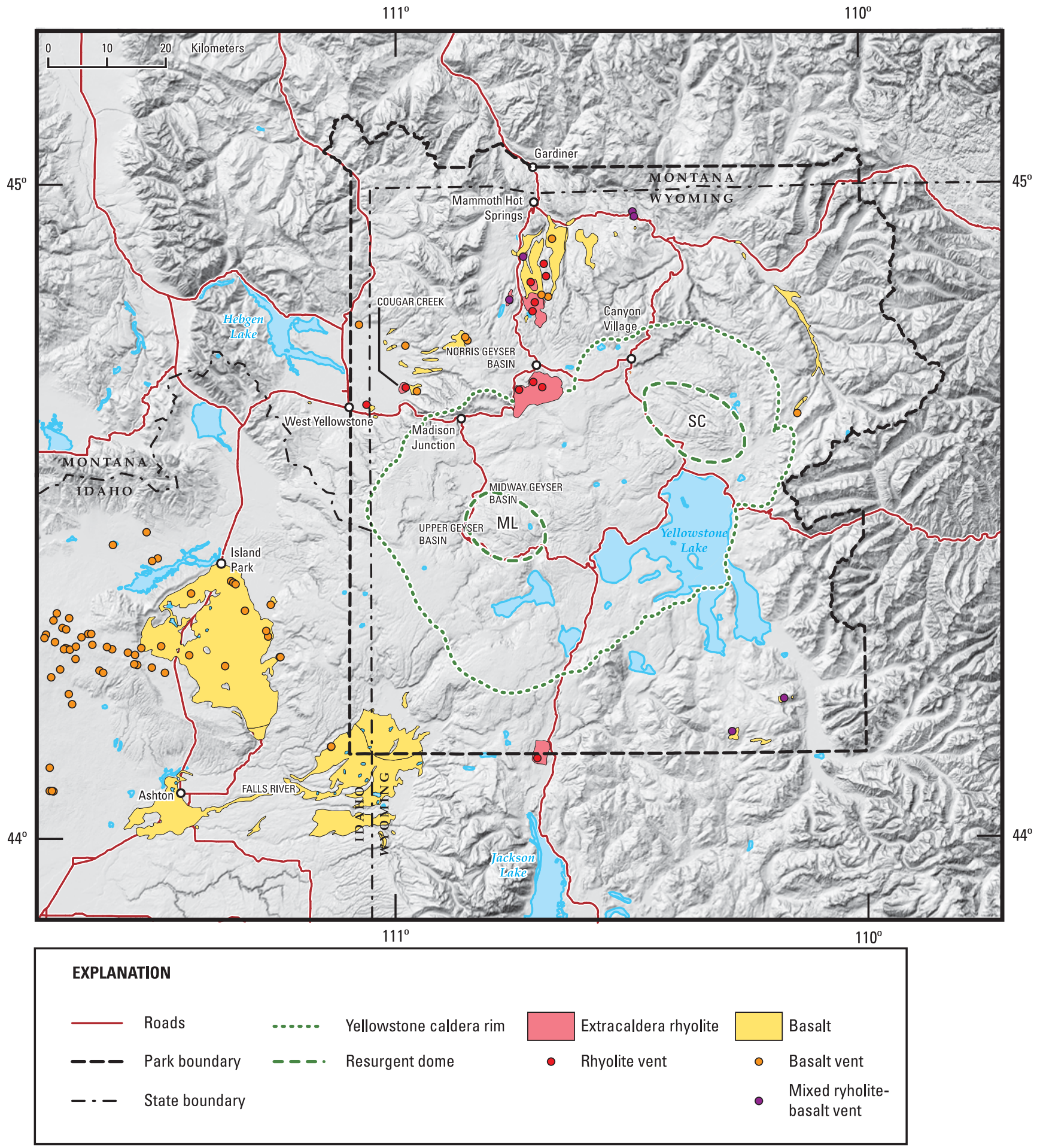

Figure 10. Map of Yellowstone National Park and vicinity showing extracaldera rhyolitic and basaltic lavas that postdate the Yellowstone caldera. ML, Mallard Lake resurgent dome; SC, Sour Creek resurgent dome. After Christiansen (2001). 


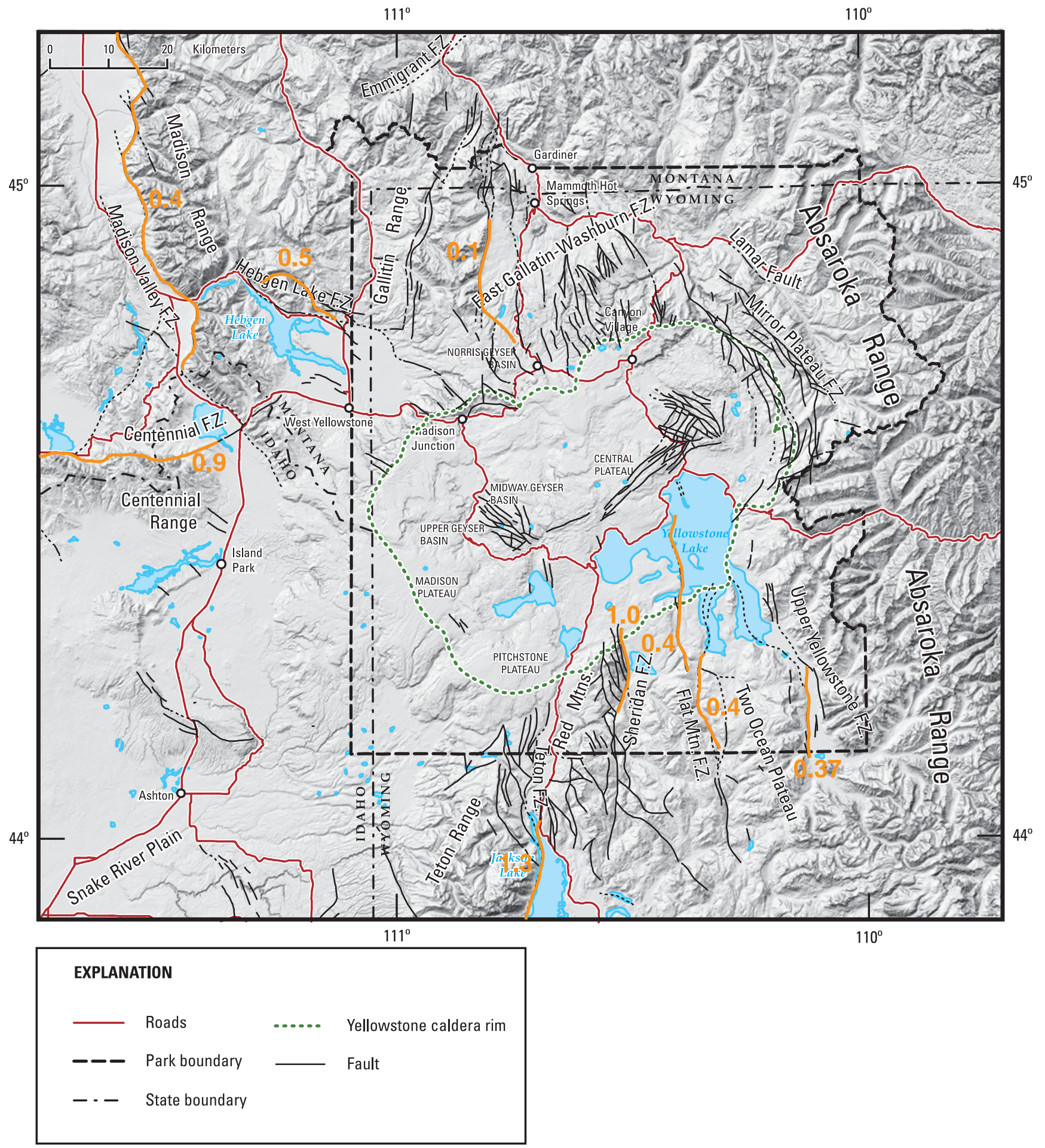

Figure 11. Map of Yellowstone National Park and vicinity showing major faults. All faults shown are normal faults having at least some Quaternary displacement. After Christiansen (2001). Faults in Yellowstone Lake from Morgan and others (in press-b). Faults in orange are those with the largest Quaternary slip rates, as indicated by adjacent numbers in $\mathrm{mm} / \mathrm{y}$ (after White, 2006) 


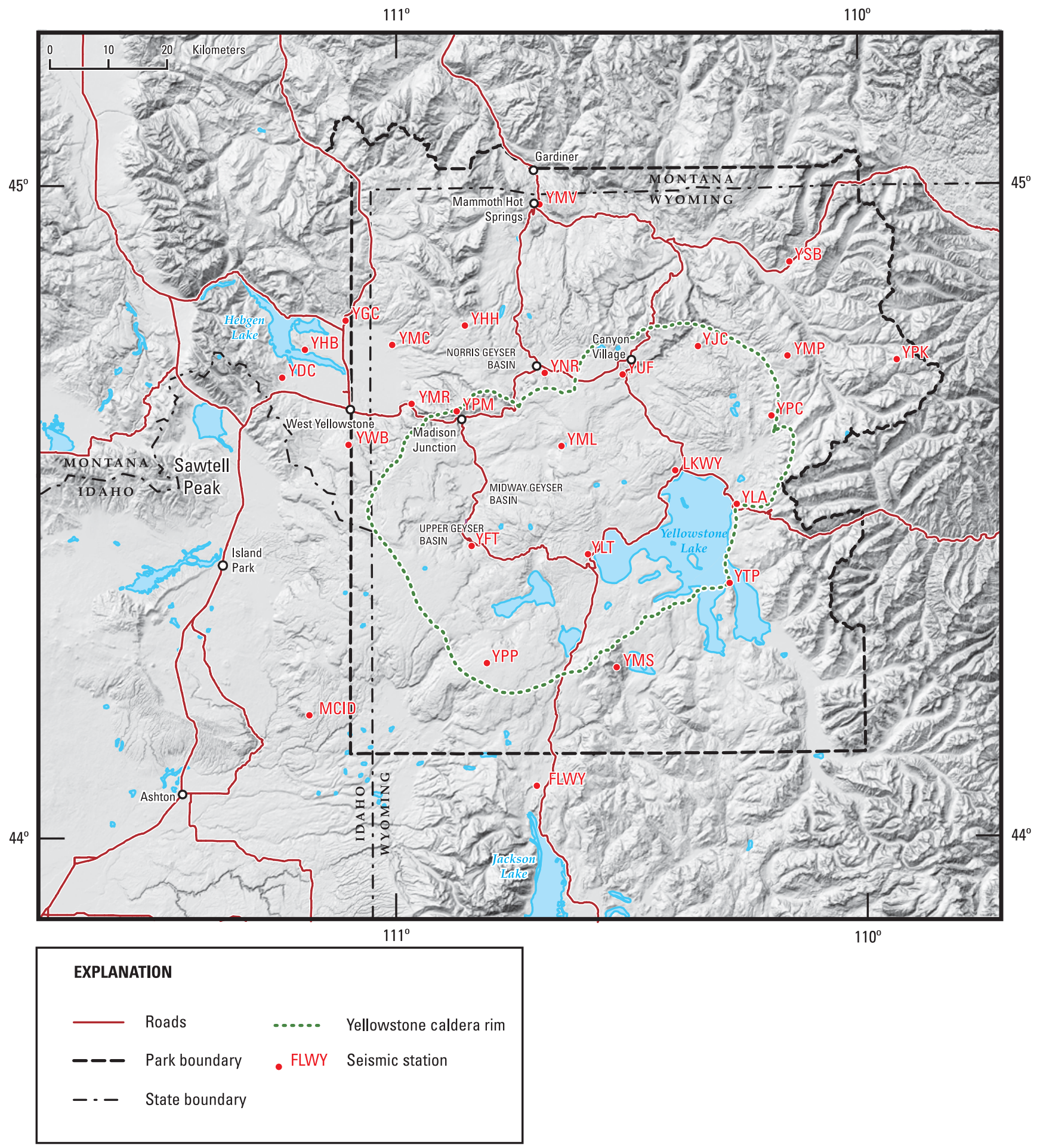

Figure 12. Map of Yellowstone National Park and vicinity showing seismic network of the Yellowstone Volcano Observatory. After Yellowstone Volcano Observatory (2006). 


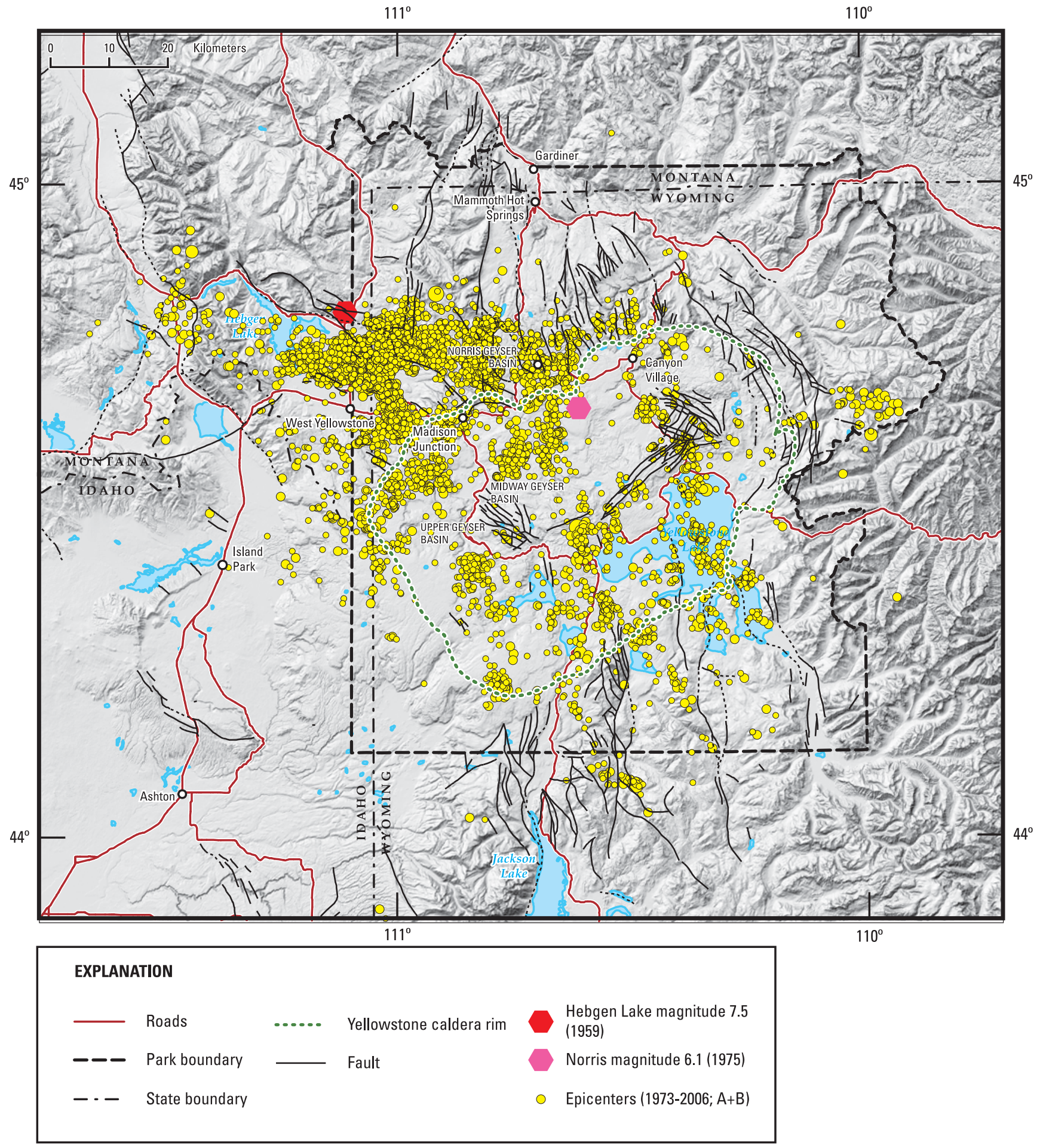

Figure 13. Map of Yellowstone National Park and vicinity showing seismicity between 1973 and 2002 (yellow dots, sizes scaled to relative magnitudes) and major faults having Quaternary displacements. Epicenters of the two largest historic earthquakes in the area are shown by colored hexagons. Data from Yellowstone Volcano Observatory, updated by J. Farrell, University of Utah Seismographic Stations. Only epicenters of classes A and B of Husen and Smith (2004) are shown. 


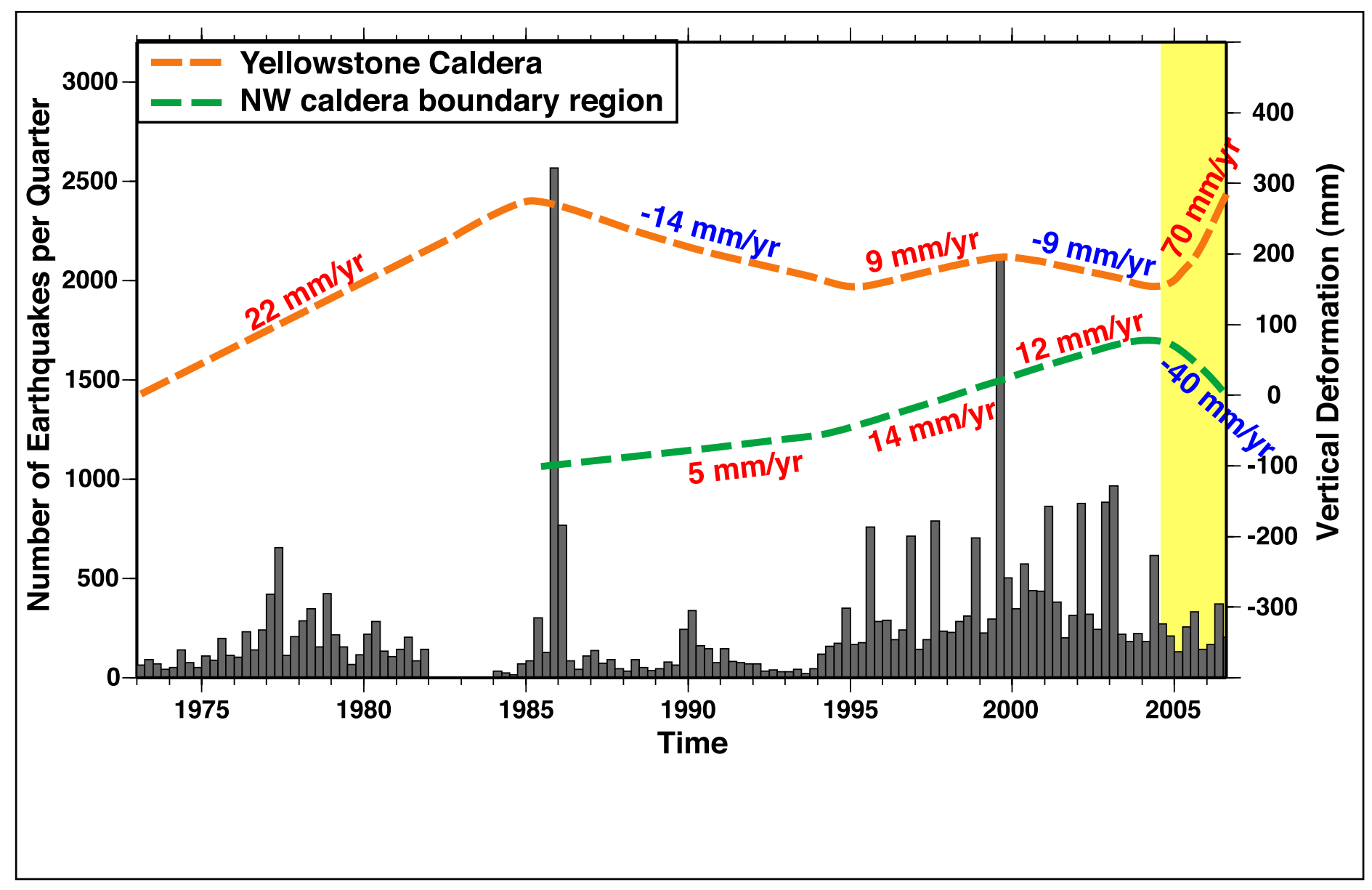

Figure 14. Time history of seismicity in Yellowstone National Park and vicinity, illustrating the swarmlike nature of seismicity and correlation of the swarm of autumn, 1985, with caldera-wide deformation. Earthquakes of magnitudes $M \geq 1.5$ are shown. Yellow shading highlights current episode of accelerated deformation that started about mid-2004. The seismic network was not operational during 1982-1983. (From Puskas and others, 2007). 


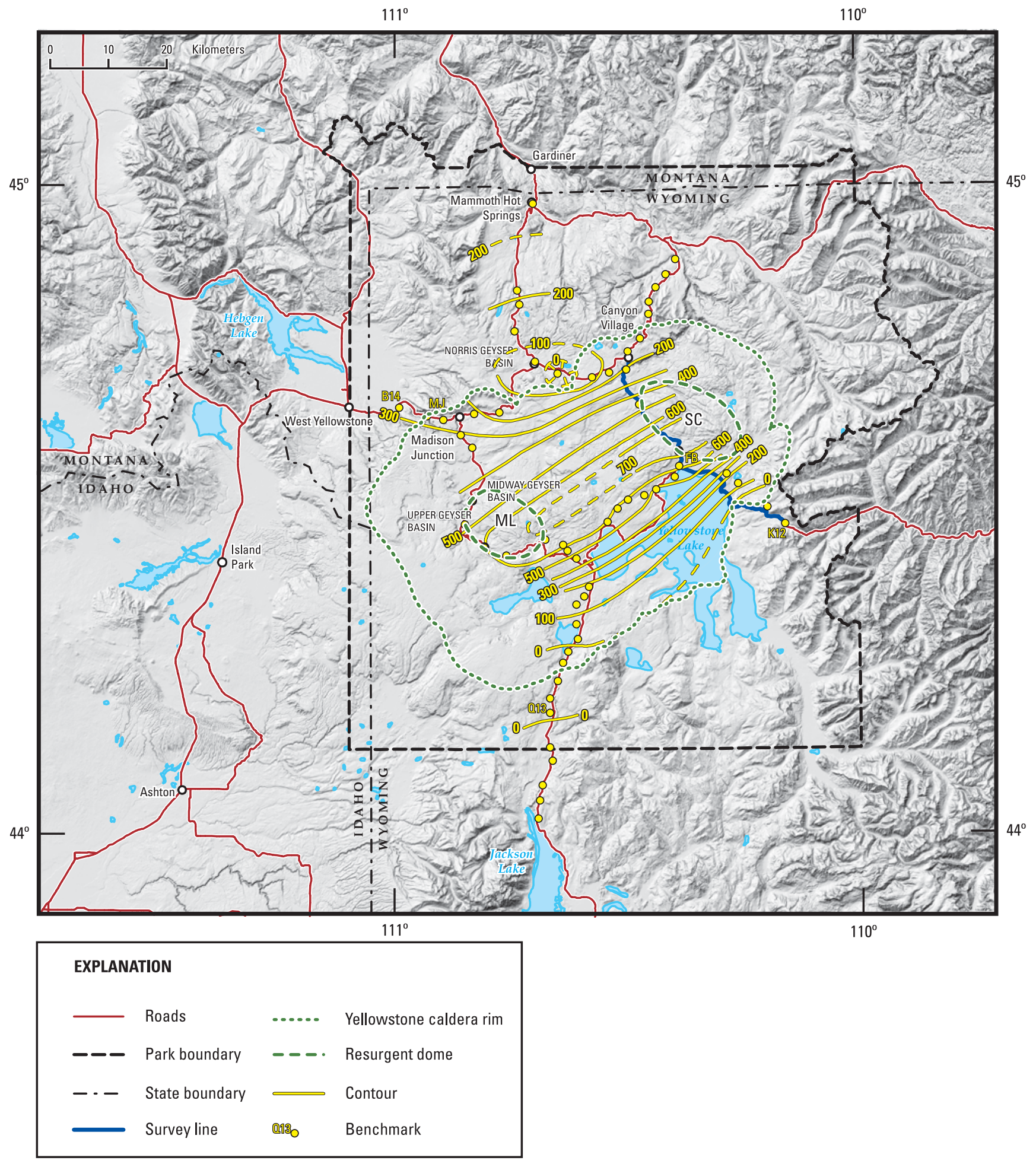

Figure 15. Uplift of the Yellowstone caldera area between 1923 and 1975-1977, based on leveling surveys. Dots represent resurveyed benchmarks. Contours indicate uplift in millimeters during the period between surveys relative to benchmark K12; contour interval $100 \mathrm{~mm}$. (After Pelton and Smith, 1982). The portion of the road shown in blue is the line of the profile in figure 16. 

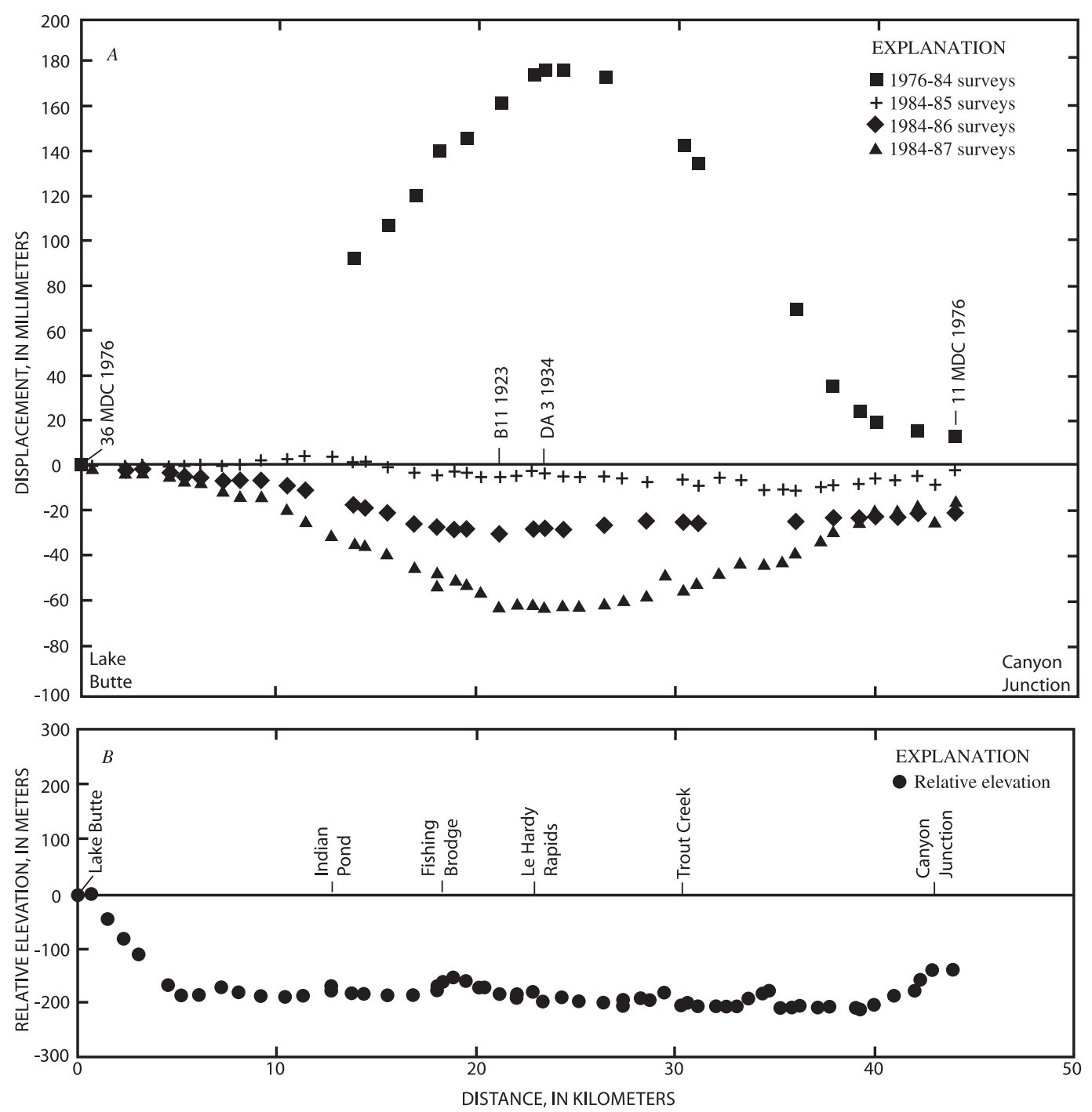

Figure 16. Vertical displacement profiles between Lake Butte and Canyon Junction between 1976 and 1987, based on leveling surveys. (A), Uplift profiles shown by changes in the differences of benchmark elevations relative to Lake Butte between dates indicated. (B), Elevations of benchmarks surveyed relative to Lake Butte. (From Dzurisin and others, 1990). The line of profile is indicated in figure 15. 


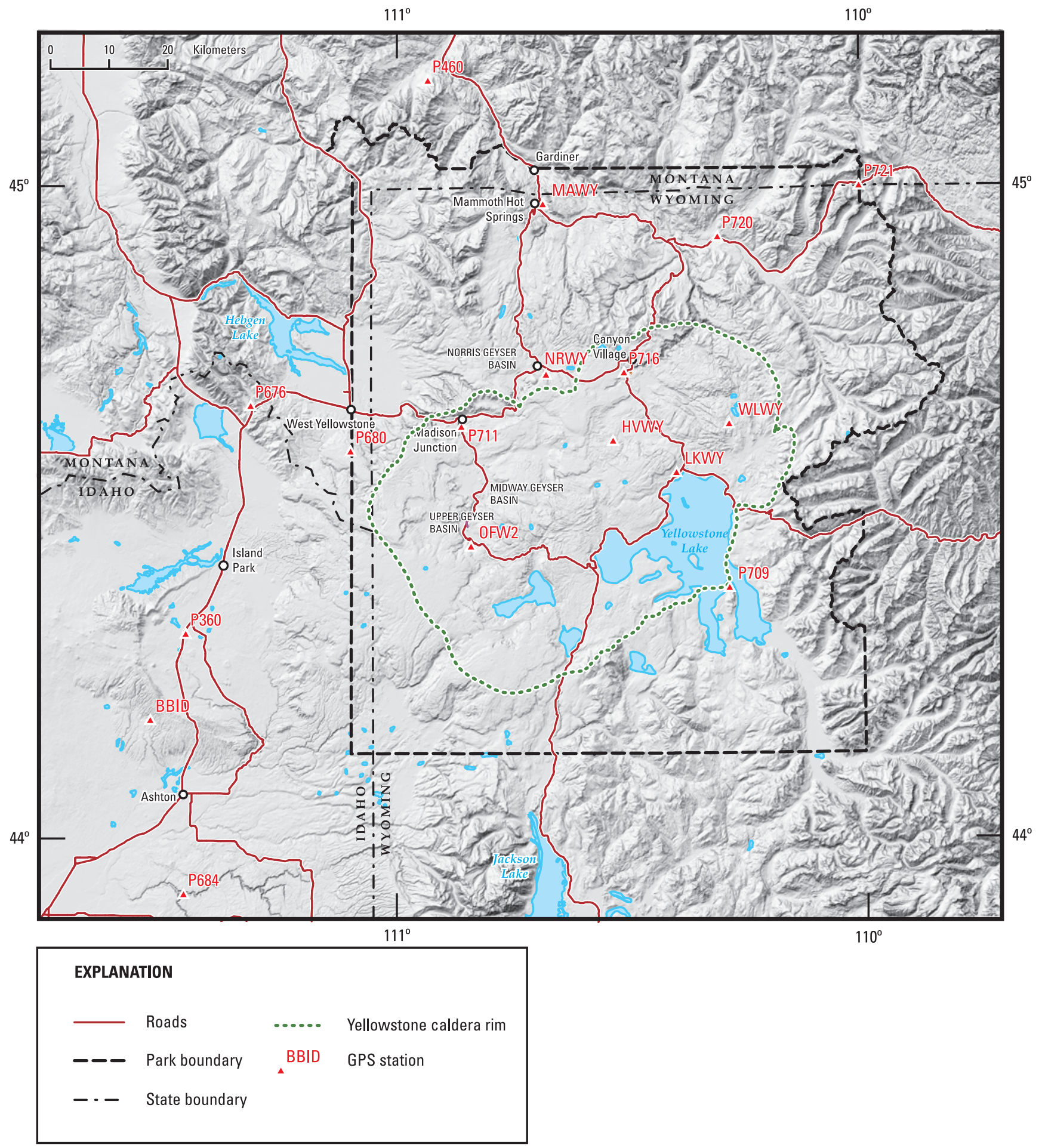

Figure 17. Map of Yellowstone National Park and vicinity showing continuously recording GPS network of the Yellowstone Volcano Observatory, recorded at the University of Utah as part of the National Science Foundation's EarthScope Plate Boundary Observatory, archived at UNAVCO. After Yellowstone Volcano Observatory (2006). 


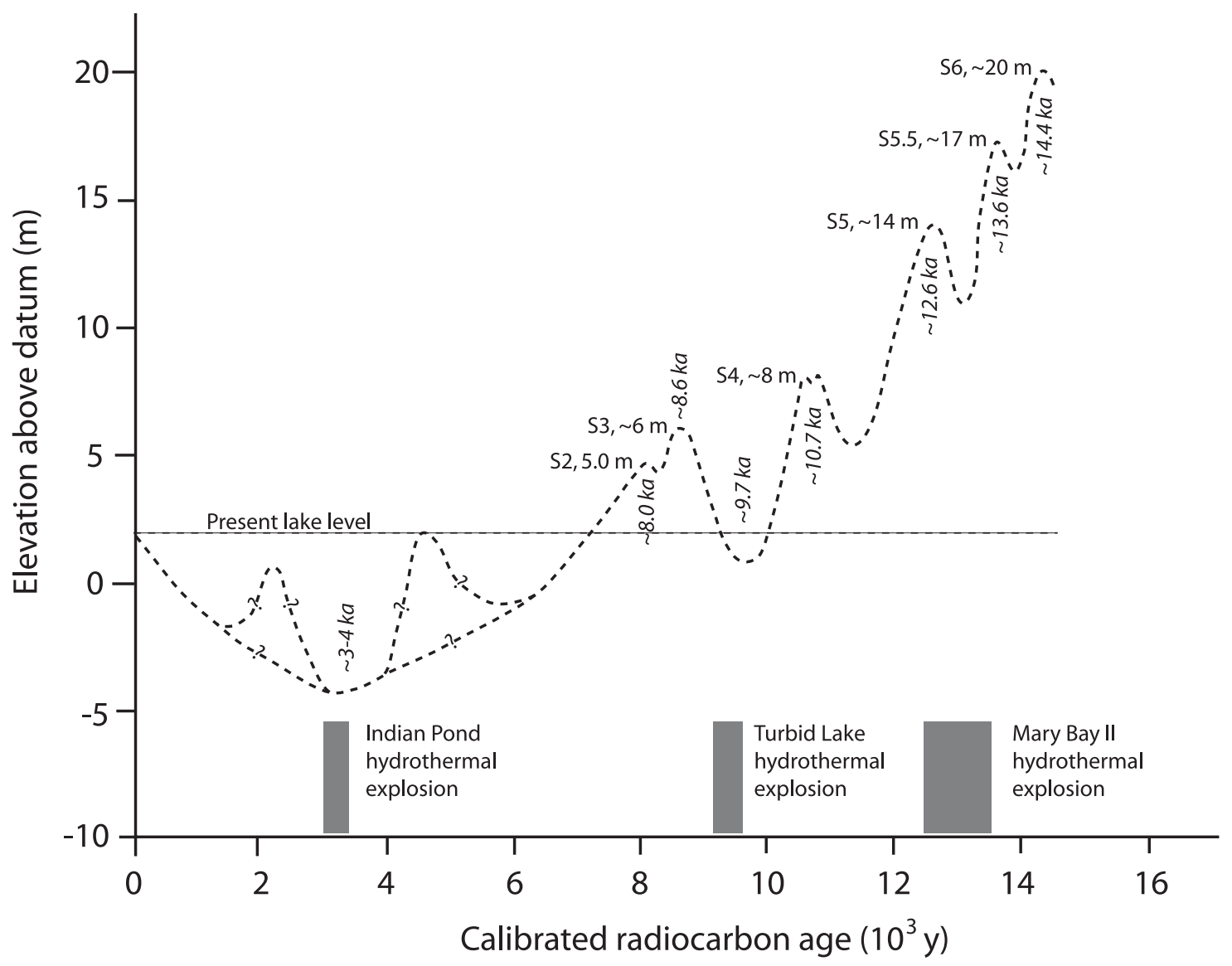

Figure 18. Reconstructed changes in Yellowstone Lake level since $15 \mathrm{ka}$. The dashed line with 9 maxima represents shoreline elevations for the northern lake area relative to the lake gage at Bridge Bay Marina. S2, S3, S4, S5, S5.5, and $S 6$ are numbered shorelines with elevations as indicated. Datum is the elevation of LeHardy Rapids, the erosional base level $\sim 4.5 \mathrm{~km}$ north of the lake outlet. The general decline in elevations from 14.4 to 3-4 ka represents mainly decreasing levels as the lake outlet eroded its base level, but the shorter increases in level represent uplift of the Yellowstone caldera, as does the overall increase from 3-4 ka to present. The queried curves between $\sim 6.5 \mathrm{ka}$ and 0 ka represent alternative possible elevation-change paths allowed by the data. Modified from Pierce and others (2002). 

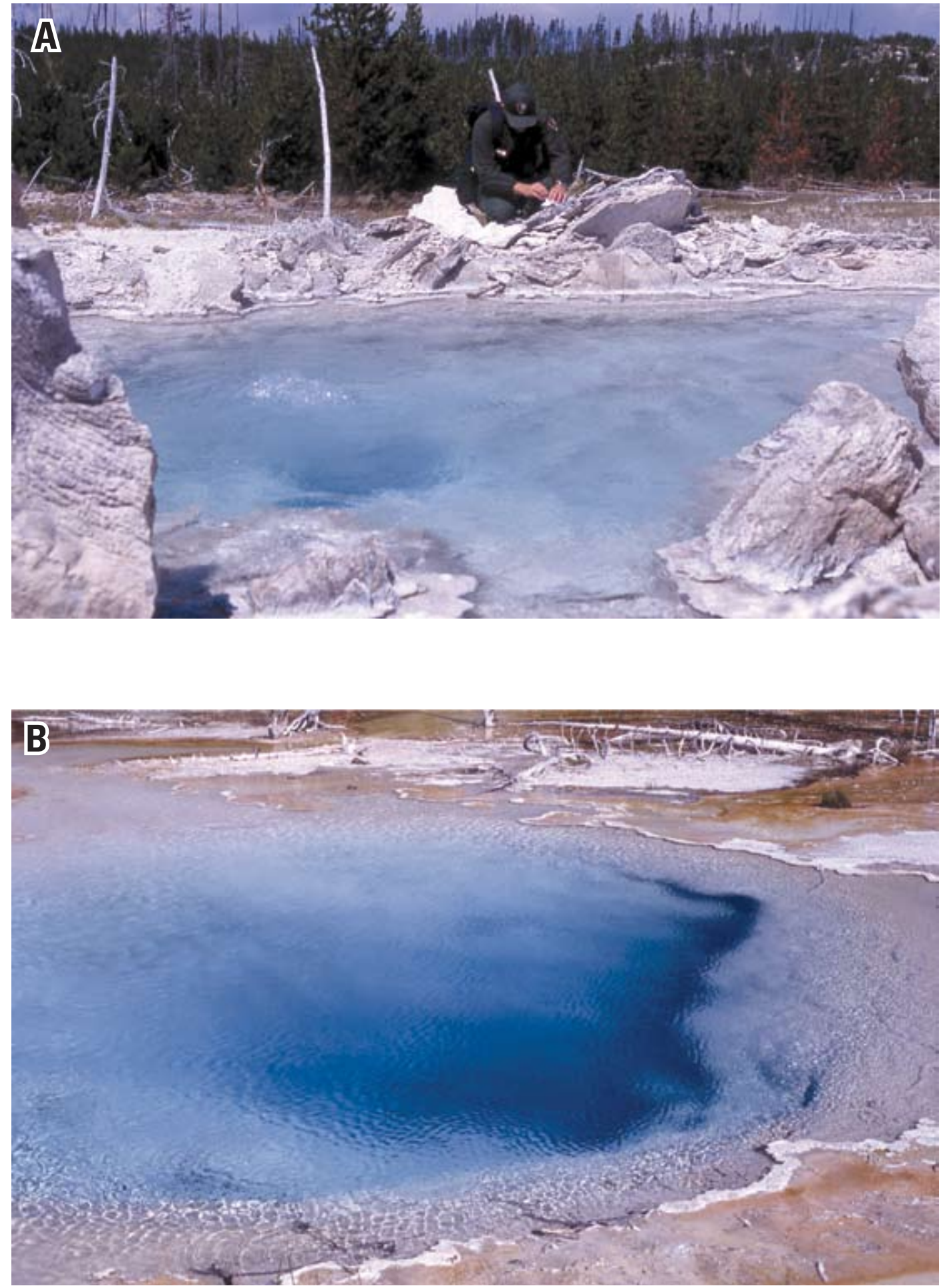

Figure 19. A. Porkchop Geyser, in the Norris Geyser Basin, formed by a hydrothermal explosion in September 1989 (Fournier and others, 1991). Blocks of silica sinter thrown from the geyser's throat form a berm around the new crater. The silica will likely continue to dry out and disaggregate over time, subduing evidence of the explosive activity. Photo by Jim Peaco, 2003 (NPS stock photo). B. Silex Spring, in the Lower Geyser Basin, like many other pools, has a shape and jagged sides suggestive of a similar origin. Photo by Carolyn Duckworth, 2002 (NPS stock photo). 


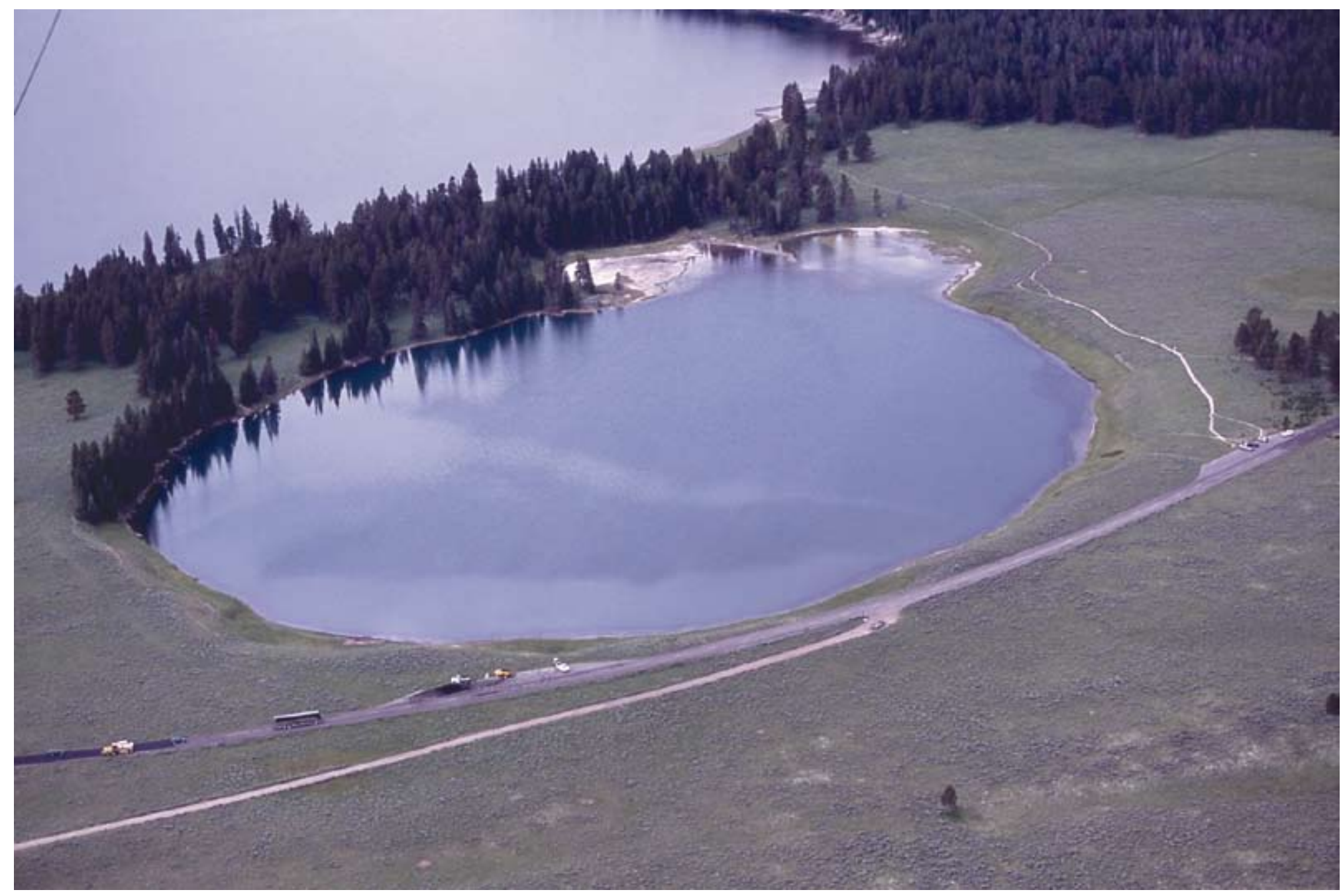

Figure 20. Indian Pond, just north of Yellowstone Lake, is about 500 meters in maximum diameter and was formed about 3000 years ago by a hydrothermal explosion (Morgan and others, in review). Photo by Jim Peaco, 2001 (NPS stock photo). 


\section{Temperature in ${ }^{\circ} \mathrm{C}$}

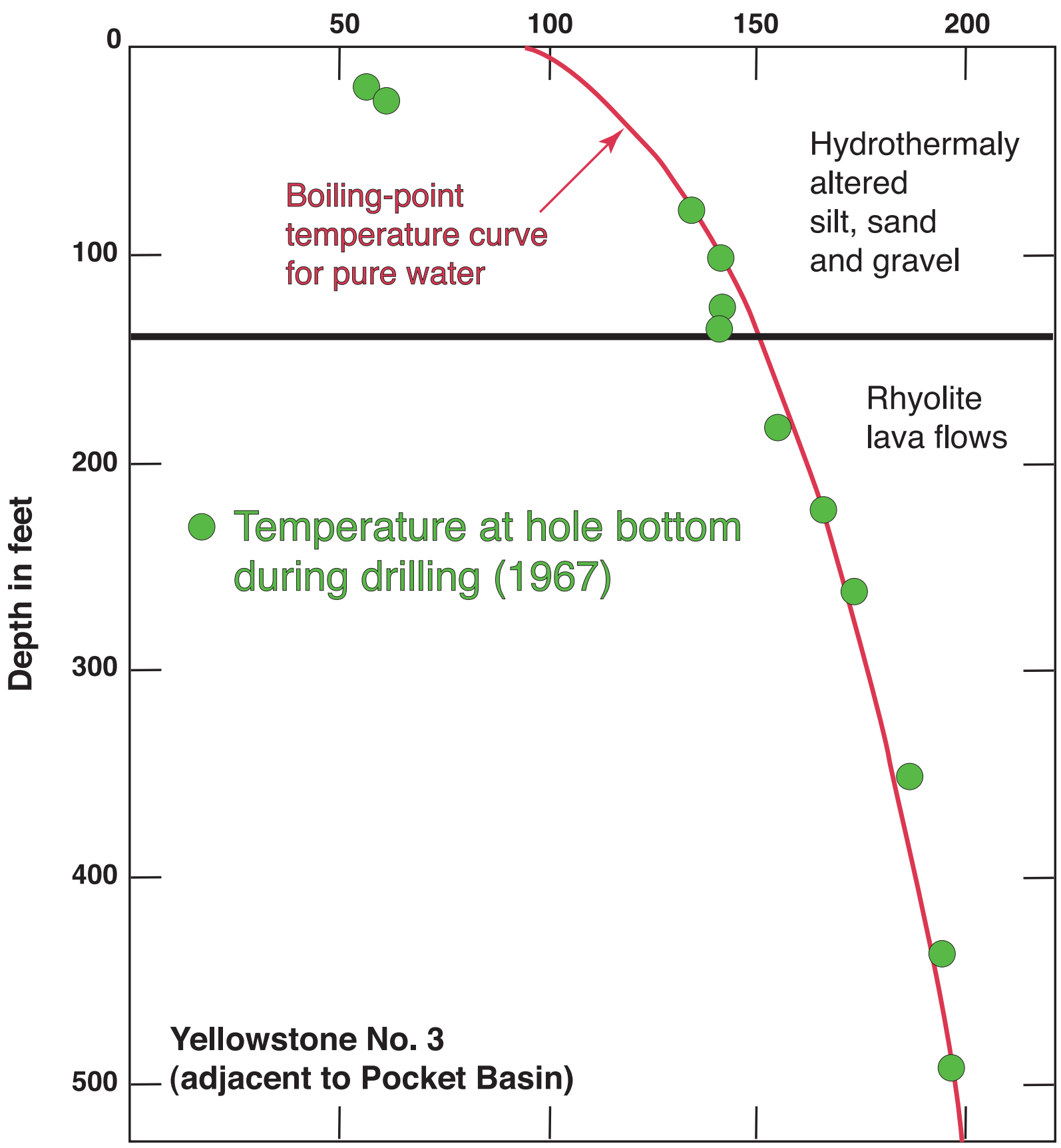

Figure 21. Temperature vs. depth for a column of water at its boiling point (red line) and actual temperatures within a research hole drilled near Pocket Basin, Yellowstone National Park in 1967 (green circles). The well is located in glacial sediments until reaching a depth of $\sim 140 \mathrm{ft}$, where it enters rhyolitic lavas. Adapted from figure 2 of Muffler and others (1971). 


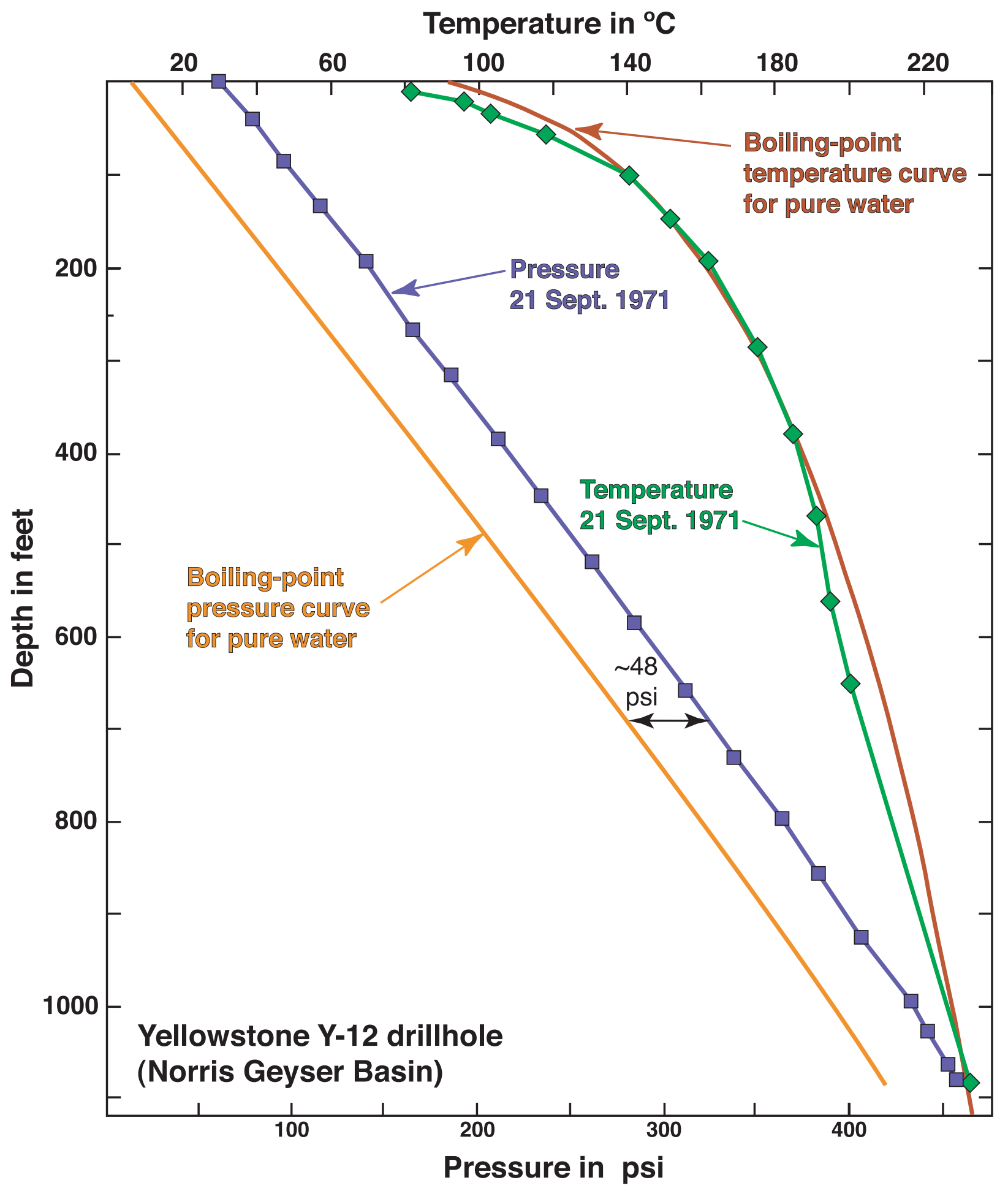

Figure 22. Temperature and pressure vs. depth for a column of water at its boiling point (red and orange lines), and actual temperatures (green diamonds) and pressures (blue squares) within a research hole drilled at the Norris Geyser Basin, Yellowstone National Park in 1971. Note that the measured fluid pressure is about $0.33 \mathrm{MPa}$ (48 psi) above the reference curve for boiling water. Adapted from figure 30 of White and others (1975). 


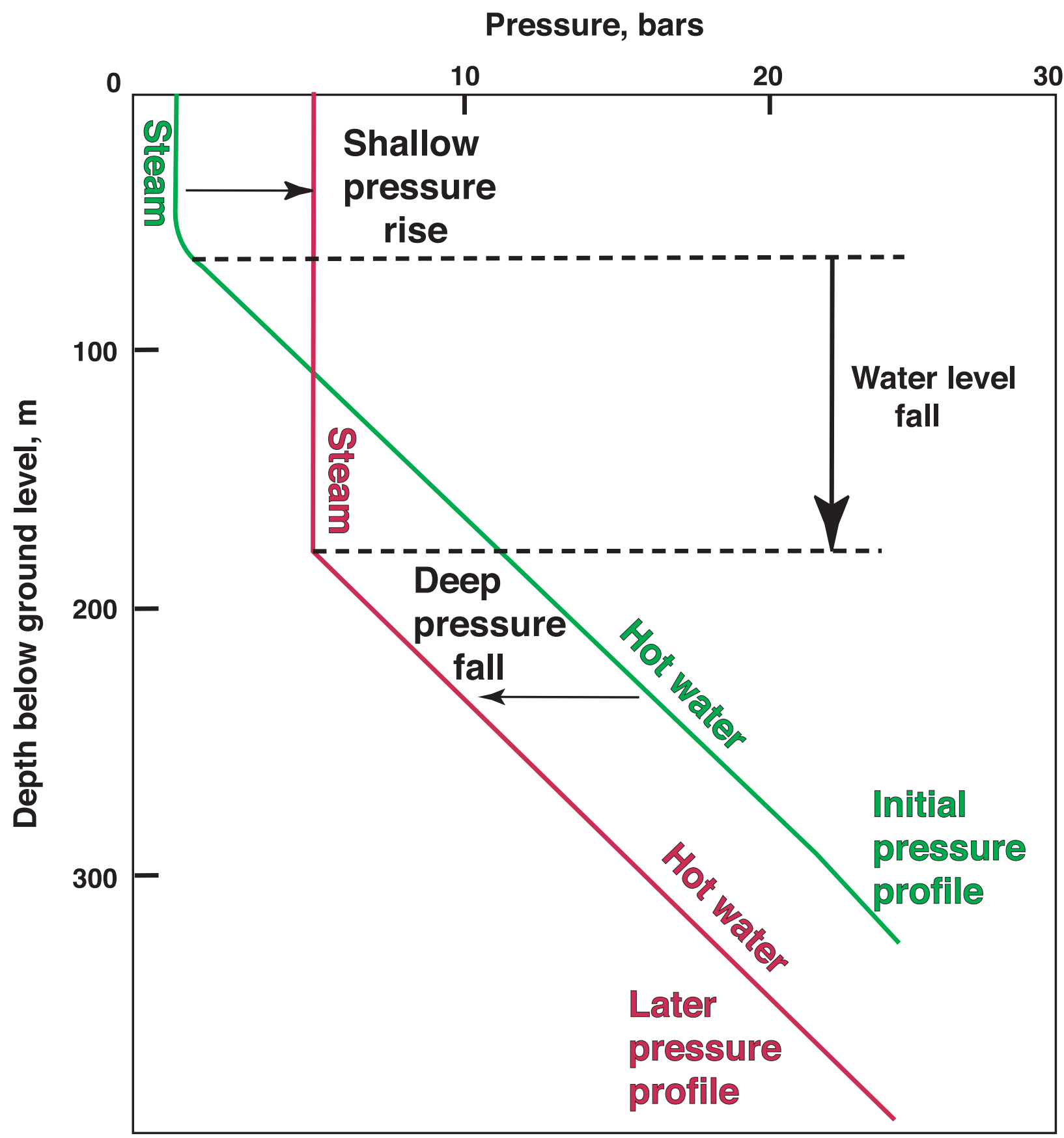

Figure 23. Conceptual plot of pressure vs. depth for a schematic shallow geothermal system sealed from the surface. The green curve illustrates an initial pressure profile for a boiling geothermal (liquid) reservoir capped by an $~ 75$-m-thick steam/vapor zone. A drop in the water level causes a decrease in the deep pressure from $\sim 1.1 \mathrm{MPa}$ to $\sim 0.5 \mathrm{Mpa}$ (11 to 5 bars). To stay in equilibrium with the deep liquid, the vapor pressure impinging on the surface rises from $\sim 0.1 \mathrm{MPa}$ to $\sim 0.5 \mathrm{Mpa}$ ( 1 to 5 bars). Modified from figure 6 of Browne and Lawless (2001). 


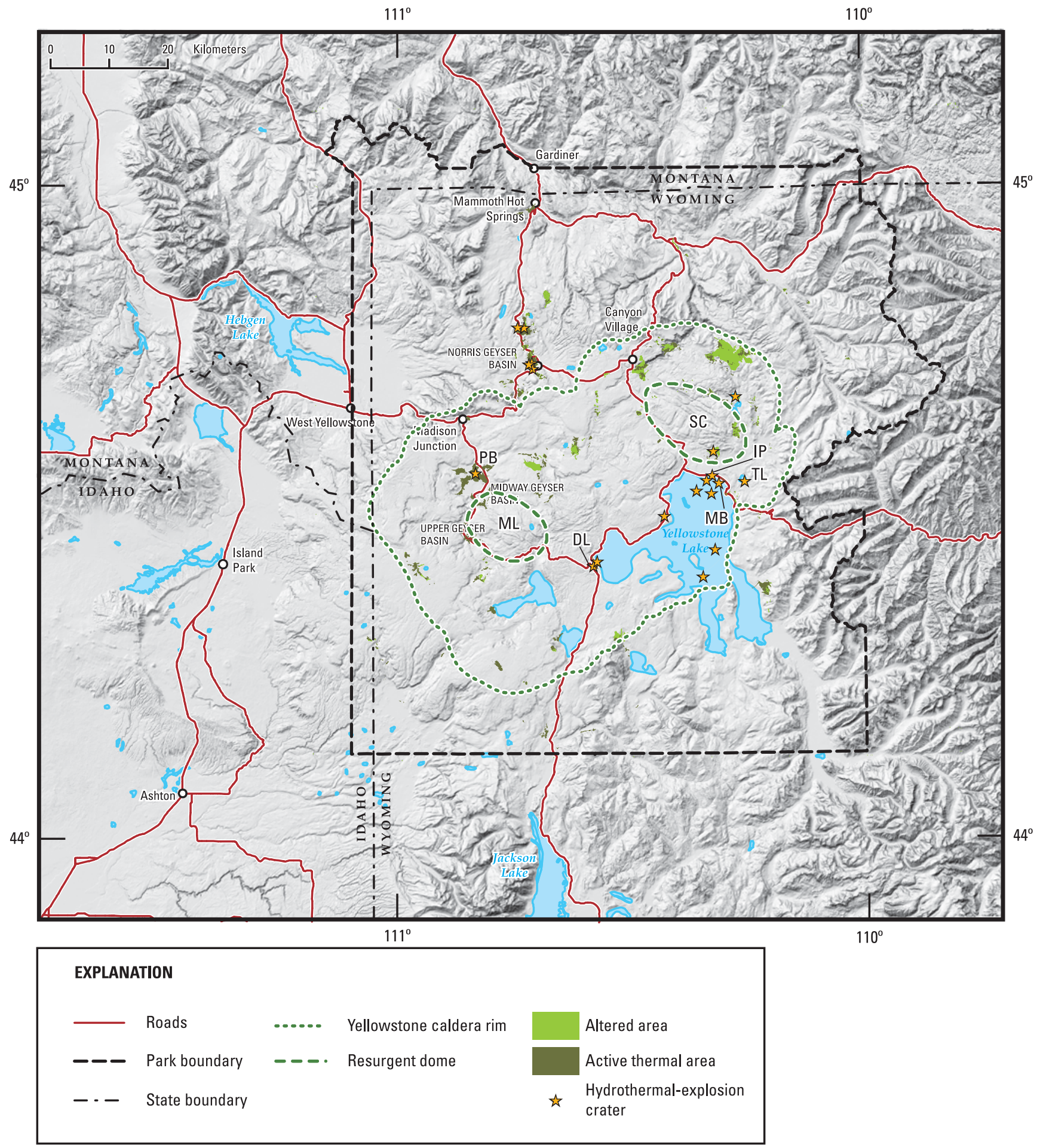

Figure 24. Map of Yellowstone National Park and vicinity, including geothermal areas (green) and hydrothermal-explosion craters $>100 \mathrm{~m}$ in diameter that formed within the past 14,000 years (from Morgan and others, in review). Explosion Craters named in text: DL, Duck Lake; IP, Indian Pond; MB, Mary Bay; PB, Pocket Basin; TL, Turbid Lake. ML, Mallard Lake resurgent dome; SC, Sour Creek resurgent dome. 


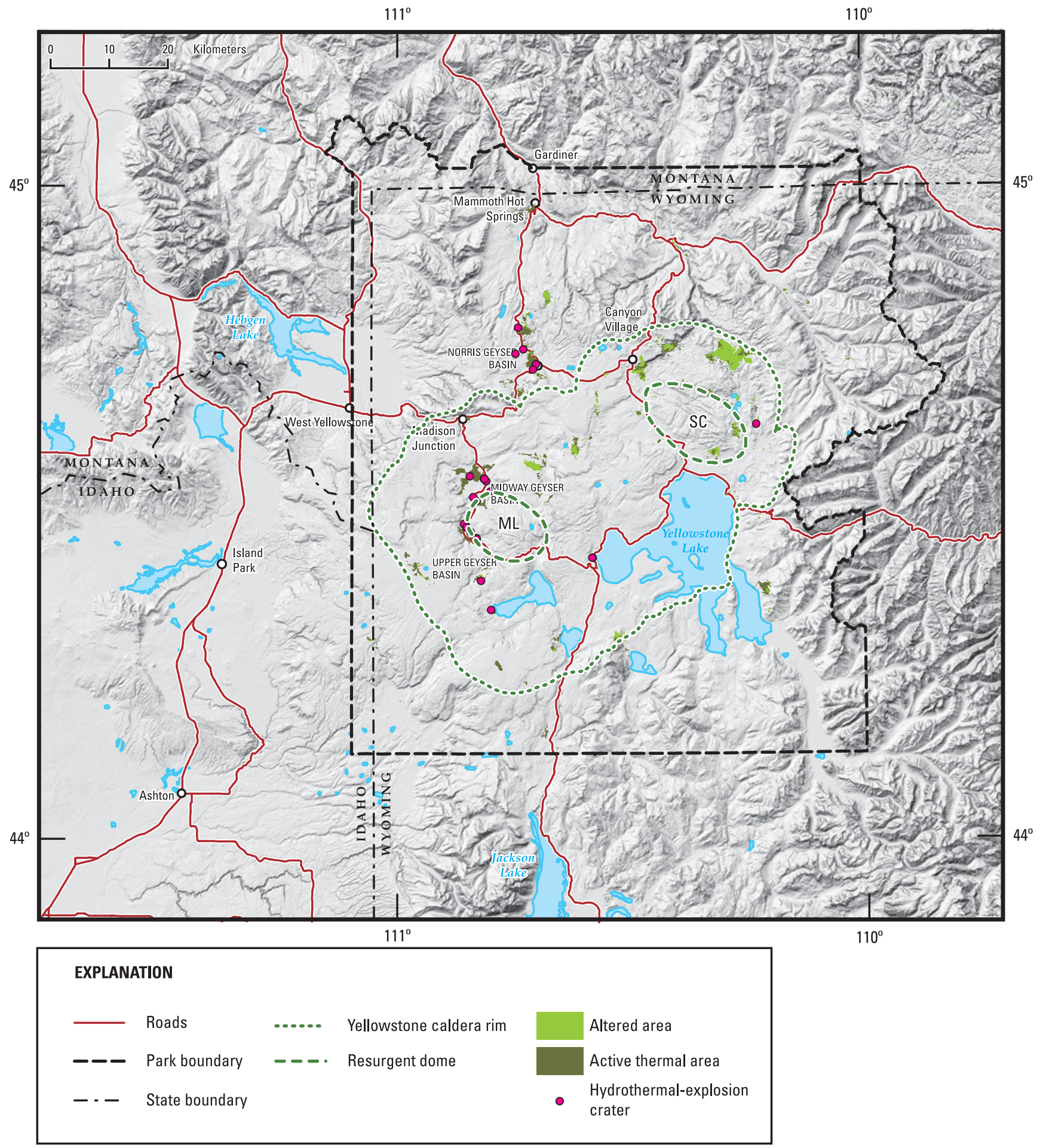

Figure 25. Map of Yellowstone National Park and vicinity, including geothermal areas (green) and hydrothermal-explosion craters formed since historical records have been kept, about 1872. The list of historic explosions may not be complete, primarily because record keeping has been irregular and relevant archives are not easily accessible. ML, Mallard Lake resurgent dome; SC, Sour Creek resurgent dome. 


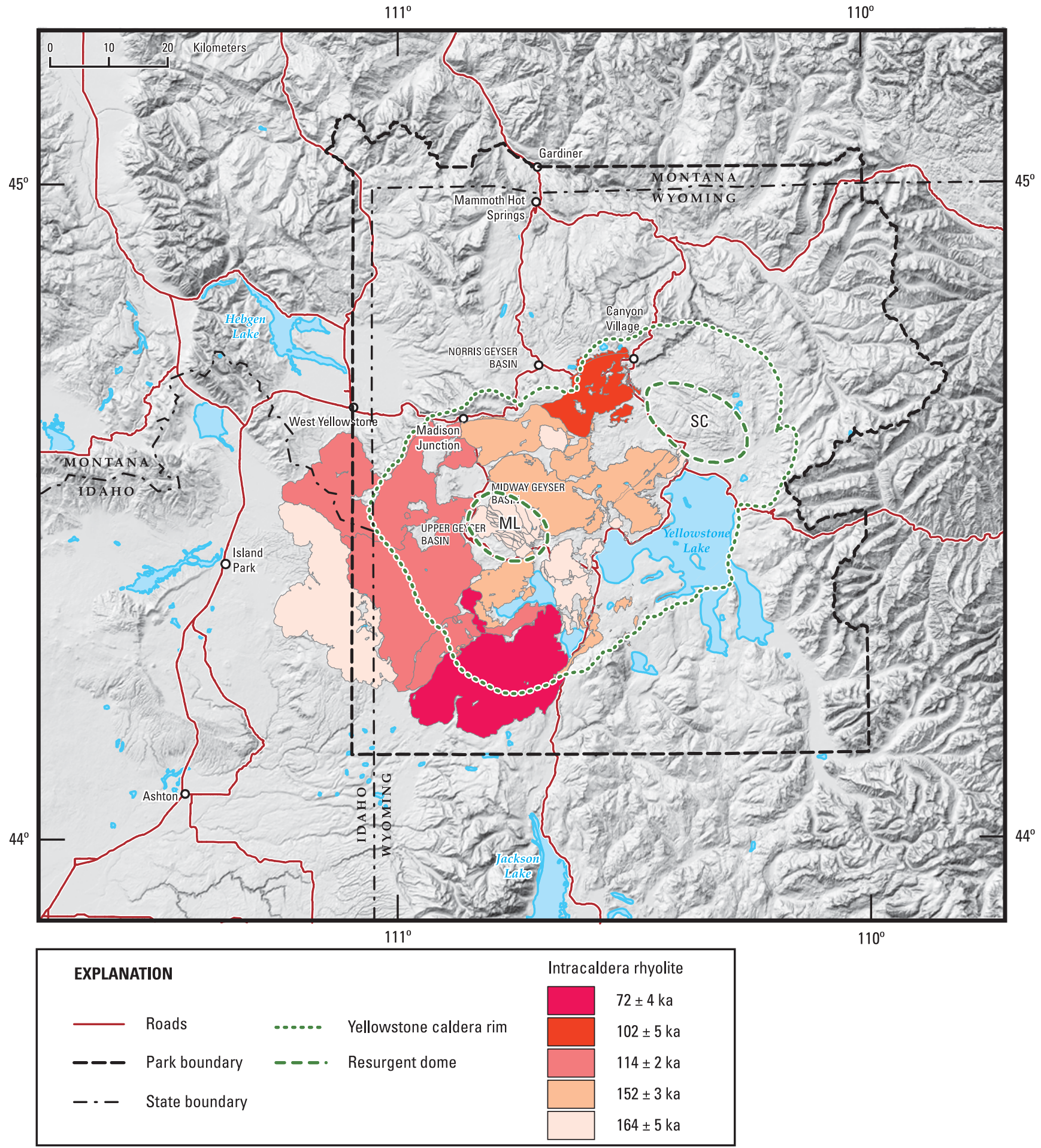

Figure 26. Map of Yellowstone National Park and vicinity showing sequence and ages of known postcollapse rhyolitic lava flows $\leq 170$ ka within the Yellowstone caldera. ML, Mallard Lake resurgent dome; SC, Sour Creek resurgent dome. After Christiansen (2001). 


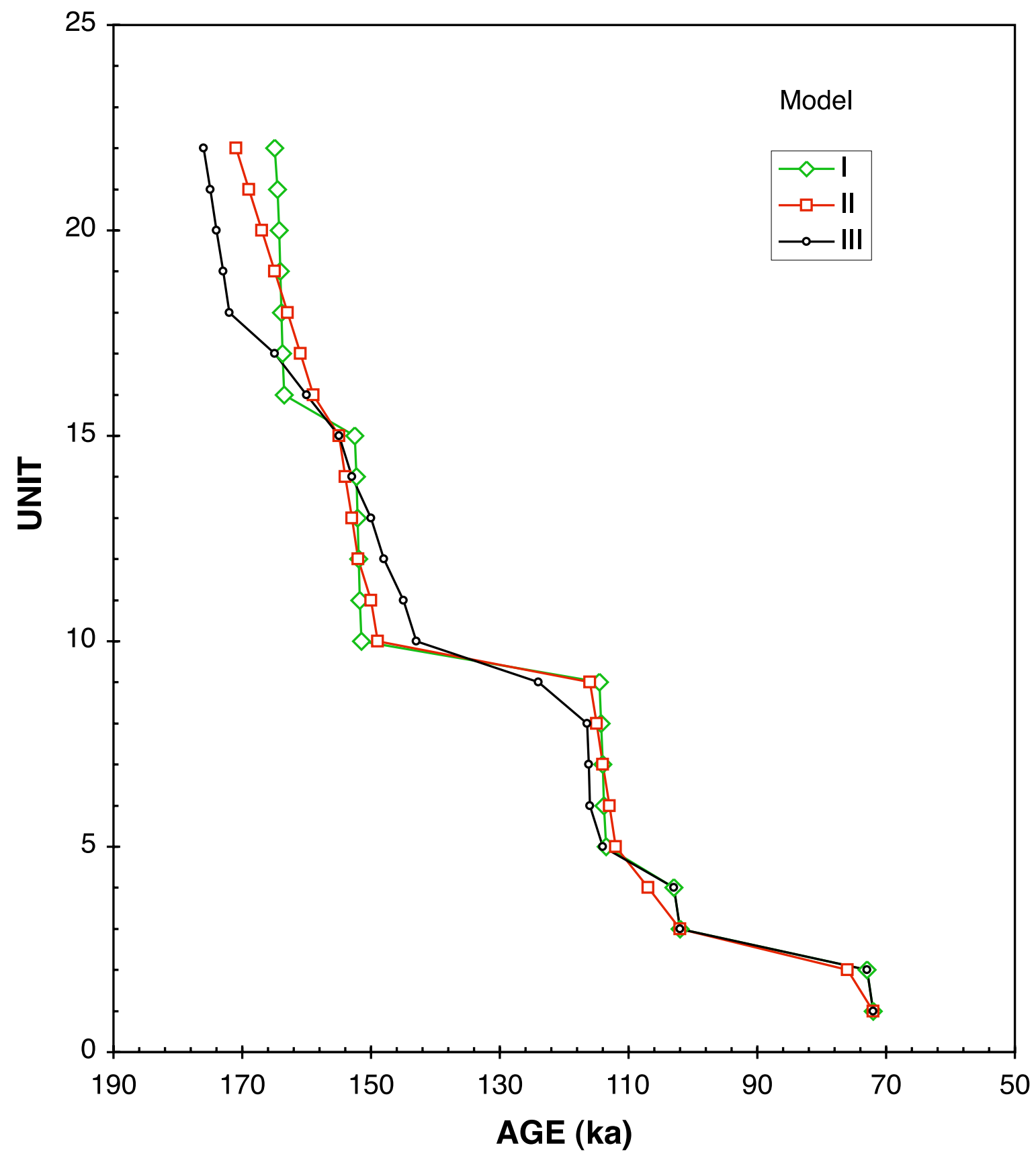

Figure 27. Ages and sequence of Yellowstone intracaldera rhyolitic lava eruptions younger than $\sim 170 \mathrm{ka}$. The ages define 5 relatively brief eruptive episodes, separated by longer time intervals. Uncertainties in ages of individual eruptions within episodes are analyzed with models I, II, and III (see text, appendix 3). 

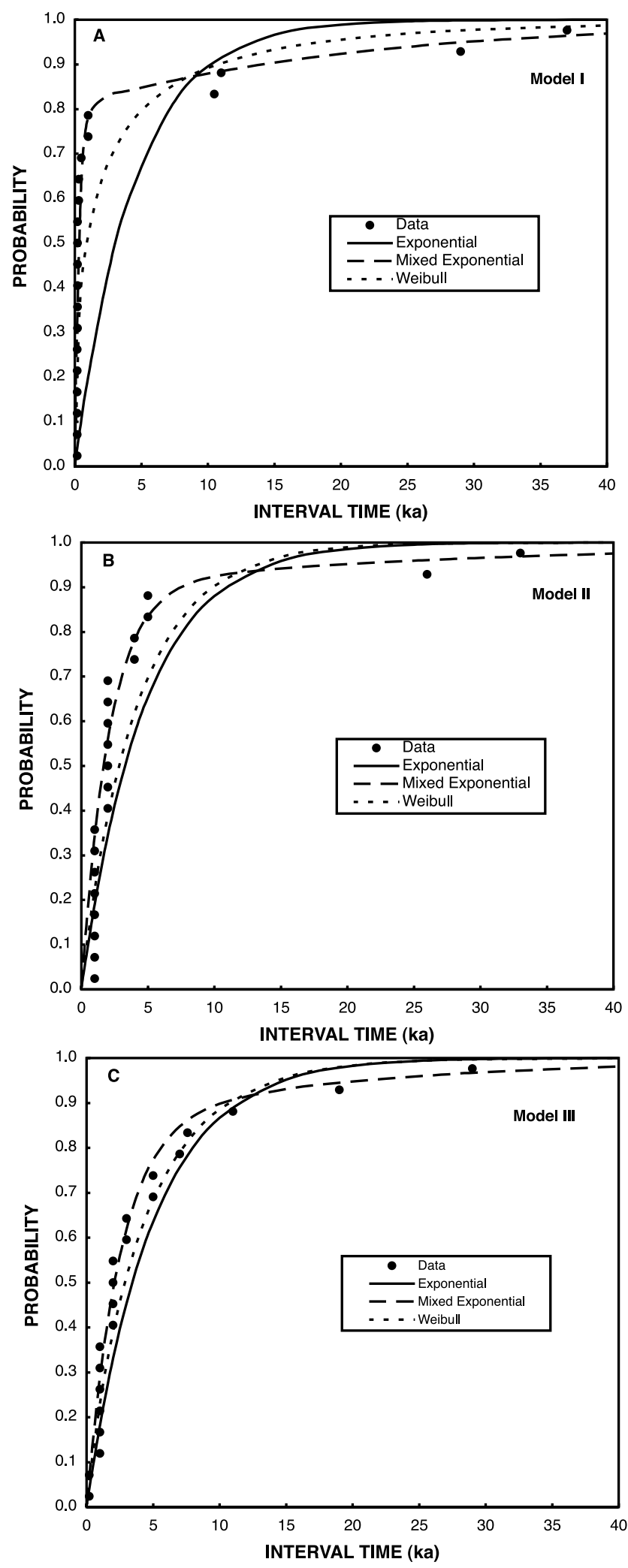

Figure 28. Probability of an intracaldera rhyolitic lava eruption in a time less than a given intereruptive interval. Dots are the data, based on ages in table 6 and figure 27; curves are model probability distributions (see text, appendix 3). 

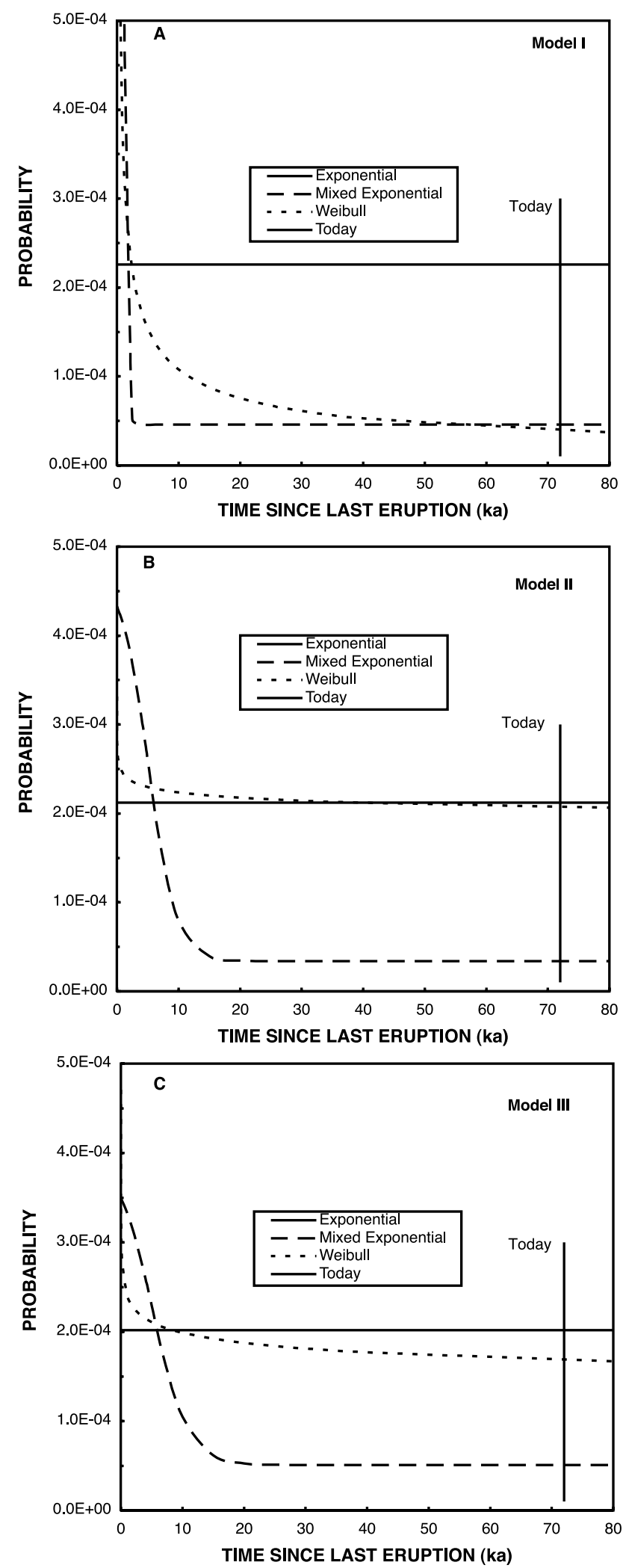

Figure 29. Conditional probability that an intracaldera rhyolitic lava eruption will occur in the next year, given a time since the last such eruption. Curves are based on the same three model distributions as in figure 28. The time since the last known intracaldera eruption indicated by the vertical line labeled "Today". 


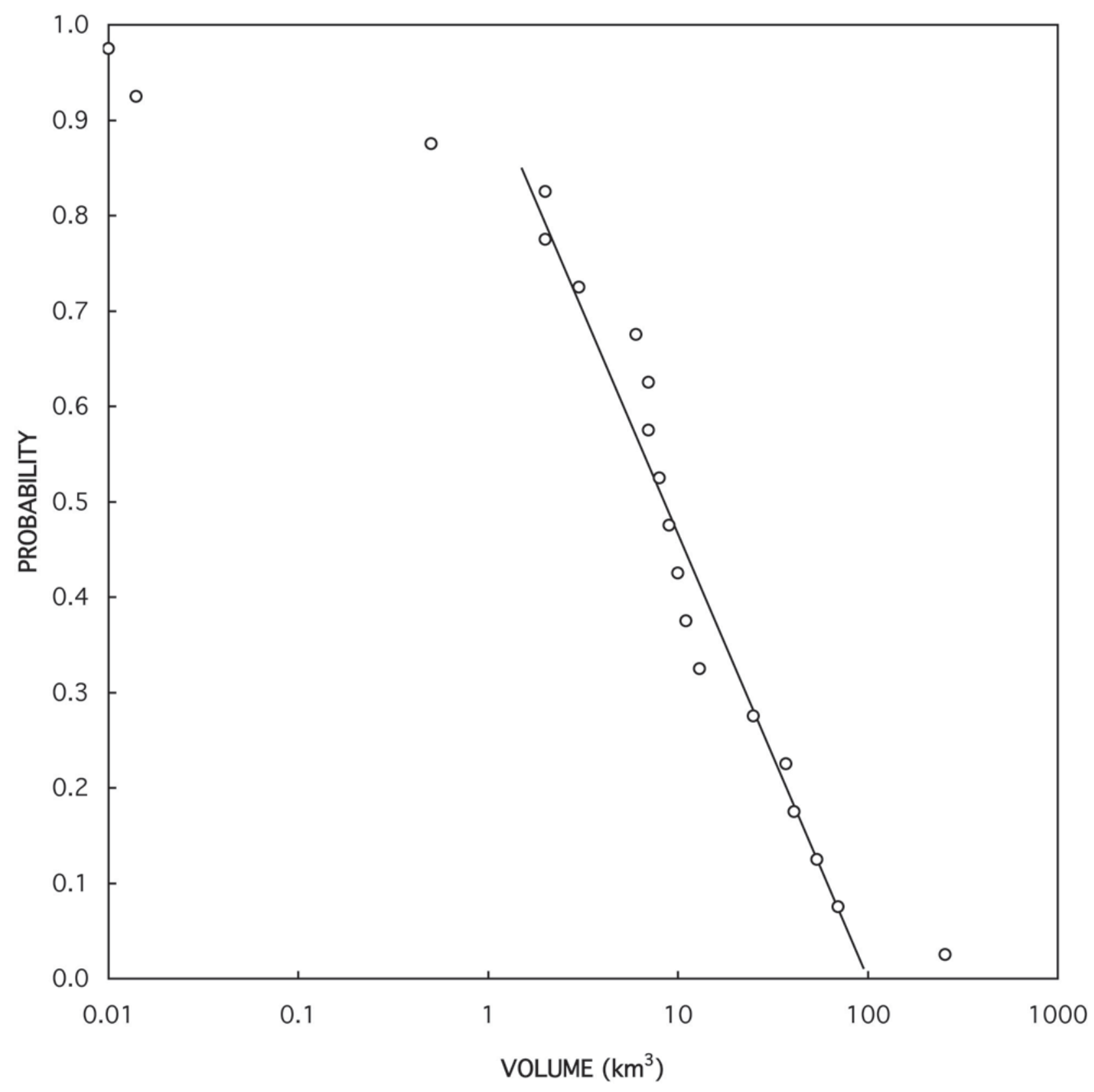

Figure 30. Probability that the next intracaldera rhyolitic lava flow will have a volume greater than a given value. 


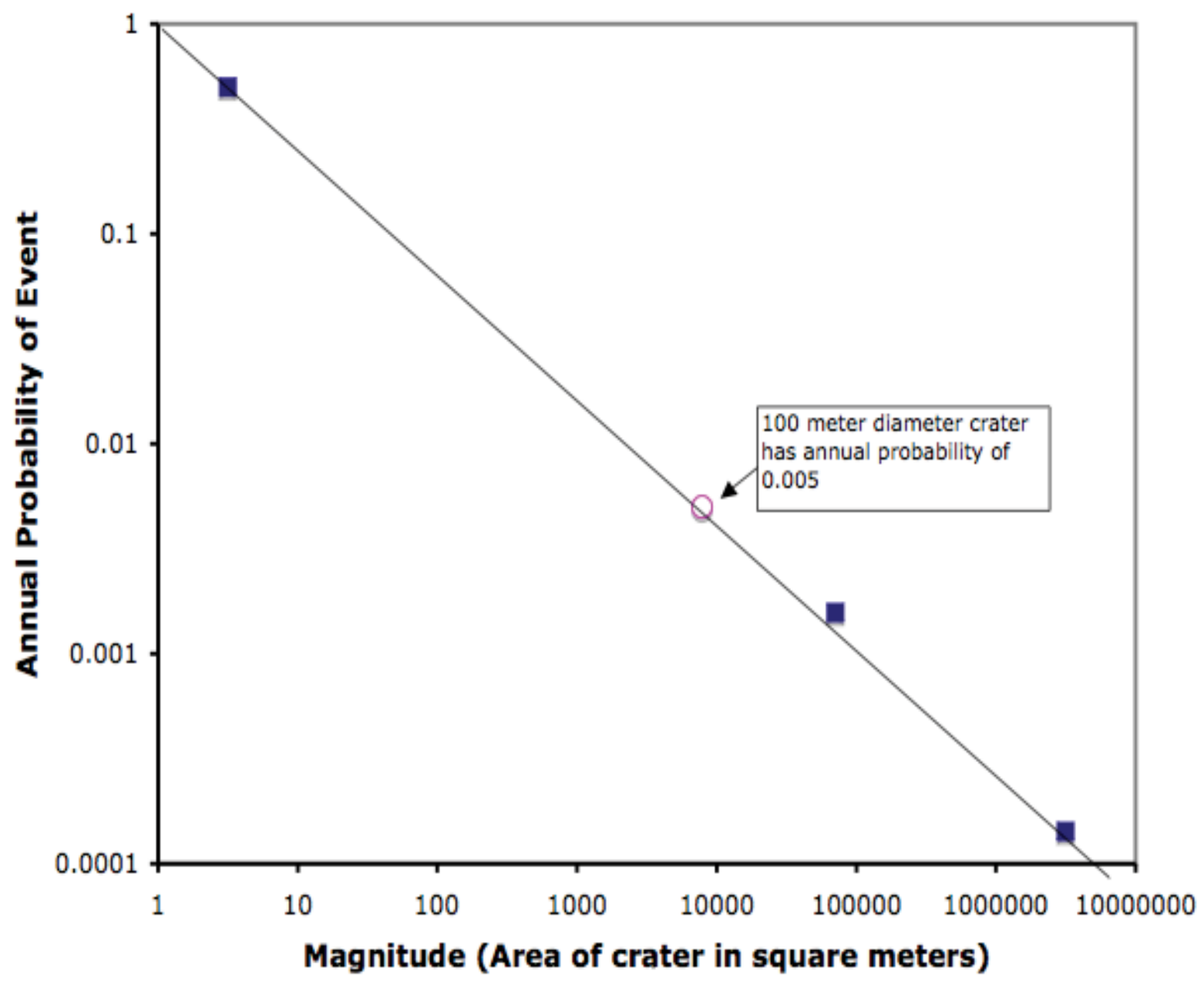

Figure 31. Plot of size vs. annualized probability for hydrothermal-explosion craters at Yellowstone National Park. The three blue squares represent categories of existing craters (see text) and their annualized probability. Assuming the three points form a trend, one could predict that a crater with diameter $>100$ meters (area $=7850 \mathrm{~m}^{2}$ ) would have a mean recurrence interval of 200 years (red unfilled circle). 
Table 1. Ages of volcanic units related to the third cycle of the Yellowstone Plateau volcanic field.

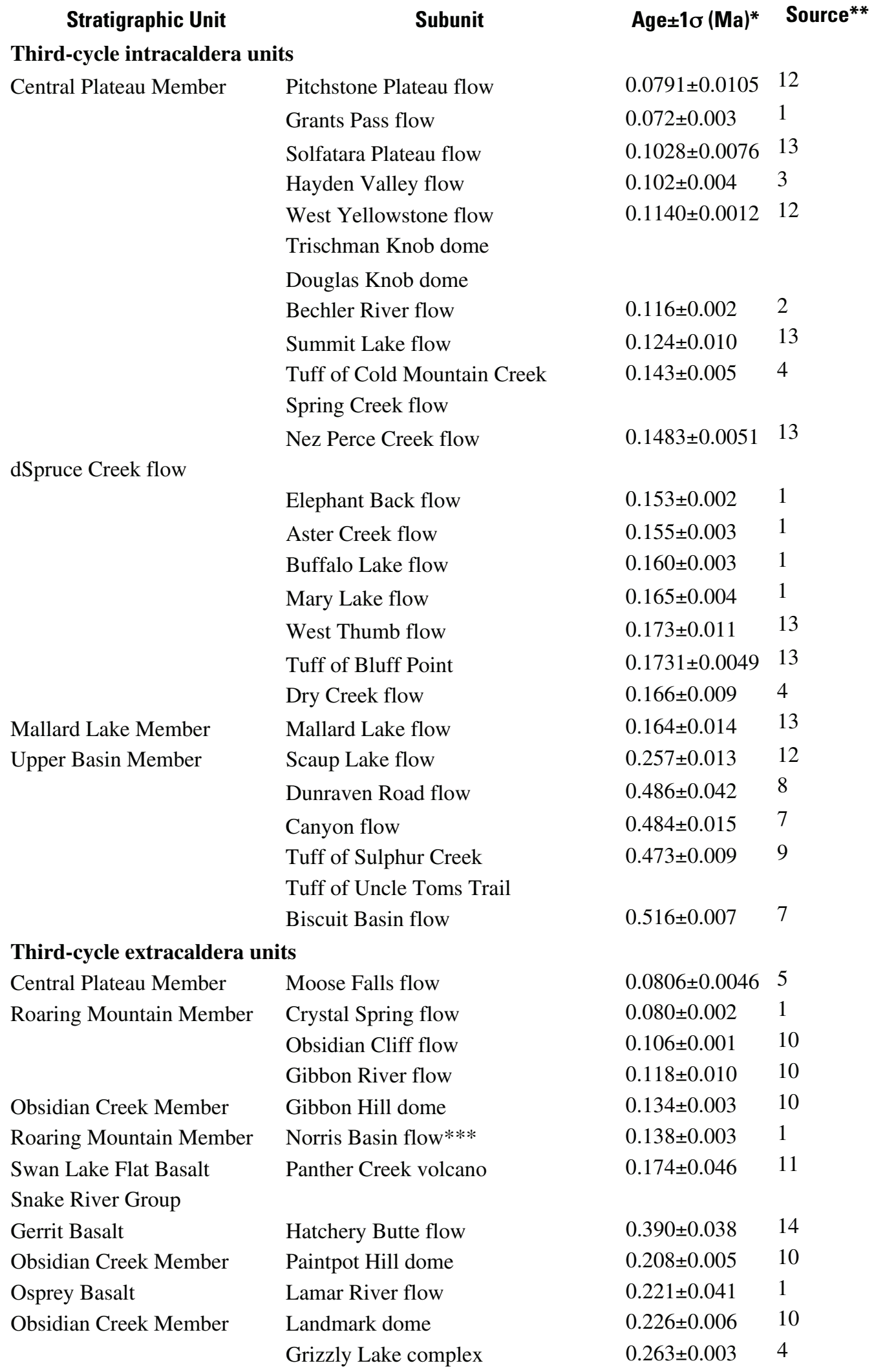




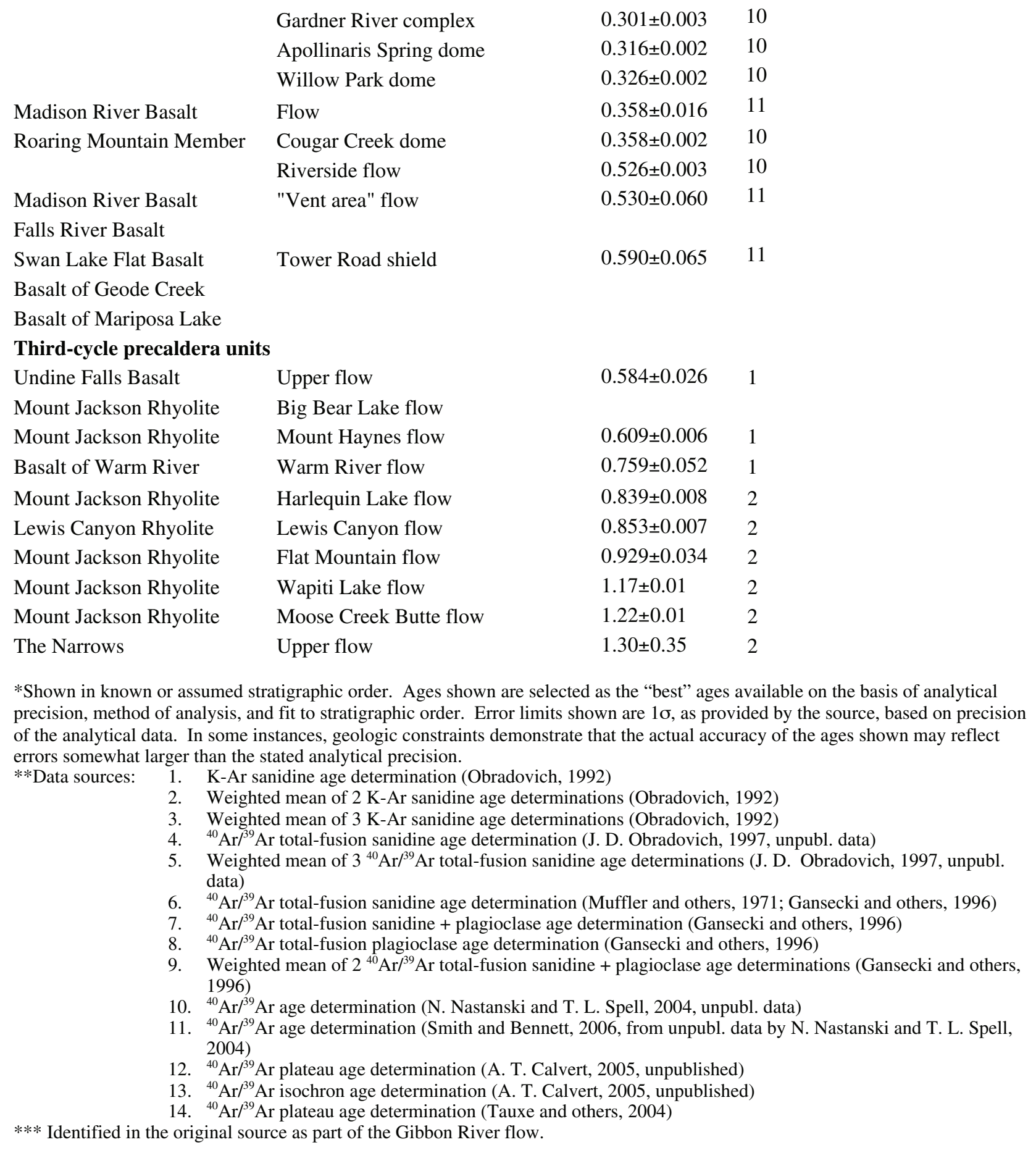


Table 2. Age, area, and volume of late postcaldera lavas of the third cycle of the Yellowstone

Plateau volcanic field.

\begin{tabular}{|c|c|c|c|c|c|c|c|}
\hline Name of flow & $\begin{array}{c}\text { Age } \pm 1 \sigma \\
\text { (ka) }\end{array}$ & $\begin{array}{l}\text { Mean Group } \\
\text { Age } \pm 1 \sigma \\
\text { (ka) }\end{array}$ & $\begin{array}{l}\text { Area } \\
\left(\mathrm{km}^{2}\right)\end{array}$ & $\begin{array}{l}\text { Volume } \\
\left(\mathrm{km}^{3}\right)\end{array}$ & $\begin{array}{c}\text { Cum. } \\
\text { Volume } \\
\left(\mathrm{km}^{3}\right)\end{array}$ & $\begin{array}{l}\text { Group Cum. } \\
\text { Volume } \\
\left(\mathbf{k m}^{3}\right)\end{array}$ & $\begin{array}{c}\text { Avg. Thickness } \\
\text { (m) }\end{array}$ \\
\hline Pitchstone Plateau & $79 \pm 11$ & & 351 & 70 & 366 & & 200 \\
\hline Grants Pass & $72 \pm 3$ & $76 \pm 5$ & 14 & 0.5 & 296 & 71 & 37 \\
\hline Solfatara Plateau & $103 \pm 8$ & & 123 & 7 & 295 & & 57 \\
\hline Hayden Valley & $102 \pm 4$ & $103 \pm 1$ & 111 & 2 & 288 & 9 & 17 \\
\hline West Yellowstone & $114 \pm 1$ & & 389 & 41 & 286 & & 105 \\
\hline Trischman Knob & & & 0.8 & 0.014 & 245 & & 17 \\
\hline Douglas Knob & & & 0.3 & 0.010 & 245 & & 32 \\
\hline Bechler River & $116 \pm 2$ & & 236 & 8 & 245 & & 35 \\
\hline Summit Lake & $124 \pm 10$ & $118 \pm 5$ & 402 & 37 & 237 & 86 & 92 \\
\hline Cold Mountain Creek & $143 \pm 5$ & & & $10^{*}$ & 200 & & \\
\hline Spring Creek & & & 115 & 7 & 190 & & 63 \\
\hline Nez Perce Creek & $148 \pm 5$ & & 157 & 6 & 183 & & 41 \\
\hline Spruce Creek & & & 95 & 3 & 176 & & 32 \\
\hline Elephant Back & $153 \pm 2$ & & 325 & 25 & 173 & & 77 \\
\hline Aster Creek & $155 \pm 3$ & $150 \pm 5$ & 332 & 10 & 148 & 62 & 31 \\
\hline Buffalo Lake & $160 \pm 3$ & & 552 & 54 & 138 & & 97 \\
\hline Mary Lake & $165 \pm 4$ & & 33 & 2 & 84 & & 46 \\
\hline West Thumb & $173 \pm 11$ & & 245 & 11 & 83 & & 43 \\
\hline Bluff Point & $173 \pm 5$ & & & $50 *$ & 72 & & \\
\hline Dry Creek & $166 \pm 9$ & & 178 & 9 & 22 & & 53 \\
\hline Mallard Lake & $164 \pm 14$ & & 225 & 13 & 13 & 138 & 56 \\
\hline Unobserved units & & $167 \pm 5$ & 2985 & & 256 & 256 & 86 \\
\hline
\end{tabular}

Lava flows shown in most probable order of age, as based on data shown in figure 9. Cumulative volume of all flows excludes the estimated volume of unobserved older flows.

*Volumes for the two pyroclastic units cannot be calculated from existing data; the volumes shown with asterisks are rough estimates based only on the extents of known outcrop distributions and the size of the West Thumb caldera, source of the tuff of Bluff Point, as noted in the text. 
Table 3. Large hydrothermal explosion craters in Yellowstone National Park (data from Muffler and others, 1971; Morgan and others, in review).

\begin{tabular}{|c|c|c|c|c|c|c|c|c|c|}
\hline Feature & $\begin{array}{l}\text { Max.. } \\
\text { length } \\
\text { (m) }\end{array}$ & $\begin{array}{l}\text { Max.. } \\
\text { width* } \\
\text { (m) }\end{array}$ & $\begin{array}{l}\text { Diameter } \\
\text { (avg.) } \\
\text { (km) }\end{array}$ & $\begin{array}{l}\text { Area } \\
\left(\mathrm{km}^{2}\right)\end{array}$ & $\begin{array}{l}\text { Max. } \\
\text { Rim } \\
\text { height } \\
\text { (m) }\end{array}$ & $\begin{array}{c}\text { Max. } \\
\text { water } \\
\text { depth } \\
\text { (m) }\end{array}$ & $\begin{array}{c}\text { Total } \\
\text { depth } \\
\text { rim to } \\
\text { floor } \\
\text { (m) }\end{array}$ & Geologic Setting & $\begin{array}{l}\text { Age (est.) } \\
\text { (ka) }\end{array}$ \\
\hline \multicolumn{10}{|l|}{ Norris-Mammoth corridor: } \\
\hline $\begin{array}{l}\text { Roaring Mountain east crater } \\
\text { complex }\end{array}$ & 644 & 504 & 0.574 & 0.255 & 58 & 0 & 58 & \multirow{3}{*}{$\begin{array}{l}\text { In Lava Creek Tuff (LCT), along Norris- } \\
\text { Mammoth corridor } \\
\text { In Lava Creek Tuff, along Norris-Mammoth } \\
\text { corridor } \\
\text { In Lava Creek Tuff, along Norris-Mammoth } \\
\text { corridor } \\
\text { In Lava Creek Tuff, along Norris-Mammoth } \\
\text { corridor }\end{array}$} & \\
\hline Roaring Mountain north crater & 314 & 289 & 0.302 & 0.071 & 33 & 0 & 33 & & $<16$ \\
\hline $\begin{array}{l}\text { The Gap-Norris Geyser Basin } \\
\text { Horseshoe Hill explosion crater }\end{array}$ & 114 & 105 & 0.162 & 0.009 & 16 & unknown & 16 & & $<16$ \\
\hline \multicolumn{10}{|l|}{ Lower and Upper Geyser Basins: } \\
\hline Pocket Basin & 758 & 418 & 0.588 & 0.249 & 41 & 0 & 41 & $\begin{array}{l}\text { In basin of Quaternary sediments surrounded by } \\
\text { rhyolite lavas } \\
\text { In basin of Quaternary sediments surrounded by }\end{array}$ & $<16$ \\
\hline Rush Lake & 342 & 240 & 0.291 & 0.064 & 23 & unknown & 23 & $\begin{array}{l}\text { rhyolite lavas } \\
\text { Thermal kame, in basin surrounded by rhyolite }\end{array}$ & $<16$ \\
\hline Twin Buttes & 641 & 624 & 0.633 & 0.314 & 129 & unknown & 129 & lavas & $<16$ \\
\hline \multicolumn{10}{|l|}{ West Thumb area: } \\
\hline Duck Lake & 733 & 500 & 0.617 & 0.288 & 35 & 18 & 53 & Edge of Dry Creek flow & $4-6$ \\
\hline Evil Twin & 553 & 544 & 0.549 & 0.236 & 27 & 42 & 27 & High heat flow, edge of Aster Creek flow & $4-6$ \\
\hline \multicolumn{10}{|c|}{ Northern and Central Yellowstone Lake area: } \\
\hline Turbid Lake & 1685 & 1502 & 1.594 & 1.988 & 85 & 42 & 127 & $\begin{array}{l}\text { In alluvium, along topographic margin } \\
\text { Yellowstone caldera } \\
\text { In alluvium, along Weasel Creek-Storm Point }\end{array}$ & 10.3 \\
\hline Indian Pond & 495 & 418 & 0.457 & 0.163 & 11 & 27 & 38 & linear trend & 3.0 \\
\hline Mary Bay & 2400 & 2824 & 2.612 & 5.323 & 60 & 53 & 113 & High heat flow region of Yellowstone Lake & 13.6 \\
\hline Elliott's crater & 938 & 727 & 0.833 & 0.536 & 52 & 60 & 52 & $\begin{array}{l}\text { High heat flow, inside edge of lava flow } \\
\text { Edge Aster Creek flow, topo. margin }\end{array}$ & 8.0 \\
\hline Frank Island crater & 770 & 712 & 0.741 & 0.431 & 21 & 50 & 21 & Yellowstone caldera & \\
\hline Upper Pelican river: & & & & & & & & & \\
\hline Sulphur Hills crater & 354 & 248 & 0.301 & 0.069 & 50 & 0 & 50 & Creek dome & $<16$ \\
\hline
\end{tabular}


Northeast Caldera area:

\section{Fern Lake}

Hot Spring Basin Group

Joseph's Coat

*Maximum width is measured perpendicular to maximum length.
Edge Upper Basin Member near topo. margin

Yellowstone caldera

LCT and thermal kame, along topo. margin

Yellowstone caldera

Thermal kame, edge Canyon Flow \& topo. margin Yell. caldera 
Table 4. Some historic hydrothermal explosion craters in Yellowstone National Park.

\begin{tabular}{|c|c|c|c|c|c|}
\hline Feature & Thermal area & $\begin{array}{l}\text { Maximum } \\
\text { length } \\
(\mathrm{m})\end{array}$ & $\begin{array}{l}\text { Maximum } \\
\text { width } \\
\text { (m) }\end{array}$ & $\begin{array}{c}\text { Age } \\
\text { (estimated) }\end{array}$ & Reference \\
\hline \multicolumn{6}{|l|}{ Upper Geyser Basin } \\
\hline Link Geyser & Biscuit Basin & n.d. & n.d. & $1957-1958$ & (Marler and White, 1975) \\
\hline Black Opal/Wall Pool & Biscuit Basin & 60 & 15 & $\begin{array}{l}1918,1925 \\
1934,1953\end{array}$ & (Marler and White, 1975; Paperiello, 1998) \\
\hline Sapphire & Biscuit Basin & 10 & 6 & 1959 & (Marler and White, 1975) \\
\hline Biscuit (2 small geysers) & Biscuit Basin & n.d. & n.d. & 1963 & (Marler and White, 1975) \\
\hline Seismic Geyser & Cascade Group & 12 & & 1959-1971 & (Marler and White, 1975) \\
\hline near Sponge geyser & Geyser Hill & n.d. & n.d. & 1969 & (Marler and White, 1975) \\
\hline Plume Geyser & Geyser Hill & n.d. & n.d. & 1922,1972 & (Marler, 1973) \\
\hline \multicolumn{6}{|c|}{ Lower and Midway Geyser Basins } \\
\hline FCG-3 of Bryan (1995) & Fairy Group & 3 & 3 & $1980 ?$ & (Bryan, 1995) \\
\hline e. shoulder of Spasm geyser & Fountain Group & 1.5 & 1.2 & 1969 & (Marler and White, 1975) \\
\hline S. Side White Creek & Fountain Lake & n.d. & n.d. & 1959 & (Marler and White, 1975) \\
\hline Blowout Spring & Kaleidoscope Group & 4.5 & 4.5 & 1959 & (Marler, 1973) \\
\hline 18 m. north Kaleidoscope geyser & Kaleidoscope Group & 3 & 3 & 1963 & (Marler and White, 1975) \\
\hline E. Shoulder of Honeycomb & Kaleidoscope Group & 3.7 & 1.8 & 1960 & (Marler and White, 1975) \\
\hline West Flood Geyser & Midway Geyser Basin & 10.5 & 9 & btw 1904-1940 & (Marler and White, 1975) \\
\hline Excelsior & Midway Geyser Basin & 107 & 55 & $\begin{array}{l}1881,1882 \\
1888,1890\end{array}$ & (Whittlesey, 1990) \\
\hline \multicolumn{6}{|l|}{ Norris Geyser Basin } \\
\hline Porcelain Terrace & Norris Geyser Basin & 9 & 2 & 1971 & (White and others, 1988) \\
\hline Nymph Lake & Norris Geyser Basin & 75 & 21 & 2003 & http://volcanoes.usgs.gov/yvo/2003/NorrisTherm03.html \\
\hline Porkchop & Norris Geyser Basin & 13.9 & 11.7 & 1989 & (Fournier and others, 1991) \\
\hline Area $3 \mathrm{~km}$ northwest of Norris & Unnamed & 16 & 11 & 1986,1987 & (Hutchinson, 1987; Hobart, 1989) \\
\hline Unnamed & $\begin{array}{l}\text { Thermal area west of Elk } \\
\text { Park }\end{array}$ & n.d. & n.d. & 1988 & (Paperiello, 1998) \\
\hline \multicolumn{6}{|l|}{ Other Areas } \\
\hline Unnamed & Mushpots & 1.9 & 1.4 & 1985 & (Hutchinson, 1990) \\
\hline $\begin{array}{l}\text { Unnamed vent } 1 \mathrm{~km} \mathrm{~S} \text { of Lone } \\
\text { Star }\end{array}$ & Divide Group & 1 & 1 & 1999 or 2000 & Jeff Cross (personal commun., Feb. 2004) \\
\hline Blowout Pool & Shoshone Geyser Basin & 5 & 5 & 1929 & (Davis, 1930) \\
\hline Explosion Pool & Potts Basin & n.d. & n.d. & 1965,1982 & (Taylor and Grigg, 1999) \\
\hline 60 North & Potts Basin & n.d. & n.d. & 1998 & (Taylor and Grigg, 1999) \\
\hline Semicentennial & Roaring Mountain & n.d. & n.d. & 1922 & (Whittlesey, 1988) \\
\hline
\end{tabular}

n.d. No data 
Table 5. Estimates of annualized probability of events greater than a given magnitude.

$\begin{array}{cccc}\text { Diameter }(\mathbf{m}) & \text { Area }\left(\mathbf{m}^{2}\right) & \begin{array}{c}\text { Events in last 14 } \\ \text { thousand years }\end{array} & \begin{array}{c}\text { Annualized } \\ \text { Probability }\end{array} \\ >2 & 3.1 & 7000 \text { (estimated) } & 0.50 \\ >300 & 70,700 & 16 & 0.0013 \\ >2000 & 3,140,000 & 2 & 0.00014\end{array}$


Table 6. Ages of late intracaldera lavas and tuffs. Group ages for episodes calculated from the means and standard deviations of the nominal ages. Model I arbitrarily spreads individual events for each episode over 1000-year time intervals. Model II spreads individual events over plus and minus one standard deviation for the three oldest episodes and, for the two youngest episodes (each with only two events), at the event age and one standard deviation. Model III is an estimated chronology based as closely as possible on the nominal ages and analytical standard deviations of the individual events.

\begin{tabular}{|c|c|c|c|c|c|c|}
\hline No. & Name & Ages and sd (ka) & $\begin{array}{c}\text { Group mean age } \\
\text { and sd (ka) }\end{array}$ & $\begin{array}{l}\text { Model I age } \\
\text { (ka) }\end{array}$ & $\begin{array}{c}\text { Model II age } \\
\text { (ka) }\end{array}$ & $\begin{array}{c}\text { Model III age } \\
\text { (ka) }\end{array}$ \\
\hline 1 & Pitchstone Plateau & $79 \pm 11$ & \multirow{2}{*}{$76 \pm 5$} & 72 & 72 & 72 \\
\hline 2 & Grants Pass & $72 \pm 3$ & & 73 & 76 & 73 \\
\hline 3 & Solfatara Plateau & $103 \pm 8$ & \multirow{2}{*}{$103 \pm 1$} & 102 & 102 & 102 \\
\hline 4 & Hayden Valley & $102 \pm 4$ & & 103 & 107 & 103 \\
\hline 5 & West Yellowstone & $114 \pm 1$ & \multirow{5}{*}{$118 \pm 5$} & 113.5 & 112 & 114 \\
\hline 6 & Trischman Knob & & & 113.8 & 113 & 116 \\
\hline 7 & Douglas Knob & & & 114 & 114 & 116.2 \\
\hline 8 & Bechler River & $116 \pm 2$ & & 114.3 & 115 & 116.4 \\
\hline 9 & Summit Lake & $124 \pm 10$ & & 114.5 & 116 & 124 \\
\hline 10 & Cold Mountain Creek & $143 \pm 5$ & \multirow{6}{*}{$150 \pm 5$} & 151.5 & 149 & 143 \\
\hline 11 & Spring Creek & & & 151.7 & 150 & 145 \\
\hline 12 & Nez Perce Creek & $148 \pm 5$ & & 151.9 & 152 & 148 \\
\hline 13 & Spruce Creek & & & 152.1 & 153 & 150 \\
\hline 14 & Elephant Back & $153 \pm 2$ & & 152.3 & 154 & 153 \\
\hline 15 & Aster Creek & $155 \pm 3$ & & 152.5 & 155 & 155 \\
\hline 16 & Buffalo Lake & $160 \pm 3$ & \multirow{7}{*}{$167 \pm 5$} & 163.5 & 159 & 160 \\
\hline 17 & Mary Lake & $165 \pm 4$ & & 163.7 & 161 & 165 \\
\hline 18 & West Thumb & $173 \pm 11$ & & 163.9 & 163 & 172 \\
\hline 19 & Bluff Point & $173 \pm 5$ & & 164.1 & 165 & 173 \\
\hline 20 & Dry Creek & $166 \pm 9$ & & 164.3 & 167 & 174 \\
\hline 21 & Mallard Lake & $164 \pm 14$ & & 164.5 & 169 & 175 \\
\hline 22 & Unobserved units & & & 165 & 171 & 176 \\
\hline
\end{tabular}


Table 7. Conditional probabilities for an eruption in the next year for Models I, II, and III for the mixed-exponential and Weibull distributions.

Mixed-exponential distribution

\begin{tabular}{|c|c|c|c|c|}
\hline $\begin{array}{c}\text { Time since last } \\
\text { eruption (y) }\end{array}$ & 0 & 1000 & 20000 & 72000 \\
\hline \multicolumn{5}{|l|}{ Model } \\
\hline I & $2.5 \times 10^{-3}$ & $5.6 \times 10^{-4}$ & $4.6 \times 10^{-5}$ & $4.6 \times 10^{-5}$ \\
\hline II & $4.3 \times 10^{-4}$ & $4.1 \times 10^{-4}$ & $3.5 \times 10^{-5}$ & $3.4 \times 10^{-5}$ \\
\hline III & $3.5 \times 10^{-4}$ & $3.3 \times 10^{-4}$ & $5.3 \times 10^{-5}$ & $5.1 \times 10^{-5}$ \\
\hline & \multicolumn{4}{|c|}{ Weibull distribution } \\
\hline $\begin{array}{c}\text { Time since last } \\
\text { eruption (y) }\end{array}$ & 0 & 1000 & 20000 & 72000 \\
\hline \multicolumn{5}{|l|}{ Model } \\
\hline I & $2.5 \times 10^{-2}$ & $3.5 \times 10^{-4}$ & $7.5 \times 10^{-5}$ & $3.9 \times 10^{-5}$ \\
\hline II & $3.3 \times 10^{-4}$ & $2.4 \times 10^{-4}$ & $2.2 \times 10^{-4}$ & $2.1 \times 10^{-4}$ \\
\hline III & $4.7 \times 10^{-4}$ & $2.4 \times 10^{-4}$ & $1.9 \times 10^{-4}$ & $1.7 \times 10^{-4}$ \\
\hline
\end{tabular}




\section{Appendices}

\section{Appendix 1. Description of representative historic hydrothermal explosions}

\section{Porkchop Spring/Geyser}

The most carefully documented hydrothermal explosion at Yellowstone occurred in 1989 at Porkchop Geyser in Norris Geyser Basin. The following description is summarized from Fournier and others (1991).

Prior to 1985, Porkchop Geyser was a relatively obscure 3-m-long pool with a triangular orifice at the surface, a few $\mathrm{cm}$ on each side. In 1985, a change occurred wherein the pool drained and was replaced by a 6- to 9-m-high "perpetual spouter" with continual pulsing of fluid. For four years, such behavior continued, with sufficient discharge to produce a roar audible up to $2 \mathrm{~km}$ away from the vent. At 14:40 MDT on September 5, 1989, eight park visitors witnessed a tripling of the eruption column height, immediately followed by explosive disruption and ejection of the sinter sheet surrounding the pool; the explosion was over in seconds. It resulted in formation of an 11-mwide pool surrounded by an ejecta ring of sinter that was between 1 and 1.4 meters high. Material was ejected as far away from the pool as 66 meters to the south. The debris was not dispersed evenly as materials traveled only about 25 meters eastward. The maximum diameter of the largest ejected block measured 1.9 meters. Fournier and others (1991) interpreted breccia blocks in the ejected sinter as evidence of earlier explosions. In addition, a fluted fragment appeared to be part of the throat (or conduit) of the geyser. The throat was at least $10 \mathrm{~cm}$ in diameter, considerably greater than the size of the orifice through which Porkchop had been venting to the surface.

\section{Excelsior Geyser}

The most witnessed, and most impressive of all historic hydrothermal explosions at Yellowstone took place over about ten years between 1881 and 1890 at Excelsior Geyser in the Midway Geyser Basin. These explosions highlight the continuum between geyser eruptions and hydrothermal explosions. In essence, Excelsior exhibited geysering that was sufficiently intense that rock fragments were commonly ejected and the size of the crater was markedly enlarged. One hundred years after the cessation of its phenomenal geysering, Lee Whittlesey, the Yellowstone National Park historian and archivist summarized the eyewitness accounts of the Excelsior eruptions (Whittlesey, 1990). The following material summarizes that information.

Excelsior was already a large and active 60 x 100 meter spring when the park was discovered in 1872. Though eruptive activity may have started earlier, it was first described in 1881, jetting to heights of 30 to 90 meters and, according to Superintendent P. W. Norris, sufficiently exceeding the activity of any other geyser that it merited the title of Excelsior. Activity continued into 1882, with occasional eruptions over 110 meters in height. Whittlesey (1990) quotes tour guide Nestor Henderson:

"The close of each eruption was accompanied by violent earthquake shocks that tore down the geyserite walls and added much both to the danger and [to the] sublimity of the spectacle. These masses of broken wall were at each eruption hurled into the air several hundred feet above the topmost waves, clashing together in their descent into the yawning abyss with a deafening noise that was most terrific." 
By the Fall of 1882, Excelsior became dormant. It may have erupted between 1883 and 1888 , but is clearly documented to have returned to activity by May 1,1888 , when blocks $0.3 \mathrm{~m}$ in diameter were hurled over $150 \mathrm{~m}$ from the crater. Eruptive activity continued throughout the summer and fall. The last known eruption is believed to have been in 1890, until Excelsior erupted again for two days in 1985, over one hundred years after its first described eruptions.

Water discharge from Excelsior's larger eruptions is said to have doubled the outflow of the Firehole River. The plume from Excelsior was visible at distances up to $160 \mathrm{~km}$ because the steam from its eruptions would create its own clouds.

\section{West Nymph Creek Thermal Area}

The West Nymph Creek Thermal Area is an informal name for the unnamed backcountry thermal area approximately $3 \mathrm{~km}$ north-northwest of the Norris Geyser Basin. The area was the site of a series of hydrothermal explosions during 1987. In June, some time after activity had started, two park employees witnessed a vent ejecting mud as high as six meters and as far away as ten meters from the crater rim. As discussed in Hutchinson (1987), bursts from the pool were "churning freshly-killed tree trunks as if they were oversized swizzle sticks." The crater size was $9.1 \times 10.5 \mathrm{~m}$, with a depth as great as $3.45 \mathrm{~m}$. This crater was 27 meters downslope from another crater inferred to have formed on January 26, 1986 as an effect of the autumn 1985 seismic swarm, in the northwest part of the Yellowstone caldera. Several other older but similar craters are found within this thermal area. A report from a snow-coach driver combined with on-site observations led the park geologist to conclude that the 1986 event was over in a matter of a few hours.

\section{Black Opal/Wall Pool and Sapphire Pool}

Explosions that created the present Black Opal Pool and Wall Pool in the Upper Geyser Basin may have begun as early as 1902, but are clearly documented in 1918, 1925, 1934 and 1953. By 1934, the opening of what is today "Wall Pool" was essentially complete. Subsequent activity was entirely at Black Opal Pool. In January of 1934, a violent explosion created a pool $12 \mathrm{~m}$ in diameter that had not existed a week before. Several tons of rock were displaced, and some $300 \mathrm{~kg}$ rocks had been transported $9 \mathrm{~m}$ (Paperiello, 1998).

As noted above, explosive activity occurred in other years as well, and into the 1950s. After the August 17, 1959 Hebgen Lake earthquake, Black Opal Pool remained quiet, but nearby Sapphire Pool exhibited impressive changes. For about three weeks after the earthquake, it surged constantly to a height of 3-4 meters. On September 5, massive bursts up to $\sim 50 \mathrm{~m}$ from an area about $60 \mathrm{~m}$ across began a period of activity that washed away the famous silica biscuits for which Biscuit Basin was named (Marler, 1964).

\section{Historic hydrothermal explosions elsewhere}

On April 19, 2005, a 50m-wide crater resulted from a hydrothermal eruption in a remote area of New Zealand between Taupo and Rotorua. Mud and water were dispersed 70-100 meters away from the site, and the eruptive column, which reached 200 meters into the air, was visible from $10 \mathrm{~km}$ away. The eruption was one of many that have occurred over the past 40 years in New Zealand. In 2000-2005 alone, eight different events were reported for New Zealand in the Bulletin of the Global Volcanism Network (http://www.volcano.si.edu). Scott and Cody (2000) reported that 91 hydrothermal explosions of natural features had occurred in Rotorua city between 1845 and 1998, with the majority occurring at times of greatest human impact on the local hydrology and geothermal systems.

In October 1990, a thermal area near El Barro, El Salvador exploded without apparent warning, killing 25 people and injuring 15 . The area was within a small community adjacent to the 
producing Ahuachapán geothermal field. The eruption lasted a few minutes, created a crater $40 \mathrm{~m}$ in diameter and dispersed rock fragments over a 200-m-diameter area (Handal and Barrios, 2004). Historical and geological studies indicate that the area had experienced previous hydrothermal explosions.

\section{Appendix 2. Description of large prehistoric hydrothermal eruption sites at Yellowstone}

\section{Pocket Basin}

Muffler and others (1971) were the first to describe hydrothermal-explosion craters in Yellowstone National Park, focusing primarily on Pocket Basin, a late Pleistocene ring of fragmental deposits within the Lower Geyser Basin. Their study describes Pocket Basin as a flatfloored basin surrounded by an elliptical ridge of rock 360 x $790 \mathrm{~m}$ in minimum and maximum diameters. The height of the ridge above the basin floor ranges from 4 to $20 \mathrm{~m}$, with the inner slopes as steep as 20 to $25^{\circ}$ and the shallower outer slopes less than $10^{\circ}$. The ridge is composed of unconsolidated and unsorted materials that are predominantly angular fragments of yellow-stained sandstone, siltstone and conglomerates. Most blocks in the deposit are less than $0.3 \mathrm{~m}$ in diameter, though a few range up to $2.5 \mathrm{~m}$. The deposits are apparently only from shallow sources as only clasts from glacial deposits are present, with none of the underlying rhyolitic lava that was encountered at depths of 40 meters in a nearby drillhole (Y3). Ejecta fragments are found as far as 1200 meters from the center of Pocket Basin, and thus much farther than the actual berm of eruption deposits. The presence of glacial ice in the adjacent basin was inferred by Muffler and others (1971) as an explanation for incision of the Firehole River through the Pocket Basin deposits rather than adjacent lowlands. This helps constrain the time of eruption to that of the latest glaciation, which ended $\sim 16 \mathrm{ka}$. These authors speculated that catastrophic release of water from a glacial lake overlying areas within the Lower Geyser Basin may have caused an abrupt pressure decrease within the geothermal system, thus triggering the eruption.

\section{Mary Bay}

In the northern basin of Yellowstone Lake, Mary Bay contains an approximately 2.4-km by 2.8-km area of coalesced explosion craters (Wold and others, 1977), making it the world's largest known hydrothermal-explosion crater (Browne and Lawless, 2001). The Mary Bay hydrothermalexplosion crater extends from the northern basin of Yellowstone Lake onto land and into the lower Pelican Valley where steep ( $\sim 35^{\circ}$ slope) cliffs of explosion breccia are exposed. In the lake, a welldefined crater rim on the lake floor rises about $10 \mathrm{~m}$ above the flat-bottomed crater; the total elevation difference between the flat-bottomed main crater floor to the top of the outer, subaerial crater rim is as much as $70 \mathrm{~m}$ (Morgan and others, 2003b; Morgan and others, in review). About 100 individual hydrothermal-vent structures are located within the larger main crater; individual vents are as deep as $35 \mathrm{~m}$ below the main crater floor, making the total elevation difference from bottom of an individual vent to the top of the rim close to $105 \mathrm{~m}$. Investigations using a submersible Remotely Operated Vehicle (ROV) show that fluids from a narrow, 53-m-deep hydrothermal vent in Mary Bay have temperatures near the $120^{\circ} \mathrm{C}$ limit of the temperature probes used, reflecting extremely high heat-flow values in this area (Morgan and others, 1977). Charcoal fragments collected from the soil layer below the Mary Bay ejecta deposits as well as from within the hydrothermal explosion deposit have an average calibrated ${ }^{14} \mathrm{C}$ age of $13.6 \mathrm{ka} \mathrm{BP}$ (Pierce and others, 2002). 


\section{Elliott's crater}

Within Yellowstone Lake, 1 kilometer southwest of the Mary Bay crater complex is a large ( 800-m-diameter) composite depression informally referred to as Elliott's crater (Morgan and others, 2003b), named after Henry Elliott, who mapped Yellowstone Lake during the 1871 Hayden survey. The northern rim of the crater rises about $40 \mathrm{~m}$ above the flat-bottomed main crater floor, whereas the southern crater rim is about $30 \mathrm{~m}$ above the crater floor. About 10 smaller individual craters are present on the main crater floor and along the southwest rim; several of these are active and have fluid temperatures ranging from $51^{\circ} \mathrm{C}$ to as high as $91^{\circ} \mathrm{C}$. The presence of two younger craters at the south end of the main crater floor and the presence of many smaller hydrothermal vents further indicates more recent hydrothermal activity and possibly younger explosions. Along the southeast and eastern rim outside of the main crater, more than $3 \mathrm{~km}$ south from shore, rocks of varied lithologic compositions lie above sediments on the lake floor; these rocks may be products of more recent hydrothermal explosions.

Stratigraphic relations indicate that the main hydrothermal explosion occurred between 13 and $8 \mathrm{ka}$, based on sedimentation rates in the lake (Johnson and others, 2003). Seismic reflection techniques identify "opaque areas" within the sedimentary fill that are interpreted to indicate the presence of hydrothermal fluids and (or) gases (Johnson and others, 2003; Morgan and others, 2003b).

\section{Evil Twin explosion crater}

Morgan and others (2003b) described a 500-m-diameter, sublacustrine explosion crater, referred to informally as the Evil Twin explosion crater, in the western part of West Thumb basin near the currently active West Thumb Geyser Basin and 300 m northeast of Duck Lake, a postglacial (subaerial) hydrothermal-explosion crater just outside Yellowstone Lake (Muffler and others, 1971). The 500-m-wide Evil Twin explosion crater is surrounded by 12- to 20-m-high, nearly vertical, walls and has several smaller nested craters along its eastern edge. These nested craters are as deep as $40 \mathrm{~m}$ and are younger than the main crater. Temperatures of hydrothermal fluids emanating from the smaller northeastern nested crater have been measured at $72^{\circ} \mathrm{C}$ by $\mathrm{ROV}$ (Morgan and others, in review).

\section{Frank Island explosion crater}

An oval, steep-walled, flat-bottomed hydrothermal-explosion crater more than $700 \mathrm{~m}$ wide is located south of Frank Island (Morgan and others, 2003b). Previous lower-resolution seismic reflection profiles interpreted this structure as a topographic edge to the Yellowstone caldera (Otis and others, 1977); however, higher-resolution swath sonar and shallower seismic-reflection profiles indicate that this structure, while on the slumped margin of the Yellowstone caldera, has characteristics very similar to those of other hydrothermal explosion craters in Yellowstone Lake (Morgan and others, 2003b). Muted topography suggests that this explosion crater is one of the oldest still recognizable in Yellowstone Lake. Further, this crater occurs in an area where heat-flow values are, at present, relatively low. Submersible ROV investigations do not indicate hydrothermal activity within the crater (Morgan and others, in review).

\section{Indian Pond}

Indian Pond, formerly referred to as Squaw Lake (Muffler and others, 1971), is an oval, 500-m-wide, lake-filled crater (Table 3; Figure 20). The pond is rimmed by an apron of explosion breccia that rises about $11 \mathrm{~m}$ above present-day lake level. Low-resolution bathymetric surveys of Indian Pond (Unpubl. Data, Yellowstone National Park, 1966) indicate the pond has steep inward- 
dipping slopes around its perimeter and has at least three elongate, east-west-trending basins on the crater floor. The average depth of the crater floor is about $13 \mathrm{~m}$ below lake level; depths of the individual basins or smaller craters range from 20 to $27 \mathrm{~m}$ below lake level. The lake is breached on its southwest edge where Little Indian Creek flows out of Indian Pond into northern Yellowstone Lake.

The Indian Pond explosion breccia is a poorly sorted, matrix-supported breccia deposit; the matrix is light medium-brown clay that has a pervasive orange-yellow stain where groundwater has flowed. Lithic clasts in the breccia are generally angular to sub-angular and are composed primarily of cemented beach gravels with subordinate angular clasts of silicified lake sediments with hydrothermal clinoptilolite and well-sorted, fine-grained indurated golden-tan siltstone. Maximum diameter lithic fragments of cemented beach gravels and sands are up to $1.5 \mathrm{~m}$ at the crater rim; in the wave-cut terrace exposures along Mary Bay, lithic fragments have maximum diameters of $30 \mathrm{~cm}$ and average around 3 to $7 \mathrm{~cm}$. The thickness of the Indian Pond breccia in the wave cut terraces along Mary Bay is less than one meter, although northwest of the crater, thicknesses are estimated to be as much as several meters.

\section{Turbid Lake}

Turbid Lake, along the eastern edge of the topographic margin of the Yellowstone caldera was recognized by Muffler and others (1971) as a hydrothermal explosion crater. It is the second largest hydrothermal explosion crater in Yellowstone, having a maximum crater diameter of 1685 meters and an area close to $2.0 \mathrm{~km}^{2}$ (Morgan and others, in review). A large primary crater is located in the main central portion of the lake and is rimmed by an apron of explosion breccia that rises about $33 \mathrm{~m}$ above present-day lake level on its northern, western, and southern shores. Along its eastern edge, evidence for a smaller second crater is present where a north-south-trending ridge of explosion breccia is deposited inside the main crater wall. The height of the eastern main crater wall rises about $85 \mathrm{~m}$ above present-day level of Turbid Lake. Low-resolution bathymetric surveys of Turbid Lake (Unpubl. data, Yellowstone National Park, 1977) indicate that the lake has steep inward-dipping slopes around its central deep crater and has multiple smaller craters around the periphery of the deep crater. Maximum depth of the central deep crater is $42 \mathrm{~m}$ below lake level; depths of the smaller craters range from $17 \mathrm{~m}$ to $5 \mathrm{~m}$ along the northern and western edges to as deep as $27 \mathrm{~m}$ along the eastern edge (table 3, Morgan and others, in review). The crater rim is breached on the north by the Sedge Creek inlet and on the south by the inlet of Bear Creek. At its western crater rim, Sedge Creek flows out of Turbid Lake and into northern Yellowstone Lake. Acidic hot springs are present along the eastern and southeastern rim; a thermal area is present along the southern rim at lake level. Mud pots there have $\mathrm{pH}$ of 1.1-1.5 and temperatures of 49$57^{\circ} \mathrm{C}$.

The hydrothermal breccia is exposed along the creeks, varying in thickness from 2 to $10 \mathrm{~m}$. The matrix-supported breccia is composed of angular fragments of hydrothermally altered Lava Creek Tuff, cemented gravels and sands, moderately and poorly sorted clastic sulfidic sandstones, cemented pebble conglomerate, and chert breccias (Morgan and others, in review). The matrix is generally whitish fine-grained clay. As noted by Muffler and others (1971), a broad constructional outer ramp extends from Turbid Lake toward the northwest and may be indicative of the primary flow direction of the explosion deposit. The explosion breccia may be distributed toward the northwest and west as much as $4.5 \mathrm{~km}$ from its source. Charcoal fragments from within the hydrothermal explosion deposit from the southern rim have a radiometric age of $9.4 \mathrm{ka}$ (Pierce and others, 2002). 


\title{
Appendix 3. Probabilities of episodic volcanic eruptions and application to the young intracaldera volcanic history of Yellowstone
}

\author{
By Manuel Nathenson and Robert L. Christiansen
}

An underlying assumption of USGS volcano hazards assessments for Cascade volcanoes in Oregon and Washington has been that the probability distribution of volcanic eruptions may be treated as a Poisson process. Time histories for some volcanoes match this assumption well (e.g. Klein, 1982). The probability of an eruption during any particular period of time is calculated from the relation for the occurrence rate. For a Poisson process, this relation is obtained from the exponential distribution for the probability $P\{T \leq t\}$ that an eruption will occur in a time $T$ less than or equal to the time period $t$ :

$$
\begin{aligned}
P\{T \leq t\}=F(t) & =1-\mathrm{e}^{-\mu t} \\
& \approx \mu t, \quad \text { for } \mu t \text { small, }
\end{aligned}
$$

where $\mathrm{F}(\mathrm{t})$ is the probability distribution function, and $\mu$ is the mean occurrence rate (events per year) for the exponential distribution. Investigators such as Scott and others (1995) cite low occurrence rates in the Cascades as justification for use of this relation there.

Given a set of $n$ eruption time intervals $t_{i}$, the average recurrence interval (the reciprocal of the occurrence rate) may be estimated by:

$$
\frac{1}{\mu}=\frac{1}{n} \sum_{i=1}^{n} t_{i}
$$

The properties of a Poisson process include the characteristic that the conditional probability of waiting a time until an eruption occurs does not depend on the time already waited but only on the time period selected (e.g. 1 year, 30 years, etc.) to calculate a conditional probability. For some volcanoes, the time history contains disparate time intervals between eruptions, some being short and others much longer. Some examples of time histories having such disparate eruption-time intervals are those of Mount Rainier and Mount St. Helens in Washington. Mullineaux's (1974) data for tephra layers at Mount Rainier include three long intervals (>2000 years) and seven short intervals (<600years) between eruptions. Mullineaux's (1996) data for Mount St. Helens include one interval of 8600 years, one of 1500 years, and 34 less than 640 years. In such instances, other probability distributions more accurately represent the data, the conditional probabilities based on these distributions depending on the time since the last eruption.

Bebbington and Lai (1996) proposed using the Weibull distribution to model eruption times that vary with the preceding time interval:

$$
\begin{aligned}
& P\{T \leq t\}=F(t)=1-\mathrm{e}^{-\mu(t)} \\
& \text { where } \mu(t)=\left(\frac{t}{\theta}\right)^{\beta}
\end{aligned}
$$

and $T$ is the time, less than the time period $t$, when an eruption will occur. Parameters $\theta$ and $\beta$ are referred to as the scale and shape parameters, respectively; when $\beta=1$, this reduces to the exponential distribution.

For eruption intervals that can be divided into two populations, one of short intervals and one of long intervals, a relevant model is the mixed exponential (Cox and Lewis, 1966; Nathenson, 2001):

$$
\begin{aligned}
& P\{T \leq t\}=F(t)=1-p_{1} \mathrm{e}^{-\mu_{1} t}-p_{2} \mathrm{e}^{-\mu_{2} t} \\
& \text { where } p_{1}=\frac{n_{1}}{n_{1}+n_{2}}
\end{aligned}
$$




$$
\text { and } \frac{1}{\mu_{1}}=\frac{1}{n_{1}} \sum_{i=1}^{n_{1}} t_{i}
$$

where $p_{1}$ is the fraction of short intervals, $\mu_{1}$ is the mean occurrence rate for the short intervals, $n_{1}$ is the number of short intervals, and $p_{2}, \mu_{2}$, and $n_{2}$ are equivalent parameters for the long intervals. The basic notion embodied in the mixed exponential is that there are two states. The probability of an eruption occurring in each of these states is governed by an exponential distribution. If one knew that the volcano were currently in a particular state (a difficult judgment to make), then the probability of an eruption could be calculated using the appropriate simple exponential relation for that state only.

Of direct interest for application here is the conditional probability $P\{\Delta t \leq T \leq t+\Delta t|T\rangle$ $\Delta t$ ) of an eruption occurring between time $\Delta t$ and time $t+\Delta t$, (e.g. the next year or the next 30 years), after already waiting a time $\Delta t$ since the last eruption. This conditional probability can be calculated from the distribution function $F(t)$ as

$$
P\{\Delta t \leq T \leq t+\Delta t \mid T>\Delta t\}=1-\frac{1-F(t+\Delta t)}{1-F(\Delta t)}
$$

For the simple exponential distribution, the conditional probability reduces to:

$$
P\{\Delta t \leq T \leq t+\Delta t \mid T>\Delta t\}=1-\mathrm{e}^{-\mu t}
$$

Thus, for the simple exponential distribution, the passage of past time does not change the probability of the time to a future eruption. (In the engineering language of time to failure, there is no wear or fatigue). For the Weibull distribution, the conditional probability is:

$$
P\{\Delta t \leq T \leq t+\Delta t \mid T>\Delta t\}=1-\exp \left\{\left(\frac{\Delta t}{\theta}\right)^{\beta}-\left(\frac{t+\Delta t}{\theta}\right)^{\beta}\right\}
$$

For the mixed exponential, the conditional probability is:

$$
\begin{aligned}
& P\{\Delta t \leq T \leq t+\Delta t \mid T>\Delta t\}=1-\left[p_{1} \mathrm{e}^{-\mu_{1}(t+\Delta t)}+p_{2} \mathrm{e}^{-\mu_{2}(t+\Delta t)}\right] / \\
& {\left[p_{1} \mathrm{e}^{-\mu_{1} \Delta t}+p_{2} \mathrm{e}^{-\mu_{2} \Delta t}\right]}
\end{aligned}
$$

Thus, unlike for the simple exponential distribution, the conditional probability for the mixed exponential does depend on the time since the last eruption, $\Delta t$.

As discussed in the section on hazards from large rhyolitic lava eruptions, the chronology of these eruptions is problematic. Table 6 reproduces the ages for these events as given in tables 1 and 2. Some of these rhyolites yield nominal ages that are younger that those of rhyolites that are stratigraphically above them, but all such discrepancies with stratigraphic order remain within the range of analytical uncertainty, reported as plus or minus one standard deviation. The combined record of mapped stratigraphy and isotopic ages suggests that these rhyolites represent a series of episodes. The times between episodes are tens of thousands of years, but the times between events within each episode are short—possibly tens, hundreds or a few thousand years. With available isotopic-age data, it is not possible to discern the actual time intervals between eruptions within an episode, and there could be intervals in one episode that are a few tens of years and in another episode that are hundreds or thousands of years. We use the available data to calculate both a mean age for each episode, weighted by the analytical uncertainty for each event within the episode, and a standard deviation for the age of the episode (table 6). The mean recurrence interval for the five episodes is $23 \mathrm{ky}$, with a range from $12 \mathrm{ky}$ to $38 \mathrm{ky}$; treating each episode as an independent event, the probability in one year of a new episode occurring is $4.3 \times 10^{-5}$.

To evaluate the variation in eruption probabilities resulting from the uncertainty of the various time intervals between eruptions within an episode, we assess three models. Model I assumes that each episode lasts a thousand years; the assumed individual eruption ages are spread evenly within that thousand years for each episode, as listed in table 6. Model II assumes that the 
calculated standard deviation for the mean age of each episode represents a measure, not only of the analytical uncertainty, but also the actual duration of the episode, spreading the individual events evenly over the calculated standard deviation. For the two youngest episodes, each with only two events, the age of one event in this model is taken to be the mean age, and the other is taken to be the mean age plus one standard deviation; for the other three episodes, the ages are spread over a time equal to plus and minus one standard deviation. Model III is an estimated chronology based as closely as possible on the reported ages and standard deviations for each eruptive event. When the nominal ages are in correct stratigraphic order, they are assigned directly. Other ages are assigned to be as close as possible to the nominal ages and both to be within the reported standard deviation and to comply with the proposed stratigraphic order. (For a few events, where stratigraphic order is ambiguous, as illustrated in figure 9, the order for model III is chosen rather than definitively established).

The three models tabulated in table 6 are illustrated in figure 27. Model I, with its short duration for each episode, readily resolves graphically into the five episodes discussed here. Model II, with its longer duration of each episode, still resolves graphically into the episodes but less clearly than model I. The episodes are not well resolved graphically in model III. Some of the episodes correspond graphically more to a change in rate of occurrence than to distinctly different times. All three models, however, preserve the observation that there are long periods with no intracaldera rhyolitic eruptive activity.

Probability distributions calculated for the three models (fig. 28) all show that most intervals are grouped at relatively short times and only a few at longer or much longer times. Model I (fig. 28A) has a large number of very short time intervals between eruptions and four longer intervals. Model II (fig. 28B) spreads the eruption time intervals more uniformly, with only two long intervals. Model III (fig. 28C) spreads the time intervals more uniformly than either of the other two models. The three analytical distribution functions are also shown for each model. As expected, because of the disparate time intervals, the simple exponential distribution is a poor fit to the data in models I and II, but it is a reasonable fit to the model III data. The Weibull distribution is a reasonably good fit to model I but a poor fit to both models II and III for the longinterval data. The mixed exponential distribution provides a good fit to both the short-interval and the long-interval data for each model.

The conditional probability of an eruption occurring in the next year is shown in figure 29 for each of the three models. Some representative values are listed in table 7, including some of the probabilities at short times after an eruption that are off the scale of the plots in figure 29 . The conditional probability based on the simple exponential distribution does not depend on the time since the last eruption. Because each of the three models has a somewhat different total duration, (table 6), the probabilities based on the exponential distribution vary slightly among the three parts of figure 29. The conditional probabilities based on the Weibull distribution for long times since the last eruption are considerably different for model I than for models II and III (fig. 29 and table 7). The mixed exponential distribution yields similar results for long times since the last eruption in all three models. Because of the poor match of the Weibull distribution for long time intervals with models II and III (fig. 28) and the variable results for the conditional probability at long times (fig. 29 and table 7), the mixed exponential distribution is a better choice for the calculation of conditional probabilities for this data set.

The greatest differences for conditional probabilities among the three models for the mixed exponential distribution are at short times. For the probability of an eruption in the next year immediately following an eruption, the mixed exponential distribution yields a probability almost ten times higher for model I than for models II and III (table 7). This result accords with the intuitive recognition that the many short time intervals in model I would lead one to anticipate another eruption shortly after one had occurred. At the present time, a value for the probability of 
an intracaldera rhyolitic eruption within the next year of $5 \times 10^{-5}$ reasonably represents all three models based on a mixed exponential distribution. This value is quite close to the value of $4 \times 10^{-5}$ calculated independently for a new episode. Because both calculations are model dependent, their very similar results are reassuring; it has been $\sim 72 \mathrm{ky}$ since the last eruption, which is also the time since the last episode. The major differences among the models are in the estimation of the probabilities of another eruption to follow if an eruption were to occur now (table 7). The limitations of the available data preclude a definitive resolution of those differences and heighten the uncertainty associated with their use in estimating eruption probabilities.

In addition to the probability of a future intracaldera rhyolitic eruption occurring within any given time period, an important consideration would be its likely size. Figure 30 illustrates the probability of a future lava eruption within the caldera having a volume greater that any particular value, based upon volumes estimated for 20 of the known late intracaldera eruptions (91\% of the known events), excluding the two pyroclastic eruptions, whose volumes are indeterminate (table 3 ). The data are distributed logarithmically with volume over most of the range. The probability that a future intracaldera lava flow would have a volume greater than $2 \mathrm{~km}^{3}$ is about $80 \%$; the probability of a volume greater than $10 \mathrm{~km}^{3}$ is about $40 \%$. Thus, the probability of a large-volume future lava flow in the caldera is greater than the probability of a small one. 